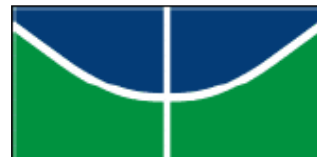 \\ UNIVERSIDADE DE BRASÍLIA
}

Decanato de Pesquisa e Pós-Graduação

Instituto de Ciências Biológicas

Instituto de Física

Instituto de Química

Faculdade UnB Planaltina

Programa de Pós-Graduação em Ensino de Ciências

Mestrado Profissional em Ensino de CiênCias

\section{A TRANSIÇÃO ENTRE OS NÍVEIS - MACROSCÓPICO, SUBMICROSCÓPICO E REPRESENTACIONAL - UMA PROPOSTA METODOLÓGICA}

Mayara Soares de Melo

Brasília - DF 


\section{$+1$ \\ UNIVERSIDADE DE BRASÍLIA}

Decanato de Pesquisa e Pós-Graduação

Instituto de Ciências Biológicas

Instituto de Física

Instituto de Química

Faculdade UnB Planaltina

Programa de Pós-Graduação em Ensino de Ciências

Mestrado Profissional em Ensino de CiênCias

\section{A TRANSIÇÃO ENTRE OS NÍVEIS - MACROSCÓPICO, SUBMICROSCÓPICO E REPRESENTACIONAL - UMA PROPOSTA METODOLÓGICA}

Mayara Soares de Melo

Dissertação elaborada sob orientação do Prof. Dr. Roberto Ribeiro da Silva apresentado à banca examinadora como requisito parcial à obtenção do Título de Mestre em Ensino de Ciências pelo Programa de PósGraduação em Ensino de Ciências da Universidade de Brasília.

\section{Brasília-DF}

Julho 



\section{FOLHA DE APROVAÇÃO}

Mayara Soares de Melo

"A transição entre os níveis - macroscópico, submicroscópico e representacional - uma proposta metodológica"

Dissertação apresentada à banca examinadora como requisito parcial à obtenção do Título de Mestre em Ensino de Ciências, pelo Programa de Pós-Graduação em Ensino de Ciências (PPGEC) da Universidade de Brasília (UnB).

Aprovada em 10 de julho de 2015.

BANCA EXAMINADORA

Prof. Dr. Roberto Ribeiro da Silva - IQ/UnB

(Presidente)

Prof. Dr. Eduardo Luiz Dias Cavalcanti - IQ/UnB

(Membro Titular)

Profa. Dra. Renata Cardoso de Sá Ribeiro Razuck - IQ/UnB

(Membro Titular)

Prof. Dr. Ricardo Gauche - IQ/UnB

(Membro Suplente) 
Para meus amores, Alan e Sophia, por darem um novo sentido à minha vida... Para todos os professores dedicados ao ofício de ensinar (e aprender) por levarem novas oportunidades para a vida de outros... 


\section{AGRADECIMENTOS}

Ao meu amor e melhor amigo Alan, que participou dos melhores momentos da minha vida acadêmica e pessoal, me apoiando e dando todo suporte necessário para que chegasse até aqui. Ele que sempre me consolou nos momentos mais difíceis e me fazendo rir quando mais precisava.

À Sophia, uma mocinha guerreira que aguentou todas as minhas faltas e, mesmo quando estávamos distantes, era dela que conseguia forças para continuar. Minha pequena menina que me fez ver o mundo de outra forma...

Agradeço ao meu pai João que sempre me deu o maior amor do mundo, se orgulhando de cada uma das minhas conquistas e é o centro de nossa família...

À minha mãe Celi que me ensinou a ler e a amar os livros, que foi (e ainda é) mãe duas vezes me ajudando na educação (e a deseducação também) de minha filha Sophia e que é um exemplo para mim. Ela que muitas vezes não entendeu minhas faltas (foram muitos "termina logo isso") e mesmo sem entende-las respeitou cada decisão por mim tomada.

À minha irmã e melhor amiga Danyella e meu cunhado Michel que estiveram presentes nos momentos de descontração e também me ajudaram nos cuidados com a minha filha... Além de agradecer aos meus dois presentes: João Gabriel e Letícia, que me dão muitas alegrias.

À minha sogra Elanir, meu sogro Paulo e meu cunhado Alexandre que são minha segunda família...

Aos amigos do Xaninani (Indy, Bié, Marília, André, Zorzo, Mayara, Tássia, Bola, Maurício, Paty, Peixe e Felis) que são os amigos mais incríveis do mundo, que me fazem sorrir sempre e estiveram presentes nos momentos mais importantes da minha vida.

Aos amigos do Ensino de Química, Verenna, com quem além de refletir sobre nossas pesquisas e futuro profissional, pude aprender a ser uma pessoa mais dedicada e mais centrada na busca por meus objetivos. Obrigada pelos momentos felizes nos congressos, pelos trabalhos juntas e pela amizade verdadeira... Eleandro, que me mostrou autores antes desconhecidos, trouxe novas perspectivas e oportunidades com a proveitosa experiência na docência para a licenciatura em Química. Obrigada por ser um grande parceiro... E Rafael que me recebeu tão bem em sua escola e me cedeu as aulas que precisava para aplicação da proposta...

Aos professores da licenciatura em Química da UnB, que foram essenciais para minha formação (e de tantos outros), me fazendo perceber que o Ensino de Química precisa melhorar e que eu posso contribuir um pouquinho para isso. À professora Renata e ao professor Eduardo pelas valiosas contribuições na apresentação do projeto e por aceitarem compor a banca de arguição. 
Ao professor Bob (em especial), que foi e sempre será um verdadeiro orientador, não só meu mas de todos os interessados em contribuir para melhorias no Ensino de Química no Brasil. Uma pessoa extremamente dedicada e comprometida no desenvolvimento de estratégias que tornem a Química mais interessante e favoreçam a compreensão dos estudantes. Nunca me esquecerei de sua alegria ao encontrar (ou aprender) algo novo e diferente para as aulas: um lápis que muda de cor, um motorzinho à combustão. Foi realmente inspirador ser orientada pelo senhor!

Aos colegas e amados alunos do Centro Educacional do Lago Norte que tanto me ensinaram e me ajudaram no meu primeiro ano de docência na educação básica, da Universidade Estadual de Goiás Câmpus Formosa onde tive a oportunidade de trabalhar com formação de professores e do Instituto Federal Goiano Câmpus Avançado Cristalina com os quais tenho aprendido diariamente...

À CAPES pelo apoio financeiro aos meus estudos.

À Deus, por ser um guia espiritual e nortear toda minha vida. 
Os contornos do meu futuro caminho começavam a delinear-se; - problema central seria a língua. Em primeiro lugar, obviamente, porque amo a língua. Amo sua beleza, sua riqueza, seu mistério e seu encanto. Só sou verdadeiramente quando falo, escrevo, leio ou quando ela sussurra dentro de mim, querendo ser articulada. Mas também porque ela é forma simbólica, morada do Ser que vela e revela, canal pelo qual me ligo aos outros, campo da imortalidade "aere perennius", matéria e instrumento de arte. É meu repertório e minha estrutura, meu jogo, modelo de todos os meus modelos, é aberta e me abre ao inarticulado. Ela é meu engajamento, nela me realizo e por ela deslizo rumo ao seu horizonte e fundamento, o silêncio do inarticulável. Ela é minha forma de religiosidade. É, quiçá, também a forma pela qual me perco. 


\section{RESUMO}

A motivação para esse projeto partiu da observação da dificuldade no processo de ensino-aprendizagem de Química tendo em vista a natureza submicroscópica dessa ciência. No contexto escolar, os estudantes são introduzidos a uma maneira diferente de entender os fenômenos a sua volta e, na maioria deles, o entendimento cotidiano é bastante diferente dos conceitos científicos que são discutidos. No caso da Química existe ainda uma outra problemática: a impossibilidade de se observar a natureza de seu objeto de estudo, sendo essencialmente entendida por meio de modelos. Assim, estudos de Johnstone (2006, 2009), Gilbert e Treagust (2009) e muitos outros realizados em vários países, apontam que uma das maneiras de se ensinar Química na educação básica é por meio da discussão dos três níveis do conhecimento químico: o macroscópico, o submicroscópico e o representacional. Segundo esses trabalhos, há uma falta de demarcação desses níveis quando os fenômenos são apresentados, gerando dificuldades no aprendizado dos conceitos. A partir dessas ideias surgiu a necessidade de repensar sobre como fazer a transição entre os três níveis do conhecimento químico de forma a facilitar a compreensão dos conceitos científicos apresentados nas aulas de Química. Para isso, foi realizada uma metodologia utilizando atividades demonstrativo-investigativas em que foram realizados experimentos (macroscópico) e a partir deles discutidas as teorias científicas que explicam os fenômenos observados (submicroscópica) e como a Química os representa utilizando modelos, concretos e simbólicos (representacional). Os conceitos científicos foram discutidos a partir das ideias de Vygotsky (2001) sendo estes apresentados utilizando sistema conceituais em que os conceitos são relacionados uns aos outros, de modo a serem organizados de acordo com os diferentes níveis de abrangência e generalidade. E para discutir como a Ciência representa os fenômenos observados utilizando a linguagem química, foram realizadas atividades envolvendo modelos e modelagem. A utilização dessa metodologia levou a resultados bastante satisfatórios pois, com o uso de sistemas conceituais, os estudantes se apropriaram de significados científicos para o tema abordado e, por meio das atividades de modelos e modelagens, conseguiram representar os fenômenos observados utilizando diferentes modos de representação. Essa pesquisa resultou em uma proposição didática que apresenta uma estratégia de ensino para os professores ensinarem o tema gases a partir da discussão dos três níveis do conhecimento químico. Esse módulo traz sugestões para quatro encontros com a descrição detalhada de como podem ser desenvolvidas as atividades. Esperase que, com a aplicação da proposição por outros docentes, estes entendam como podem ser desenvolvidas atividades em que são discutidos os três níveis, utilizando essas estratégias não só para o tema gases, mas para o estudo de outros conteúdos da Química.

Palavras-chaves: Três níveis do conhecimento químico; modelos e modelagem; estudo de gases; sistemas conceituais; experimentos demonstrativos-investigativos 


\section{AbStract}

The motivation to this project arose from the observation of the difficulty in Chemistry teaching-learning process with a view to submicroscopic nature of this Science. In the school context, students are introduced to a different way of understanding the phenomena around them and in most cases, the everyday understanding is quite different from the scientific concepts that are discussed. In case of Chemistry there is also another problem: the impossibility of observing the nature of their object of study, essentially being understood through models. Thus, studies of Johnstone (2006, 2009), Gilbert and Treagust (2009) and many others performed in several countries point out that one way of teaching chemistry in basic education is by discussing the three levels of the chemical knowledge: macroscopic, submicroscopic and representational. According to these works, there is a lack of demarcation of those levels when the phenomena are presented, creating difficulties in learning the concepts. Based on this ideas, it came the need to rethink how to transition between the three levels of the chemical knowledge in order to facilitate understanding of the scientific concepts presented in Chemistry class. For this, a methodology was performed using demonstrative-investigative activities in which experiments were carried out (macroscopic) and from them discussed scientific theories that explain the observed phenomena (submicroscopic) and how the chemistry represents using models, concrete and symbolic (representational). Scientific concepts were discussed from the Vygotsky's ideias (2001) latter being presented using conceptual system in which the concepts are related to each other so as to be arranged according to different levels of generality and coverage. And to discuss how science represents the observed phenomena using a chemical language, activities were carried out involving models and modeling. The use of this methodology led to very satisfactory results because, with the use of conceptual systems, students have appropriated scientific meanings to the topic addressed, through the activities of models and modeling, managed to represent the phenomena observed using different modes of representation. This research resulted in a didactic proposition that presents a teaching strategy for teacher to teach the subject gases from the discussion of the three levels of the chemical knowledge. This module provides suggestions for eight classes with the detailed description of how the activities can be developed. It is expected that with the implementation of the proposal by other teachers, they understand how they can develop activities in the three levels discussed, using these strategies not only for the theme gases, but for the study of other chemical contents.

Keywords: Three levels of chemical knowledge; models and modeling; gas study; conceptual systems; demonstrative-investigative experiments. 


\section{LISTA DE ILUSTRAÇÕES}

Figura 1 - Macro e Microquímica e seus níveis de representação. 16

Figura 2 - Modelo de Johnstone para os níveis de representação do conhecimento químico

Figura 3 - Aspectos do Conhecimento Químico. 20

Figura 4- Sistema Conceitual de matéria que não atende as características de Vygotsky para os conceitos científicos presente em alguns livros didáticos.

Figura 5 - Forma de Apresentação da Matéria 27

Figura 6 - Natureza da Matéria. 28

Figura 7- Ciclo GAM (Clement, 1989) 34

Figura 8 - Aprendizagem por meio de modelos proposto por Clement (2000). 35

Figura 9 - Modelo para o processo de construção de modelos. 36

Figura 10 - Relação entre as principais etapas envolvidas na modelagem. 39

Figura 11 - Etapas desenvolvidas nas atividades de modelagem.. 40

Figura 12 - Sistema conceitual e estratégias de abordagem para conceitos químicos 41

Figura 13 - Classificação das respostas para o significado de atmosfera terrestre 54

Figura 14 - Cartaz com os sistemas conceituais que foram colados na sala de aula. 56

Figura 15 - Classificação das respostas apresentadas nos questionários inicial e final para o conceito de ar.

Figura 16 - Percentual de respostas classificadas como conceito cotidiano para o conceito de ar de acordo com a ideia central do estudante.

Figura 17 - Modelo construído por um estudante representando os átomos de oxigênio, nitrogênio e hidrogênio, a partir das ideias de Dalton .

Figura 18 - Modelos construídos por diferentes estudantes representando os átomos de oxigênio, nitrogênio e hidrogênio, que não se adequaram as ideias de Dalton.

Figura 19 - Classificação das respostas apresentadas nos questionários inicial e final para a pergunta referente aos constituintes das substâncias 66

Figura 20 - Representação dos constituintes das substâncias antes, como moléculas diatômicas, e após, como átomos isolados, o aquecimento do ar. 
Figura 21 - Representação dos constituintes das substâncias antes e após o aquecimento do ar por uma estudante no qual as moléculas são representadas como aglomerados de átomos.

Figura 22 - Representação dos constituintes das substâncias antes e após o aquecimento do ar por uma estudante em que as entidades são representadas com formas geométricas diferentes.

Figura 23 - Modelos de dois estudantes em que há um aumento dos espaços vazios entre as entidades.

Figura 24-Modelo de uma estudante em que se observa uma diminuição dos espaços vazios entre as entidades em decorrência do aumento no tamanho das partículas

Figura 25 - Modelo de uma estudante em que se observa o aumento no número de moléculas após 0 aquecimento.

Figura 26 - Modelo de uma estudante em que se observa a concentração de moléculas em determinados espaços do recipiente.

Figura 27 - Exemplos de representações dos constituintes das substâncias, moléculas diatômicas presentes no ar antes, durante e após a compressão na seringa 81

Figura 28 - Modelos de massinha de modelar que representam os constituintes das substâncias envolvidas na eletrólise da água, sendo elas: água, gás oxigênio e gás hidrogênio

Figura 29 - Classificação das expressões representacionais para eletrólise da água representadas pelos estudantes.

Figura 30- Exemplo de expressão representacional transcrita a partir do modelo concreto da eletrólise da água escrita um estudante e classificada como totalmente correta. 88

Figura 31 - Expressões representacionais classificadas como parcialmente corretas 89

Figura 32 - Exemplos de expressões representacionais da eletrólise da água escritas pelos estudantes e classificadas como parcialmente corretas. 


\section{SUMÁRIO}

INTRODUÇÃO

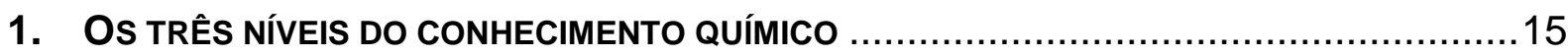

2. Conceitos Cotidianos e Conceitos Científicos .....................................22

3. A UTILIZAÇÃo dE MOdELOS E MOdELAGEM NO ENSINO DE QUíMICA ........................30

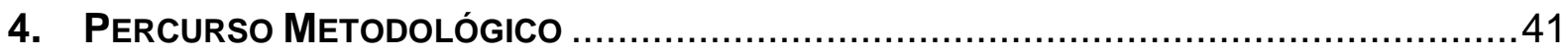

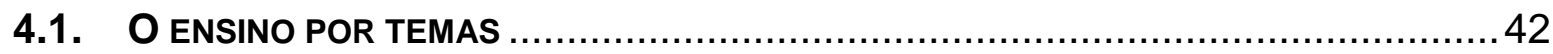

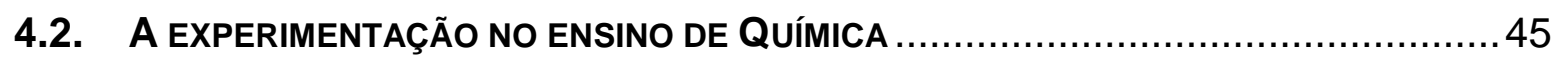

4.3. DESCRIÇÃo DAS ESTRATÉGIAS METOdOLÓGICAS ................................... 47

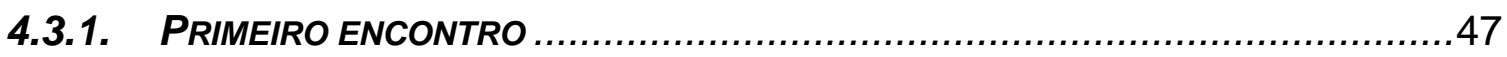

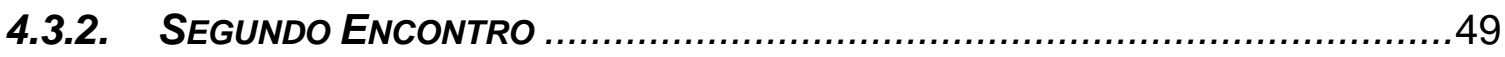

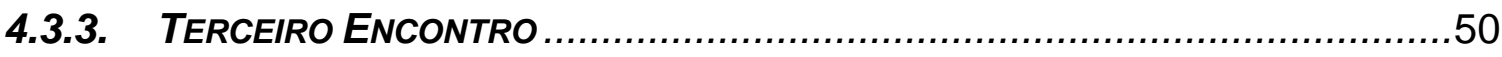

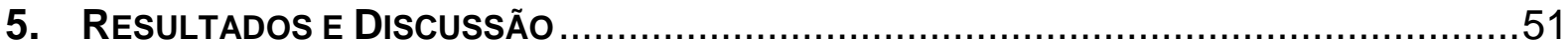

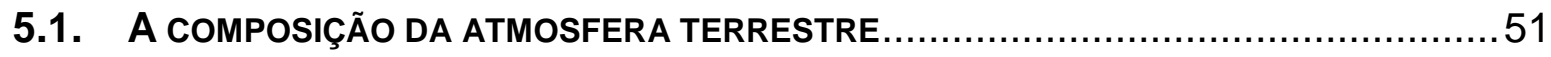

5.2. O CONCEITO DE AR ATMOSFÉRICO ...................................................... 55

5.3. AS SUBSTÂNCIAS E SEUS CONSTITUINTES .............................................. 60

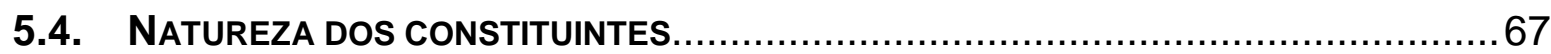

5.5. ELABORANDO A EXPRESSÃo REPRESENTACIONAL DE UMA REAÇÃo QUÍMICA .......83

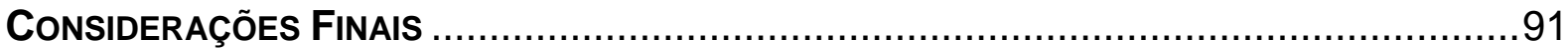

REFERÊNCIAS BIBLIOGRÁFICAS .................................................................... 94

Apêndice A - Proposta de Ação Profissional 


\section{INTRODUÇÃO}

Há na atualidade um amplo debate sobre a qualidade do Ensino de Ciências. Inúmeros autores apontam que nossa educação básica não é satisfatória, e esses dados são corroborados por avaliações como o PISA (Programa Internacional de Avaliação de Alunos), 2012, que apesar de bastante criticado, indicou que os estudantes brasileiros pouco sabem relacionar os conhecimentos científicos que aprendem na escola com as situações cotidianas. Dentre as três áreas avaliadas, Leitura, Matemática e Ciências, a nossa foi a que apresentou o pior desempenho.

Além disso, é notável um crescente desinteresse dos estudantes pela Química. Possivelmente isso ocorra pela disciplina ser considerada abstrata, e de difícil compreensão, além de requerer o domínio de sua representação para entendê-la. Chassot (2013) relata que essa rejeição é fruto de um ensino inútil e não prazeroso, desconexo do cotidiano, não contribuindo para que os alunos sejam capazes de aplicar tais conhecimentos em seu dia-a-dia.

Isso se reflete em outro dado preocupante: a baixa procura dos jovens por cursos de licenciatura de Química. Ao observarmos a relação candidato por vaga de vestibulares da Universidade de Brasília (UnB), percebe-se que a quinze anos atrás, em 2000, a demanda pelo curso de licenciatura em Química era de 10,19 candidatos por vaga, enquanto em 2014 foi de apenas 2,63․ Esses dados se repetem em inúmeras universidades em todo país, mesmo em regiões nas quais há uma grande carência de professores de Química.

Quais seriam os problemas que levam os estudantes a não se interessarem por essa área? Alguns dos inúmeros motivos apresentados na literatura que podem explicar essa grande insatisfação com a disciplina Química são resultantes da forma como ela é ensinada na educação básica, como indicado a seguir:

- o ensino é desvinculado da realidade dos estudantes (MORTIMER, MACHADO, ROMANELLI, 2000), que acabam memorizando conceitos, sem compreendê-los. Desta forma, eles não conseguem perceber como os

\footnotetext{
${ }^{1}$ Esses dados foram obtidos observando as tabelas de demanda de candidatos relativos aos vestibulares dos segundos semestres, disponíveis no site do CESPE (www.cespe.unb.br).
} 
conhecimentos químicos podem explicar diversos fenômenos que ocorrem no dia-a-dia;

- $\quad$ os conceitos são apresentados de forma estanque, como verdades absolutas (GOMES, 2012). A forma como a Ciência é ensinada, faz com que essa seja vista como imutável, e não como uma construção humana. Segundo Chassot (2013), a Ciência deveria ser vista não como a verdade, mas aceitando verdades transitórias, porém não é dessa maneira que essa disciplina é discutida no contexto escolar. Essa falta de entendimento sobre a natureza da Ciência faz com que os estudantes se afastem, pois, qual seria a necessidade de se estudar o que está acabado?

- Os currículos são inadequados e extensos, apresentando um número excessivo de conteúdos e sendo organizados não relacionando os conceitos apresentados de forma a favorecer o processo ensino-aprendizagem. Isso faz com que ocorra uma aprendizagem de conteúdos fragmentados pelos estudantes (ARAÚJO, SILVA, TUNES, 1995). Para Schnetzler (2010), os professores de Química deveriam "ensinar bem poucos conteúdos, mas que sejam fundamentais para expressar a identidade e a importância da Química" (p.152).

Estes são apenas alguns dos muitos problemas vivenciados pelos estudantes da educação básica da maioria das escolas desse país, que devem se adequar aos moldes tradicionais de ensino e, quando isso não ocorre, frequentemente são vistos como os culpados por serem desinteressados ou não terem a base teórica necessária.

Considerando que a prática docente é também reflexo de sua formação, percebe-se que muitos cursos de licenciatura não têm favorecido a formação de professores que desenvolvam abordagens alternativas para melhorar o ensino de Química. Nos cursos de formação docente verifica-se: a falta de integração entre as disciplinas específicas e pedagógicas; o distanciamento entre situações reais e a prática; a existência de visões simplistas do ato de ensinar por parte de alguns docentes, que acreditam que para se ensinar é necessário ter um vasto conhecimento da área e saber algumas técnicas pedagógicas; ênfase na crítica ao modelo tradicional sem trazer novas estratégias e alternativas para superá-lo (SCHNETZLER, 2010). 
Tendo consciência desses vários problemas e contando com o aporte teóricoprático resultante de uma excelente formação docente, durante meu primeiro ano de docência, buscando tornar o ensino de Química mais agradável e também mais lógico, passei a utilizar em minha prática pedagógica abordagens diferenciadas, utilizando experimentos demonstrativos-investigativos para apresentar e discutir com os estudantes os conteúdos químicos. Trabalhei procurando explicitar os três níveis do conhecimento químico: macroscópico, submicroscópico e representacional, estratégia que conheci no período em que fui bolsista no Laboratório de Pesquisa e Ensino de Química (LPEQ-UnB). A escolha do termo submicroscópico em substituição ao termo microscópico com o qual estava mais habituada, ocorreu devido a possibilidade de os estudantes entenderem erroneamente que é possível observar diretamente átomos, moléculas, ligações químicas, utilizando um microscópico óptico, conforme relatam Gilbert e Treagust (2009).

Nessa perspectiva, eu escolhia experimentos em que fosse possível observar fenômenos que seriam explicados por meio de conceitos discutidos com os estudantes ou que eu gostaria de introduzir na aula. Assim, inicialmente é trabalhado o nível macroscópico, que seria a observação de algum fenômeno, por exemplo, a liberação de um gás, a formação de um novo material, dentre outros; depois é discutido o nível submicroscópico, que é como a Ciência explica o que observamos; e no último nível, o representacional, é feita a representação utilizando a linguagem química - fórmulas, equações químicas, símbolos.

Porém, em uma das atividades propostas, solicitei que os alunos representassem por meio do desenho de esferas as substâncias e as reações químicas apresentadas, e surgiram diversas dúvidas. A partir das respostas obtidas e dos diálogos realizados após a resolução das questões, percebi que eles tinham dificuldade em fazer a transição entre os modelos de natureza atômico-molecular e as expressões representacionais para esses modelos.

Face a esse problema surgiu a seguinte questão: "Como auxiliar os estudantes na transição entre os níveis macroscópico, submicroscópico e as expressões representacionais, de modo a facilitar a compreensão dos conceitos científicos?". Baseado nas dificuldades observadas, o objeto de pesquisa desse trabalho consistiu em buscar estratégias para auxiliá-los na transição entre os níveis macroscópico, submicroscópico e representacional, com intuito de que isso viabilize o aprendizado de Química. 
Para equacionar esse problema pensamos nas seguintes hipóteses:

> A transição entre os níveis macroscópico, submicro e representacional pode ser facilitada pelo uso de sistemas conceituais hierarquicamente organizados.

Levando em consideração esses sistemas e a forma tradicional de abordagem do estudo da Química, nota-se que o professor não explicita de forma clara os diferentes níveis, não situando os conceitos em um sistema hierarquizado de interrelações. Deste modo, a compreensão de atributos concretos antes da introdução dos conceitos científicos de acordo com a hierarquia deve facilitar no entendimento dos diferentes níveis por parte dos estudantes (SCHNETZLER, 1988).

A transição entre o nível submicroscópico e representacional pode ser facilitada pela utilização de modelos e modelagens.

A discussão do nível submicroscópico que tem uma natureza atômicomolecular gera dificuldades na compreensão dos conceitos apresentados por parte dos alunos, por ser muito abstrata. Assim, a utilização de modelos no ensino pode possibilitar que os estudantes percebam como estes são construídos, quais suas funções e limitações.

Desta forma, o presente trabalho teve como objetivo investigar se o uso de sistemas conceituais hierarquicamente organizados e uma estratégia utilizando modelos pode favorecer o desenvolvimento de conceitos científicos, e a partir desses resultados desenvolver uma proposta metodológica que possibilite a transição entre os três níveis - Macroscópico, Submicroscópico e Representacional - utilizando experiências demonstrativas-investigativas relacionadas ao tema atmosfera. 


\section{OS TRÊS NÍVEIS DO CONHECIMENTO QUíMICO}

As dificuldades vivenciadas por professores e alunos no estudo dos conceitos químicos foram discutidas por Johnstone (2009). Seu trabalho relata que apesar dos avanços na pesquisa em Ensino de Química, muitos problemas identificados na década de 70 ainda então presentes nos dias atuais.

Em 1982, ele foi um dos primeiros autores a propor um modelo buscando explicar os níveis de representação do conhecimento químico em seu artigo "Macro and micro-chemistry", no qual explica que essa Ciência pode ser visualizada em pelo menos três níveis, que seriam: (1) descritivo e funcional, (2) atômico e molecular, e (3) representacional.

O primeiro deles se refere a parte observável da Química, podendo ser descrita e mensurada a partir de propriedades como: densidade, inflamabilidade, cor, odor, dentre outras. Já o segundo, se refere a como são explicados os fenômenos observados no macroscópico, sendo utilizados diversos conceitos, como os de átomos, íons, moléculas, polímeros e ligações químicas, para fornecer uma imagem mental, um modelo, de modo a se pensar e racionalizar o nível descritivo. E o último nível é a forma com a qual os químicos buscam representar as substâncias e transformações por meio de símbolos e equações, utilizando a linguagem científica (JOHNSTONE, 1982).

Johnstone (1982) explica que os químicos saltam entre esses três níveis livremente, fazendo uma espécie de ginástica mental, tendo facilidade nessa transição. Porém, na sala de aula, os estudantes ao observarem transformações químicas pela primeira vez, operam apenas o nível descritivo/funcional, enquanto o professor em suas explicações utiliza os três níveis. Isso faz com que a maioria dos alunos não consiga acompanhar o seu raciocínio e não compreenda os conceitos apresentados.

Assim, Johnstone (1982) separa esses níveis de representação em dois grupos: a macro e a microquímica (Figura 1). Segundo o autor, para a educação básica que tem como foco a formação para cidadania, a microquímica não seria o aspecto mais importante, e sim a macroquímica pois os alunos ainda operam preferencialmente no âmbito do visível. A microquímica deveria ser utilizada para 
discussão dos fenômenos observados (macroquímica), e para isso ele sugere que sejam realizados experimentos que tenham efeito visual e possibilitem que esses fenômenos sejam explicados.

Figura 1 - Macro e Microquímica e seus níveis de representação

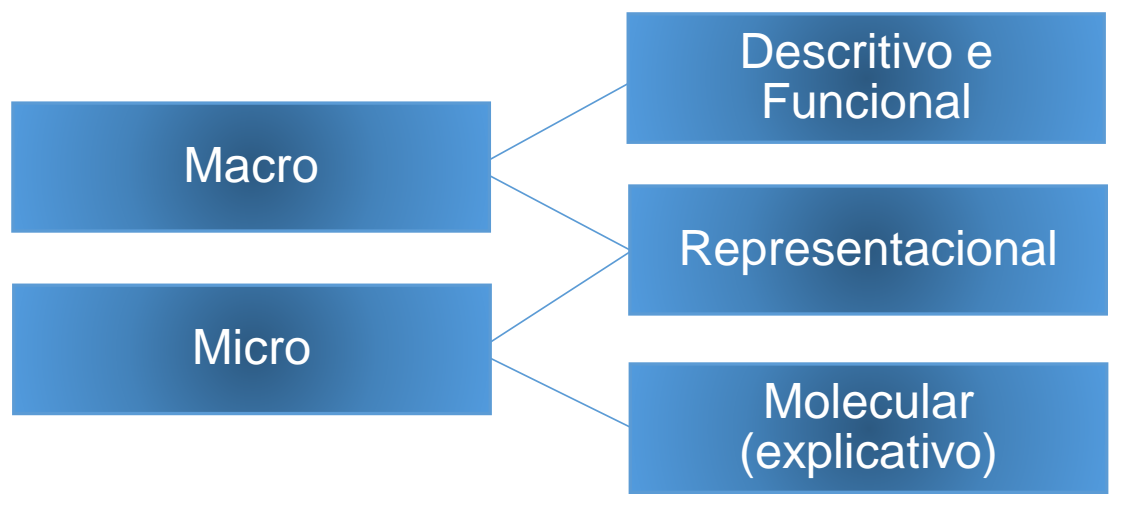

Fonte: Johnstone (1982, p.378)

Após perceber incoerências em seu modelo, Johnstone (2009) fez uma reorganização dos três níveis por ele definidos em um triângulo. Além disso, foram feitas algumas modificações em seu modelo, renomeando os três níveis em: (1) macro e tangível, (2) molecular e invisível, (3) simbólico e matemático. Esses seriam os três componentes que representam a Química e não haveria uma hierarquia entre eles (Figura 2).

Figura 2 - Modelo de Johnstone para os níveis de representação do conhecimento químico

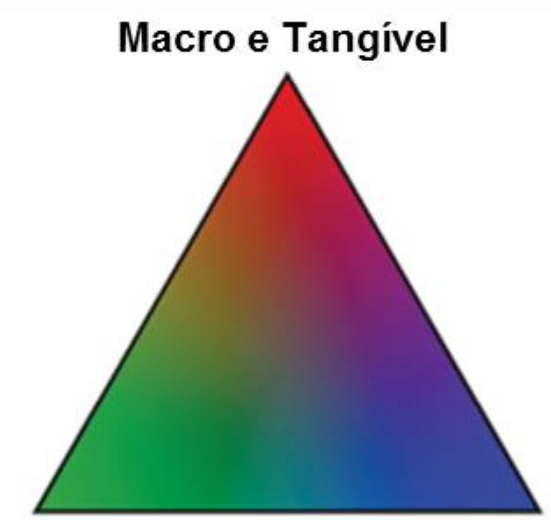

Molecular e Invisivel

Simbólico e Matemático

Fonte: Adaptado de Johnstone (2009, p. 24) 
Johnstone (2009) explica que a abordagem do professor pode se situar em diferentes localizações desse triângulo. Cada um dos vértices representa uma abordagem totalmente voltada para um dos três níveis. Por exemplo, quando o professor somente mostra a efervescência de um comprimido, o conhecimento é totalmente macro e tangível. A partir do momento em que passar a explicar o fenômeno utilizando os modelos científicos, a abordagem se encontrará em algum ponto da aresta entre o macro e tangível e o molecular e invisível. Dependendo da ênfase que é dada para cada um dos níveis, ele estará mais próximo (ou mais distante) de um desses dois vértices.

Como foi dito anteriormente, em suas explicações o professor transita livremente sobre o triângulo, discutindo simultaneamente os três aspectos do conhecimento químico, estando essa abordagem situada dentro do triângulo. Johnstone $(2006,2009)$ acredita que quando isso ocorre, há uma potencial sobrecarga na memória de trabalho² (Working Memory Space) dos estudantes, levando a uma dificuldade na compreensão dos conhecimentos químicos por parte deles. Para evitar essa sobrecarga, é importante que os alunos tenham em sua memória de longo prazo ${ }^{3}$ as fixações, os conhecimentos prévios necessários, para fazer a ligação com os novos conhecimentos que se deseja ensinar. Por exemplo, quando o professor inicia sua aula do tema sais falando sobre o sulfato de cobre, provavelmente os estudantes não possuem em sua memória de longo prazo informações adequadas que possam ancorar esse novo conhecimento. Sugere-se que ele inicie sua aula utilizando aspectos que estão mais presentes no cotidiano do aluno, falando sobre o sal de cozinha e, a partir dele, novos conceitos sejam discutidos.

Deste modo, para que ocorra uma melhor compreensão da Química é importante que o aluno transite entre os vértices desse triângulo, lidando com os três componentes do conhecimento químico. E, para Johnstone (2006), uma alternativa

\footnotetext{
2 Johnstone (2009) acredita que o pensamento consciente tem um espaço limitado. Esse espaço de trabalho é utilizado para duas funções: armazenar informações temporárias e processá-las. Quando há um recebimento de muitas informações, resta pouco espaço para processá-las. O mesmo vale para quando é necessário muito processamento, não sendo possível assimilar muitas informações. Quando isso ocorre, há uma sobrecarga na memória de trabalho e o aprendizado fica comprometido.

${ }^{3} \mathrm{~A}$ memória de longo prazo é a área da memória que recebe as informações da memória de trabalho, possuindo a capacidade de armazená-las por tempo indeterminado em um espaço ilimitado. Johnstone (2009) explica que quando os estudantes possuem na memória de longo prazo as fixações da informação que está sendo recebida torna-se mais fácil dela também ser armazenada nessa área, e quando não há essas fixações o estudante acaba memorizando os conceitos.
} 
seria trabalhar um vértice do triângulo por vez, seguido pelo uso do lado (aresta) e caminhar para os outros vértices, para depois levar o aluno ao centro do triângulo. Por exemplo, ao invés do professor iniciar a aula escrevendo no quadro "ligações de hidrogênio" nos moldes tradicionais de ensino, ele entra e indaga aos estudantes o porquê de alguns insetos poderem caminhar sobre a água, fenômeno que provavelmente eles já observaram em seu cotidiano (macro e tangível), em seguida o professor faz uma demonstração pegando um copo d'água e colocando um clipe de papel para flutuar na superfície dela (continuando no vértice do triângulo macro e tangível), e após discutirem o observado, ele vai explicando o fenômeno em questão introduzindo o conceito de tensão superficial (caminhando pelo lado do triângulo entre o macro e tangível e o molecular e invisível), e a partir desse conceito ir falando sobre as interações entre as moléculas de água que explicam a formação dessa tensão e, só depois, falar sobre ligação de hidrogênio (molecular e invisível). Após essa explicação, ele faz a representação da molécula de água e das interações entre as moléculas que explicam a tensão superficial da água (simbólico e matemático).

Para que isso ocorra, faz-se necessária uma reorganização dos conteúdos que são discutidos nas aulas para que haja a utilização de uma abordagem a partir do que é familiar, dos interesses dos alunos, pois nesses casos os estudantes já têm conhecimentos armazenados na memória de longo prazo, e a partir deles pode-se introduzir o novo. Para isso, alguns assuntos deveriam ser excluídos dos currículos, outros adiantados ou adiados. Os conceitos deveriam ser discutidos a partir do macroscópico (macro e tangível) e gradualmente serem enriquecidos com aspectos submicroscópicos (molecular e invisível) e representacionais (simbólico e matemático) (JOHNSTONE, 2009).

Mortimer, Machado e Romanelli (2000) também defendem um currículo no qual haja um diálogo entre o discurso científico e o cotidiano. Para os autores, o ensino de Química tradicional pouco se preocupa com as questões do dia-a-dia, tratando essa Ciência somente do ponto de vista formal. Para torná-la mais interessante, é importante que o discurso científico faça sentido para o estudante e isso é possível ao dialogar a partir de ideias informais, de contextos de natureza social e tecnológica, que tornem esses conceitos mais significativos.

Eles explicam que nos currículos tradicionais há uma ênfase exagerada nos aspectos conceituais da Química em detrimento das possíveis aplicações dos conceitos no cotidiano, como por exemplo no estudo de química orgânica, no qual os 
estudantes memorizam etapas para nomear representações de moléculas orgânicas, decoram estruturas dessas moléculas e só depois é falado sobre exemplos de substâncias orgânicas e suas propriedades. Nesses casos, os conceitos apresentados só são aplicados depois de serem discutidas uma cadeia de prérequisitos. Para eles, "o pressuposto de que se deva, no ensino, esgotar um conceito para poder aplicá-lo pode ser questionado, pois é justamente nas aplicações do conceito que se explicitarão as relações a serem estabelecidas entre os conceitos" (MORTIMER, MACHADO, ROMANELLI, 2000, p. 275). No exemplo anterior, isso significa que a partir de materiais que tenham em sua constituição substâncias classificadas como orgânicas e do conhecimento de algumas de suas propriedades, o professor poderia discutir como a Ciência explica essas propriedades e fenômenos nas quais essas substâncias estão envolvidas, inter-relacionando os conceitos discutidos.

Sobre os conceitos ensinados em Química, Mortimer, Machado e Romanelli (2000), baseado em Johnstone (1982), também distinguem três aspectos desse conhecimento: (1) fenomenológico, (2) teórico e (3) representacional. fenomenológico se refere aos aspectos visíveis e concretos, como a efervescência de um comprimido, a combustão de uma vela, além de outros que podem ser percebidos indiretamente, como por exemplo a produção de pães e bolos em uma confeitaria. Nesse aspecto também podemos incluir a observação de reações químicas por meio de imagens técnicas ${ }^{4}$, obtidas com equipamentos eletrônicos, e que tem substituído diversas experiências empíricas (TERCl et al., 2012). É o caso da espectroscopia, que permite a identificação indireta das substâncias formadas em uma reação a partir de imagens geradas por um equipamento, sem a necessidade de isolá-las, por exemplo. O aspecto teórico abrange as explicações de natureza atômico-molecular, essencialmente abstratas e baseadas em modelos. Se refere a como a Ciência explica determinado fenômeno, utilizando conceitos de átomos, moléculas, íons, dentre outros. O nível representacional abarca as representações por meio da linguagem científica, utilizando-se de equações, fórmulas, gráficos e símbolos.

\footnotetext{
${ }^{4}$ Flusser (1985) apud Terci (2012) relata que atualmente estamos vivendo a terceira revolução ferramental, chamada de revolução telemática, sendo resultado do advento de equipamentos eletrônicos. Com estes equipamentos obtemos imagens que são, na verdade, produtos de teorias e textos científicos, bastante observadas na Ciência e, consequentemente, na sociedade.
} 
Baseando-se nos estudos de Johstone (1982), Mortimer, Machado e Romanelli (2000) também organizaram os aspectos do conhecimento químico em um triângulo, destacando suas inter-relações (Figura 3).

Figura 3 - Aspectos do Conhecimento Químico

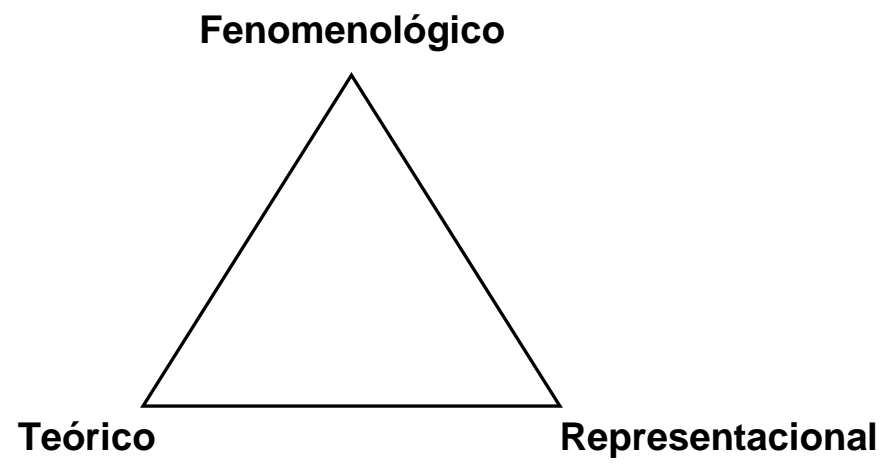

Fonte: Mortimer (2000, p. 277) $)^{5}$

Segundo Mortimer, Machado e Romanelli (2000), um dos problemas do ensino de Química é a ênfase no aspecto representacional em detrimento dos outros, não sendo dado destaque aos fenômenos presentes no ambiente e fazendo com que os estudantes acreditem que os símbolos e fórmulas apresentados nas aulas são "reais", e não modelos de representação da matéria. É necessário trabalhar os três aspectos do conhecimento químico, relacionando teoria e experimento e, consequentemente, pensamento e realidade.

Gilbert e Treagust (2009) explicam que uma das dificuldades para a utilização dos três níveis de representação do conhecimento químico é a ampla variedade de nomes dados a cada um deles. No trabalho deles são apresentadas pelo menos 10 nomenclaturas diferentes para os níveis de representação, dentre eles: para o primeiro nível - nível macroscópico, mundo macroscópico, nível macro; para o segundo - nível microscópico, nível submicroscópico, nível submicro; e para o terceiro - nível simbólico e representacional; quadro que mostra uma falta de consenso entre os pesquisadores de qual terminologia seria a mais adequada. Para evitar possíveis ambiguidades, esses autores optaram por não utilizar o termo micro ou microscópico por possibilitarem que os estudantes entendam ser possível visualizar através de equipamentos (microscópico óptico) e também por uma terminologia mais breve, a dizer: macro, submicro e simbólico.

${ }^{5}$ Retirado de Minas Gerais, SEEMG, 1998, citado por Mortimer, Machado e Romanelli (2000) 
Sendo assim, acreditamos que um dos problemas do ensino de Química é a dificuldade que os professores sentem em auxiliar os estudantes a transitarem entre os níveis apresentados por Johnstone (1982, 2006, 2009), Mortimer, Machado e Romanelli (2000), Gilbert e Treagust (2009) e tantos outros. Estes, apesar das diferentes denominações, são bastante semelhantes em sua essência. Em nosso trabalho, chamaremos os três níveis do conhecimento químico utilizando termos que estamos mais habituados agregando a ideia de Gilbert e Treagust (2009) para a utilização do prefixo -sub em conjunto com o termo microscópico, sendo chamados neste trabalho de aspectos macroscópicos, submicroscópicos e expressões representacionais.

Cabe ressaltar que não basta que futuros professores aprendam na formação inicial cada um desses três níveis e a importância de se transitar neles em disciplinas da área pedagógica, pois esses

(...) conhecimentos pedagógicos dissociados dos conteúdos químicos que os futuros professores terão que ministrar tem pouca ou reduzida contribuição para sua formação docente, uma vez que os professores tendem a não utilizar os métodos de ensino que lhes foram ensinados no decorrer de sua formação (SCHNETZLER, 2010, p. 158).

É importante que eles tenham acesso ao como fazer, conhecendo estratégias nas quais essas ideias são implementadas e possam adaptá-las ao contexto escolar que futuramente serão inseridos. Além de refletir sobre os problemas no ensinoaprendizagem de Química, devem ser mostradas alternativas didáticas, estratégias adotadas por docentes que se diferem do modo tradicional e que apresentam resultados positivos na educação básica.

Percebendo a importância dos três níveis do conhecimento químico, cabe refletir como o professor deve auxiliar na transição de um nível para o outro. O nível macroscópico ao ser observado pelos estudantes, possibilita diferentes interpretações que estão permeadas de impressões e significados, trazidos de suas vivências. Já no submicroscópico, que se resume a como a Química explica os fenômenos, utilizam conceitos mais abstratos e distantes da realidade, cabendo ao professor por meio do diálogo possibilitar que esses significados se ampliem. Assim, é necessário compreender como esses conceitos são formados e qual o papel do professor e da educação formal neste processo, o que passaremos a abordar no próximo capítulo. 


\section{Conceitos Cotidianos e Conceitos Científicos}

No intuito de entender as formulações teóricas de Vygotsky sobre os conceitos cotidianos e científicos, é importante entendermos como ele descreve a relação entre o pensamento e a linguagem.

Tunes (1995) explica que, para Vygotsky, até certo momento da vida do indivíduo, o pensamento e a fala teriam linhas de desenvolvimento diferentes, havendo um estágio pré-verbal no desenvolvimento do pensamento, e um préintelectual no da fala. Por exemplo, antes de conseguir se comunicar de forma verbal, a criança emite sons como o choro e o balbucio, basicamente para comunicar estados afetivos e emocionais. Nessa fase, que seria a pré-intelectual da fala, o desenvolvimento da linguagem não guardaria relação com o pensamento.

É no momento em que a criança aprende o nome das coisas, por volta dos dois anos de idade, que se inicia a relação pensamento-linguagem. Nesse instante, os estágios pré-verbal e pré-intelectual se cruzam e o pensamento passa a ser verbalizado, por meio da fala. Da intersecção entre o pensamento e a fala surge o pensamento verbal (TUNES, 1995).

O pensamento verbal é como Vygotsky (2001) chama o modo de pensar tipicamente humano, pois nós, diferentemente de outros animais, somos capazes de estabelecer relações entre fatos e acontecimentos por intermédio da palavra, sem a necessidade de sermos atingidos imediatamente pelos sentidos.

A partir desses estudos percebemos a importância da palavra (VYGOTSKY, 2001). Quando falamos a palavra "mesa", podemos pensar e explicitar atributos que distinguem diferentes mesas, como: um tampo quadrado com as "pernas" nos vértices, ou redondo, com as "pernas" mais ao centro, ou outros inúmeros tipos de mesas. A própria palavra "perna" adquire um outro significado nesse contexto, deixando de ser lida como uma parte do corpo humano. Assim, com base em atributos comuns, como uma superfície plana no qual podem ser colocados objetos, podemos chamar duas "mesas" pela mesma palavra.

Para Vygotsky (2001), é no significado da palavra que se encontra a mais simples unidade do pensamento e linguagem, a unidade do pensamento verbal. Ele teve como ponto fundamental a percepção de que ao longo da vida esses significados se desenvolvem. Assim: 
Generalização e significado da palavra são sinônimos. Toda generalização, toda formação de conceitos é o ato mais específico, mais autêntico e mais indiscutível de pensamento. (VYGOTSKY, 2001 p. 398)

Portanto, é no significado da palavra, no conceito, que é possível encontrar pensamento e linguagem: "O conceito ou o significado é, por assim dizer, uma relação (representação abstraída) encarnada na palavra" (TUNES, 1995, p. 31). Como existem diferentes relações entre pensamento e fala, existem também diferentes tipos e significados para o pensamento verbal. Deste modo, é importante entendermos as diferentes classes do pensamento verbal reconhecidas por Vygotsky (2001).

Para Vygotsky (2001), existem pelo menos duas classes do pensamento verbal: os conceitos cotidianos, que se referem a significados desenvolvidos na interação social, e conceitos científicos; que são constituídos no ensino formal, normalmente na escola (TUNES, 1995).

Como os conceitos cotidianos e científicos se originam em condições diversas, o próprio curso do desenvolvimento desses conceitos se torna diferente. Os conceitos cotidianos se desenvolvem desde o momento em que a criança começa a falar. Com o auxílio de seus pais, ela aprende diferentes palavras a partir de observações do mundo real. Com o tempo, passa a utilizar a mesma palavra para se referir a objetos que tenham características semelhantes ao que ela aprendeu, desenvolvendo processos de generalização. Nessa aquisição de conceitos, a criança aplica a palavra a uma classe de objetos sem saber qual o critério que lhe permite incluí-la naquele grupo.

Podemos citar um exemplo em uma aula de Ciências no qual o professor deseja trabalhar o conceito de metal com seus estudantes. Ao perguntar o que é um metal para os alunos, eles podem responder: ferro, alumínio, prata, dentre outros. Percebese que a palavra metal é uma categoria que se refere a um grupo de objetos, é uma categoria abstraída. Nesse conceito apresentado pelos estudantes a palavra se relaciona diretamente ao objeto. Vygotsky (2001) chama esse tipo de significado de conceito cotidiano.

À medida que ocorre o desenvolvimento cognitivo da criança, as generalizações primitivas vão sendo substituídas por generalizações do tipo 
superiores, que mais tarde darão origem aos conceitos científicos ${ }^{6}$. Esse processo exige que a criança tenha desenvolvido habilidades como: abstração, atenção deliberada, saiba comparar e diferenciar, e outras, e por isso, esse desenvolvimento não ocorre prontamente (TOLENTINO et al., 1986).

A escola é o principal espaço de desenvolvimento de processos psicológicos complexos. Nesse espaço os alunos aprendem os conceitos científicos. Estes, diferentemente dos conceitos cotidianos, têm um conceito mediado por outro conceito, e têm como principal característica serem organizados em um sistema hierárquico de inter-relações (TUNES et al., 2002).

Para Tunes et al. (2002), o aprendizado desses conceitos exige que os estudantes desenvolvam uma consciência reflexiva, se apropriando de regras lógicas que permitam ligar um significado a outro, refletindo sobre seu próprio ato de pensar. Nessa perspectiva, Tolentino et al. (1986) explicam:

É nesse sentido, portanto, que o ensino de conceitos científicos liga-
se ao desenvolvimento de processos psicológicos complexos: quando
se opera com eles, há necessidade de se centrar a atenção no próprio
ato de pensamento. Diferentemente, os conceitos cotidianos exigem
apenas que se focalize o objeto ao qual se refere. (TOLENTINO,
SILVA, ROCHA-FILHO, TUNES, 1986, p. 1722)

Cabe ressaltar que, para Vygotsky (2001), os conceitos apropriados na escola não substituem os conceitos cotidianos, existindo diferentes formas do pensamento verbal em um mesmo indivíduo. Estes conceitos não são isolados, mas guardam interrelações, influenciam e sofrem influências dos outros em seu processo de desenvolvimento. O papel do professor nesse contexto é o de auxiliar os estudantes no desenvolvimento de conceitos científicos, que são diferentes dos conceitos que eles aprendem no cotidiano. A escola não busca substituí-los, mas sim possibilitar que eles aprendam uma nova forma de pensar.

Desse modo, a partir dos estudos de Vygotsky (2001) percebe-se a importância de, ao se ensinar os conceitos químicos, perceber as inter-relações e hierarquias entre eles. Para Tolentino et al. (1986):

\footnotetext{
${ }^{6}$ Tunes (1995) relata que os conceitos científicos seriam um tipo específico de conceito verdadeiro ou não-espontâneo apresentados por Vygotsky. Em seus trabalhos não foram identificados outros tipos de conceitos verdadeiros, apenas os conceitos científicos.
} 
(...) um sistema de conceitos científicos deve se caracterizar por apresentar uma hierarquização de conceitos, segundo sua abrangência, orientando-se dos mais abrangentes para conceitos subjacentes, menos abrangentes, com relações de subordinação bem definidas. (TOLENTINO, SILVA, ROCHA-FILHO, TUNES, 1986, p. 1722)

Portanto, os conceitos científicos são participantes de um sistema hierarquicamente organizado de acordo com o nível de abrangência e os conceitos de mesmo nível devem ser mutuamente excludentes entre si. Quando são apresentados conceitos que não seguem essas características, eles geram incoerências e confusões conceituais.

Assim, Tolentino et al. (1986) analisaram sistemas conceituais que apareciam nos livros didáticos, observando se estes atendiam as ideias de Vygotsky que caracterizam um conceito científico. Percebendo diversos problemas conceituais, como a falta de uma hierarquia e a presença de conceitos de mesmo nível não excludentes entre si, concluíram que "(...) as relações de subordinação entre os diversos níveis de abrangência dos conceitos não atendem aos requisitos lógicos mencionados" (TOLENTINO et al., 1986, p. 1723). Esses autores ao observarem como eram definidos alguns conceitos químicos nos livros didáticos analisados consideraram que os conceitos são ali apresentados como conceitos cotidianos, se preocupando apenas com o objeto, e não focando no próprio ato de pensar. Um exemplo de sistema conceitual que não se adequa as ideias desses autores é apresentado na Figura 4.

Nesse sistema conceitual (Fig. 4) presume-se que as substâncias simples e compostas ocorram apenas em um tipo de matéria homogênea, nas substâncias puras $^{7}$. Além disso, pode-se concluir que as substâncias puras sempre são matéria homogênea, ou seja, a classificação da água destilada no estado sólido e líquido contida em um recipiente, segundo esse sistema, deveria ser matéria homogênea, o que seria um conceito equivocado.

\footnotetext{
${ }^{7}$ Entendemos que a utilização do termo "substância pura" é um pleonasmo, pois conforme será apresentado nos sistemas conceituais Formas de Apresentação da Matéria (Figura 5) e Natureza da Matéria (Figura 6), as substâncias são formadas por apenas um tipo de constituinte, sendo necessariamente puras. Sugerimos a utilização do conceito de "substância" sem o adjetivo "pura".
} 
Figura 4 - Sistema Conceitual de matéria que não atende as características de Vygotsky para os conceitos científicos presente em alguns livros didáticos

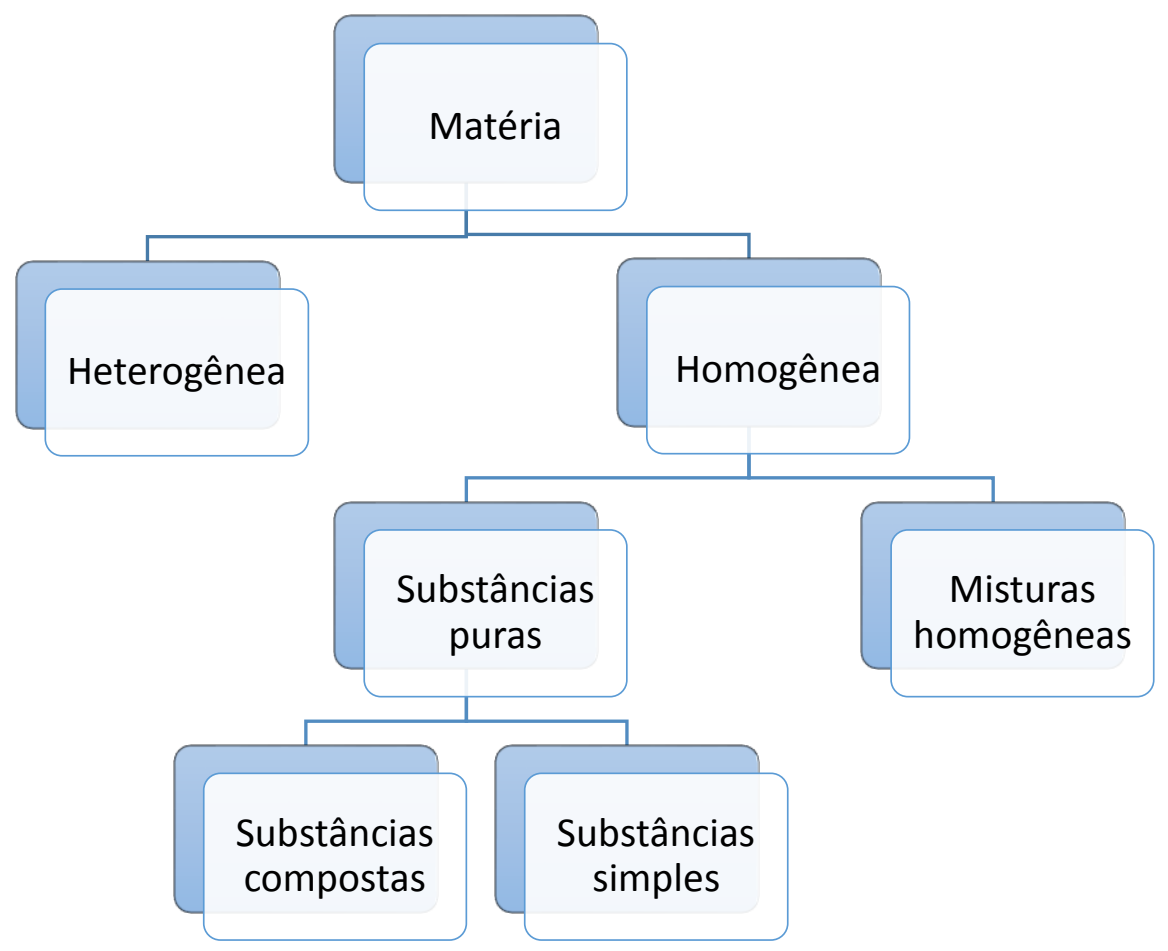

Fonte: Tolentino et al. (1986)

Deste modo, Tolentino et al. (1986), Silva et al. (1986), Tunes et al. (1989) e Rocha-Filho et al. (1988), propuseram novos sistemas, considerando a (1) natureza da matéria, (2) suas formas de apresentação, (3) quanto à natureza de seus constituintes, e um (4) quanto à natureza dos átomos dos seus constituintes, considerando a lógica do pensamento científico proposta por Vygotsky.

No primeiro trabalho, eles apresentam um sistema conceitual para natureza da matéria. Essa escolha se deu pelo fato de este conduzir a conceituação da área e sendo possível conhecer o objeto de estudo da Química. Eles explicam que matéria se encontra em um sistema mais abrangente, que é o de universo. No mesmo nível hierárquico, está o conceito de energia, que não deve ser aprofundado na Química pois é objeto de estudo da física. Para cada um dos conceitos que participam do sistema, foi proposto um enunciado:

- Matéria: "Tudo aquilo que, no universo, ocupa lugar no espaço" (TOLENTINO et al., 1986, p. 1723);

○ Material: Porção de matéria formada por mais de uma substância; 
Assim, podemos organizar esses dois conceitos no sistema apresentado na Figura 5:

Figura 5 - Forma de Apresentação da Matéria

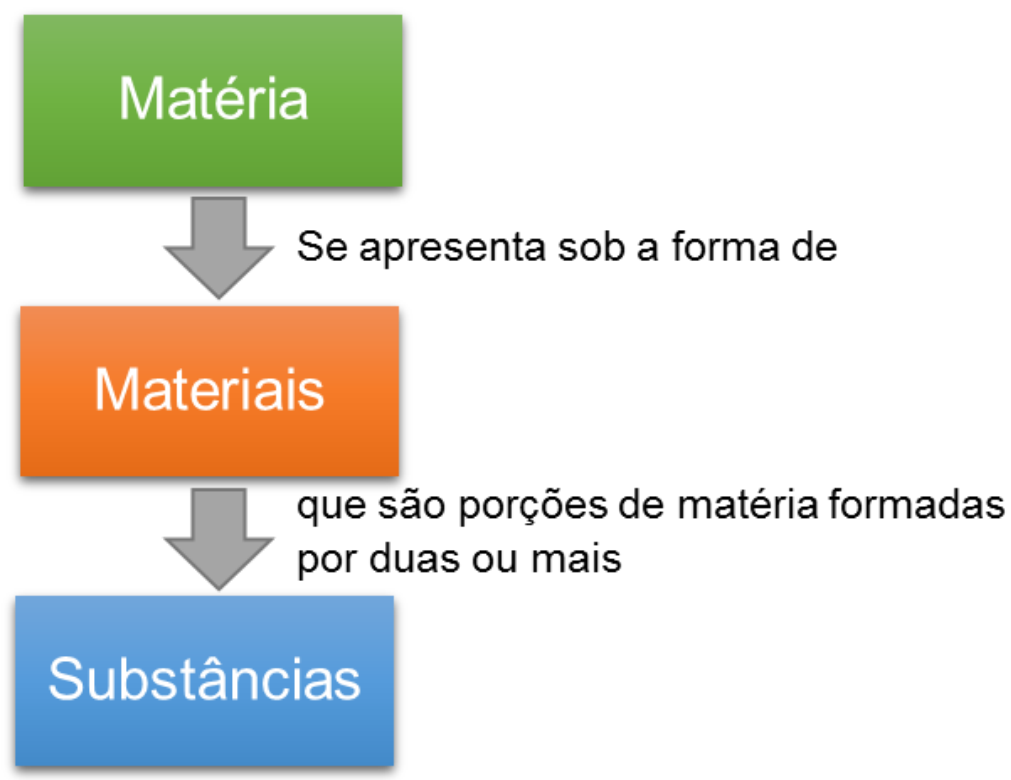

Fonte: Adaptado de Tolentino et al. (1986)

Percebe-se que na organização do sistema conceitual há uma relação lógica estabelecida entre os conceitos envolvidos, no qual o conceito de matéria é supraordenado ao de material, e o de material, ao de substância. Assim, Tolentino e colaboradores ressaltam que nesse sistema os "enunciados conceituais permitem estabelecer com precisão as inter-relações entre os conceitos" (TOLENTINO et al., 1986, p.1724).

Para explicar o conceito de substância, Rocha-Filho et al. (1988) a definiram como sendo uma porção de matéria que possui apenas um tipo de constituinte. $A$ partir desse conceito é apresentado um outro sistema hierárquico que se refere à natureza, à constituição da matéria. Além de substância, eles também definiram constituintes como sendo a "unidade que dá identidade a uma substância" (ROCHAFILHO et al., 1988, p. 417). Podemos ver o sistema conceitual representado na Figura 6. 
Figura 6 - Natureza da Matéria

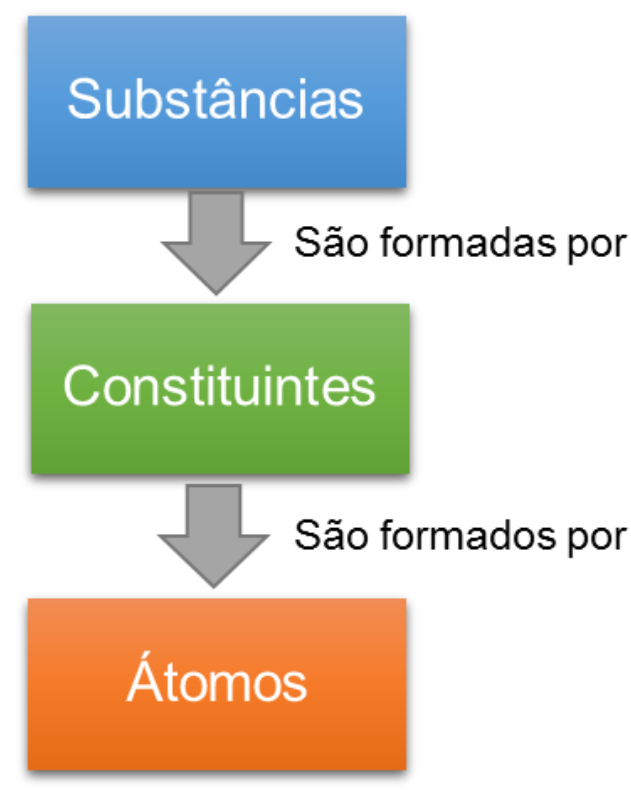

Fonte: Adaptado de Rocha-Filho et al. (1988)

Neste âmbito, ressalta-se a importância do conceito de constituinte, pois a substância não pode ser vista como sendo um conjunto de átomos, tendo propriedades resultantes da soma das características de cada um dos átomos que a compõe, mas sim como formada por unidades, por constituintes, que seria "a entidade que identifica inequivocamente a substância a que define, do ponto de vista epistemológico, como a unidade analítica da Química" (ROCHA-FILHO et al., 1988, p. 417).

Rocha-Filho e colaboradores (1988) explicam que ao auxiliarmos o aluno na compreensão do conceito de constituintes, os átomos passam a ter significado quando fazem parte do constituinte. Isso evita alguns problemas conceituais, pois quando afirmamos que as substâncias são formadas por átomos, excluindo o conceito de constituinte, se poderia afirmar que a água $\left(\mathrm{H}_{2} \mathrm{O}\right)$ e o peróxido de hidrogênio $\left(\mathrm{H}_{2} \mathrm{O}_{2}\right)$ são a mesma substância, ambas formadas por átomos de hidrogênio e oxigênio. Já ao trabalharmos com o conceito de constituintes, as entidades representadas pelas fórmulas $\mathrm{H}_{2} \mathrm{O}$ e $\mathrm{H}_{2} \mathrm{O}_{2}$ conferem identidade para as substâncias água e peróxido de hidrogênio, respectivamente. Assim, constituinte é o "conjunto de átomos que caracteriza uma substância particular" (ROCHA-FILHO et al., 1988, p. 418). Desta forma, é essencial reconhecer os níveis de organização desses conceitos, devendo 
ser entendidos dentro do sistema conceitual: substâncias são formadas por constituintes, e estes formados por átomos.

Os sistemas conceituais apresentados, conforme proposto por Vygotsky, buscam organizar os conceitos de acordo com relações lógicas de subordinação e coordenação. Faz-se necessário que os alunos compreendam cada um dos níveis hierárquicos para evitar que eles apenas memorizem os conceitos apresentados tendo foco apenas no objeto. Deste modo, as aulas favorecerão o desenvolvimento de estruturas superiores de generalização por parte dos estudantes.

Ao pensar em estratégias que possam favorecer a transição entre os níveis apresentados nos sistemas hierárquicos propostos, acreditamos que a utilização de modelos e modelagem podem contribuir para uma melhor compreensão do conhecimento químico.

No ensino fundamentado na modelagem, o professor deverá possibilitar que os estudantes tenham experiências com o alvo (fenômeno, entidade a ser modelada) para construção e testes dos modelos elaborados, favorecendo o contato com o nível macroscópico. O sistema hierárquico apresentado na Figura 5 - Formas de Apresentação da Matéria - se situa nesse nível, e pode ser trabalhado a partir de experimentos demonstrativos-investigativos para trazer para o contexto de salas de aula os fenômenos a serem modelados. No nível submicroscópico, são construídos modelos para representar, explicar e fazer previsões sobre o fenômeno observado, podendo ser utilizados modelos concretos, animações computacionais, desenhos, dentre outros (MENDONÇA, 2011). O segundo sistema hierárquico apresentado, Natureza da Matéria (Figura 6), se situa nesse nível, sendo necessário a utilização de modelos para representar os constituintes (e consequentemente átomos) presentes nas substâncias. Assim, no próximo capítulo serão apresentados: o conceito de modelos, qual a importância destes para as Ciências e para o ensino de Química, e um modelo proposto por Justi e Gilbert (2002) que pode favorecer no desenvolvimento de estratégias de ensino fundamentadas na modelagem. 


\section{A UTILIZAÇÃO DE MODELOS E MODELAGEM NO ENSINO DE QUÍMICA}

As Orientações Complementares aos Parâmetros Curriculares Nacionais $(\mathrm{PCN}+)$ nos apresentam conjuntos de competências a serem trabalhadas e desenvolvidas no processo ensino-aprendizagem das chamadas Ciências da Natureza e Matemática, e dentre elas podemos destacar a de investigação e compreensão. Para o desenvolvimento dessa competência, um dos pontos apresentados é o Modelos explicativos e representativos, sendo para isso necessário "reconhecer, utilizar, interpretar e propor modelos explicativos para fenômenos ou sistemas naturais ou tecnológicos" (BRASIL, 2002, p. 30).

Porém, pesquisas realizadas por Justi e Gilbert $(2003)^{8}$, apud Justi (2011), evidenciam que muitos docentes não compreendem o que são modelos, e ao serem questionados sobre essa definição, muitos respondem que modelos são "cópias" ou "reproduções" da realidade e outros admitem nunca terem refletido sobre isso. Essa falta de compreensão dos conceitos de modelos, modelagem e de conhecimento sobre como utilizá-los no ensino de Química, faz com que professores não busquem desenvolver estratégias que visem o desenvolvimento da capacidade dos estudantes de reconhecerem a importância dos modelos, como eles são utilizados nas Ciências, como propor modelos, dentre outras.

Nesse âmbito, antes de buscarmos entender como utilizar modelos e modelagem no processo ensino-aprendizagem de Química visando o desenvolvimento da competência citada, é importante apresentarmos uma reflexão do que são modelos e da importância deles para o conhecimento científico.

Existem diversas definições para modelos em diferentes áreas da Ciência, e Justi (2011) traz a seguinte definição geral: "um modelo é uma representação parcial de uma entidade, elaborado com um, ou mais objetivo(s) específico(s) e que pode ser modificado" (p. 211). Essa entidade que pode ser um objeto, um processo, uma ideia, é parcialmente representada pelo homem e, portanto, não é a realidade e nem uma cópia dela.

Como já dito anteriormente, essa definição que pode parecer simples, não é compreendida por grande parte dos professores de Química. Esse quadro se reflete

8 JUSTI, R.; GILBERT, J. K. Teachers' views on the nature of models. International Journal of Science Education, London, 25, 11, p. 1369-1386, 2003. 
nas concepções dos estudantes sobre diversos conceitos, como quando se deparam com o estudo dos modelos atômicos, em que alguns acreditam que os modelos apresentados são ampliações dos átomos ou que o modelo mais atual está pronto e acabado (JUSTI, 2011). Face a esse problema, é importante que docentes e discentes compreendam o que são modelos, como são construídos, suas finalidades e também limitações. A partir dessas discussões possibilita-se um conhecimento mais amplo sobre a natureza da ciência, e como o conhecimento científico, sendo uma construção humana, é elaborado e modificado.

Em seus trabalhos, Justi (2011), e em conjunto com Gilbert (2002), identificaram diferentes funções para a utilização de modelos em Química, sendo as principais:

$>$ Facilitar no entendimento de fenômenos complexos, por meio de representações simplificadas;

> Possibilitar a visualização de entidades abstratas, tornando possível interpretar dados experimentais, permitindo 0 desenvolvimento de explicações científicas para esses resultados e facilitando a comunicação para a comunidade científica (JUSTI, GILBERT, 2002);

> Favorecer abstração de entidades ainda impossíveis de se visualizar, além de servirem para fornecer uma base para previsão de funções mais complexas;

> “Fundamentar a proposição e a interpretação de experimentos" (JUSTI, 2011, p. 212);

$>$ "Ser um mediador entre a realidade modelada e teorias sobre ela" (JUSTI, 2011, p. 212).

Assim, os modelos são utilizados em Química para desempenhar uma série de funções, além das especificadas anteriormente. A utilização de modelos é fundamental nessa área, pois essa é uma ciência de abstrações. Ao observar fenômenos no nível macroscópico, o químico busca explicá-los no nível submicroscópico, utilizando-se da linguagem científica e de modelos representativos.

Porém, para Gilbert (2004), uma das dificuldades de se discutir modelos no ensino de Ciências se deve a forma como são originados diferentes modelos. Sendo estes criados pela mente humana, primeiramente são elaborados a partir de representações pessoais, inacessíveis aos outros. Estas representações, que podem ser criadas individualmente ou em grupo, são chamadas de modelos mentais. Quando 
uma versão do modelo mental é exposta para outras pessoas, ele passa a se chamar de modelo expresso. Quando um grupo social, que pode ser uma classe escolar, concorda com um modelo expresso, tem-se um modelo consensual. Caso esse grupo social seja de cientistas que se utiliza de um modelo consensual para o desenvolvimento do conhecimento científico, ele será denominado modelo científico. Por fim, quando um modelo científico que foi aceito em outro contexto é substituído, ele passa a se chamar modelo histórico.

Uma outra dificuldade também apresentada por Gilbert (2004) e Justi (2011) é que os modelos podem ter diferentes formas de representação. Para tornar um modelo mental em modelo expresso, é utilizado pelo menos um dos cinco modos de representação, podendo ser:

- o modo concreto (ou material), que é tridimensional, feito de material resistente e possível de ser manuseado;

- o modo verbal, no qual são descritas as entidades e suas relações, e as relações entre elas e os modelos. Pode ser expresso por meio da fala ou da escrita;

- o modo simbólico, que se utiliza de símbolos, expressões matemáticas, equações químicas e fórmulas químicas;

- o modo visual, que faz uso de gráficos, diagramas, animações, podendo se utilizar de programas computacionais para produzir esses modelos;

- e o modo gestual, no qual podem ser utilizadas as partes do corpo humano e seus movimentos para representar diferentes fenômenos e entidades.

Porém, mesmo com essas dificuldades, vimos que os $\mathrm{PCN}+$ recomendam que os estudantes desenvolvam essa habilidade, e especificamente na área da Química ressaltam que na educação básica eles devem ser capacitados a:

- Reconhecer modelos explicativos de diferentes épocas sobre a natureza dos materiais e suas transformações; por exemplo, identificar os principais modelos de constituição da matéria criados ao longo do desenvolvimento científico.

- Elaborar e utilizar modelos macroscópicos e microscópicos para interpretar transformações químicas;

- Reconhecer, nas limitações de um modelo explicativo, a necessidade de alterá-lo;

- Elaborar e utilizar modelos científicos que modifiquem as explicações do senso comum. (BRASIL, 2002, p. 91) 
Assim, esse documento recomenda que os estudantes compreendam o que são modelos científicos e modelos históricos e, ainda, desenvolvam a capacidade de construir e utilizar modelos.

Cabe ressaltar que, em sala de aula, são ensinados modelos curriculares, simplificações de modelos científicos, pois estes são muitas vezes extremamente complexos para serem entendidos na educação básica, sendo os modelos curriculares suficientes para o entendimento dos fenômenos ali discutidos. Para explicar os modelos curriculares, o professor se utiliza de modelos de ensino, que são representações utilizadas para propiciar o entendimento dos modelos curriculares, sendo os principais: representações (2D e 3D), simulações computacionais e analogias (GILBERT, 2004).

Mesmo percebendo a importância dos modelos para as Ciências, poucos trabalhos discutem como as habilidades de modelagem podem ser desenvolvidas. Morrison e Morgan (1999) explicam que existem poucos artigos apresentando aspectos relacionados à construção de modelos. Para elas, isso pode ser reflexo da visão de pesquisadores que acreditam que a capacidade de modelar é algo a ser aprendido na prática, não ensinado, e que necessitam de habilidades criativas para seu desenvolvimento. Alguns ainda argumentam que a modelagem é um processo que não é suscetível a regras gerais.

Essas autoras defendem que o aprendizado pode se dar observando modelos, mas, pode-se aprender ainda mais por meio de atividades de modelagem. Além delas, autores como: Erduran e Duschl $(2004)^{9}$, Millar e Osborne (1998) ${ }^{10}$ apud Mendonça (2011) tem defendido um ensino no qual os estudantes tenham uma visão maior da natureza da Ciência, podendo perceber como os modelos são elaborados e avaliados na construção do conhecimento científico, e não apenas conheçam as abrangências e limitações dos modelos curriculares.

Deste modo, Justi e Gilbert (2002), a partir dos estudos de Clement (1989) desenvolveram um "modelo de modelagem" apresentando e discutindo as diferentes etapas para construção de modelos. Esses autores explicam que esse processo, a pesar de ser dinâmico e criativo, apresenta etapas inerentes a atividades de

\footnotetext{
9 Referência citada por Mendonça (2011), disponível em: Erduran, S., \& Duschl, R. A. (2004). Interdisciplinary Characterizations of Models and the Nature of Chemical Knowledge in the Classroom. Studies in Science Education, 40, 105-138.

10 Referência citada por Mendonça (2011), disponível em: Millar, R., \& Osborne, J. (1998). Beyond 2000: Science education for the future. London: King's College, London School of Education.
} 
modelagem em geral. Para entender o esquema proposto por Justi e Gilbert (2002), primeiramente serão apresentadas as ideias de Clement (1998) apud Mendonça (2011) sobre os processos de modelagens realizados pelos cientistas, que foram utilizadas na elaboração do diagrama apresentado a seguir.

Clement (1989) ${ }^{11}$, citado por Mendonça (2011), explica que os modelos são elaborados pelos cientistas em um processo cíclico denominado de ciclo GAM (geração, avaliação e modificação de modelos). Nesse processo, um modelo inicial é criticado e revisado por um grupo de cientistas, dando origem a outros modelos cada vez mais aprimorados e complexos. Assim, depois que o modelo foi elaborado, é avaliado se ele cumpre o objetivo para o qual foi proposto. Quando a sua utilização leva a problemas complexos, ele deve ser descartado e é proposto um novo. Caso gere problemas simples, ele passa por modificações que solucionem essas limitações e novamente avalia-se este modelo. O ciclo GAM é representado na Figura 7:

Figura 7 - Ciclo GAM (Clement, 1989)

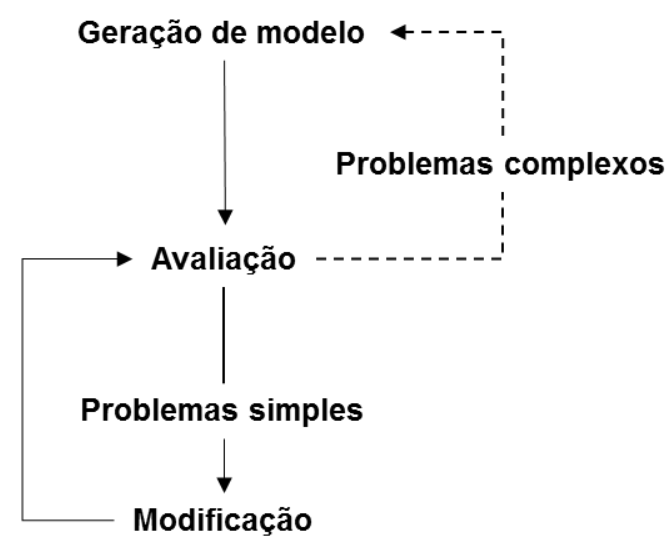

Fonte: Mendonça (2011, p. 25)

Clement (2000) ${ }^{12}$ apud Mendonça (2011), apresenta ainda uma estrutura para explicar como se dá o caminho da aprendizagem por meio de modelos. Para o autor, o objetivo do ensino é atingir um modelo alvo, que pode ou não ser o modelo científico consensual ${ }^{13}$. Ao observar o fenômeno em questão, os estudantes irão raciocinar e

\footnotetext{
11 Disponível em: Clement J. (1989). Learning via Model Construction and Criticism - Protocol evidence on sources of creativity in science. In J. A. Glover, R. R. Ronning \& C. R. Reynolds (Eds.), Handbook of Creativity (pp. 341-381). New York: Plenum.

12 Disponível em: Clement, J. (2000). Model based learning as a key research area for Science education. International Journal of Science Education, 22(9), 1041-1053.

${ }^{13}$ Diferentemente de Clement (1989) entendemos que na educação básica não são ensinados modelos científicos consensuais, mas sim modelos curriculares.
} 
apresentar ideias prévias, que podem ser concepções alternativas e conceitos coerentes e/ou incoerentes sobre a situação analisada. Ao logo do processo de aprendizagem, os estudantes passarão por modelos intermediários que serão unidades de construção para o desenvolvimento do modelo alvo, conforme é representado pela Figura 8:

Figura 8 - Aprendizagem por meio de modelos proposto por Clement (2000)

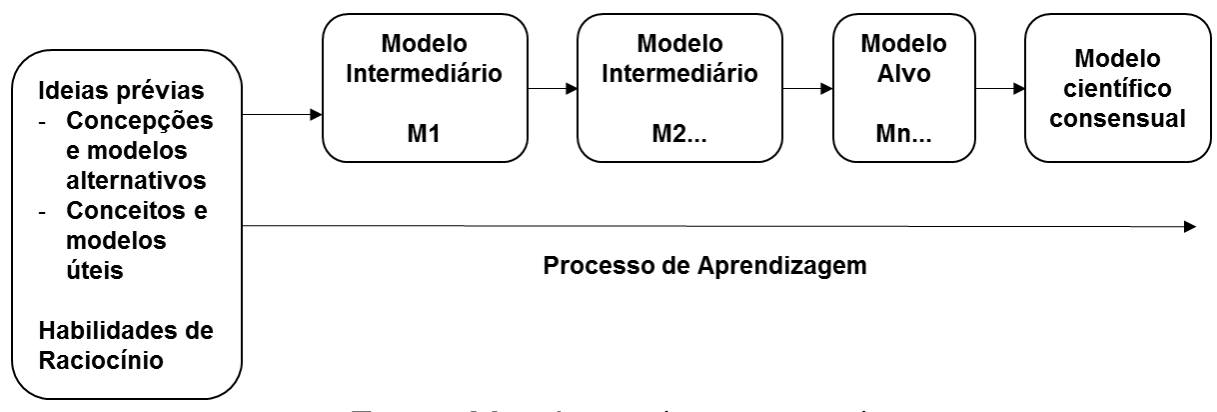

Fonte: Mendonça (p. 26, 2011)

A partir dessas ideias de Clement (1989, 2000) apud Mendonça (2011) sobre a elaboração de modelos pelos cientistas, Justi e Gilbert (2002) propõe um modelo mais complexo que permite discutir as etapas desse processo e as relações entre elas. $O$ diagrama é chamado de "modelo de modelagem", e é apresentado a seguir (Figura 9). Cada uma de suas etapas é discutida posteriormente.

Observando o diagrama, percebe-se que ele é composto de quatro etapas. A primeira delas, que é representada como etapa 1, corresponde a produção de um modelo mental. Para realização dessa atividade é fundamental que se tenha conhecimento ou que se definam os objetivos para os quais tal modelo será elaborado. No ensino de Química por meio da modelagem, o professor deve deixar claro esses objetivos em seu planejamento e ter conhecimento sobre modelo curricular que deseja discutir com os estudantes. Os modelos elaborados em sala de aula nem sempre irão corresponder ao modelo curricular e o professor não deve ficar preso a ele como sendo o único modelo "correto", pois os estudantes podem produzir modelos diferentes que sejam coerentes e com poder de previsão adequados tal como os curriculares (MENDONÇA, 2011). O professor deve estar ciente que os alunos possuem vários conhecimentos prévios que servirão para a elaboração do modelo e também deve estar atento as possíveis concepções alternativas que os estudantes possam vir a ter sobre o fenômeno que estarão modelando. Também é importante 
que os estudantes tenham conhecimento de alguns conceitos que darão suporte a produção do modelo (ALVES, 2012).

Figura 9 - Modelo para o processo de construção de modelos

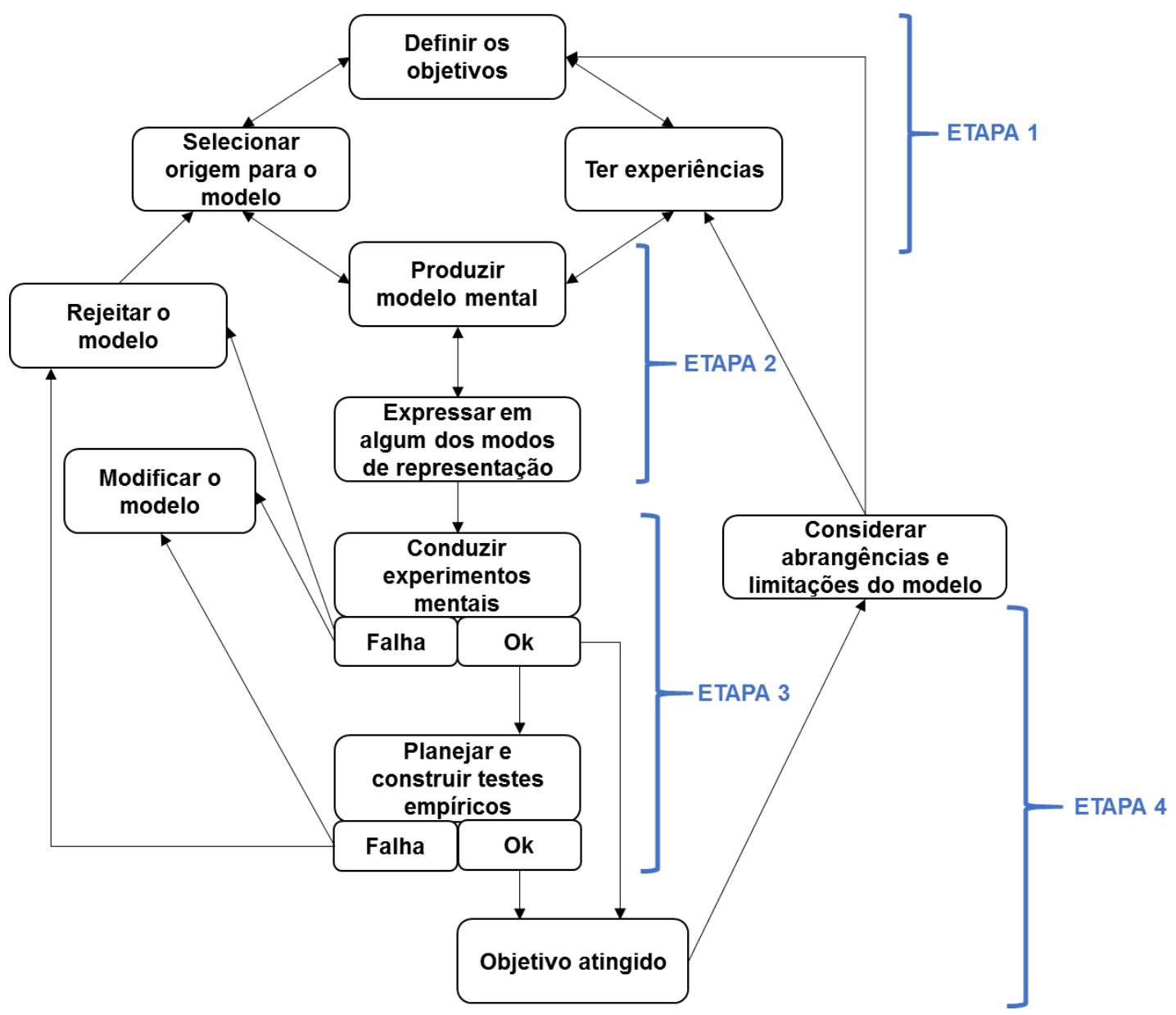

Fonte: Justi e Gilbert (2002) apud Mendonça (2011, p. 27)

Sabendo dos objetivos do modelo que será elaborado, os participantes devem ter experiências, fazer observações iniciais da entidade a ser modelada. Essas podem ser diretas ou indiretas, quantitativas ou qualitativas, podem partir de experiências empíricas, de referências da literatura ou de informações dos próprios indivíduos (JUSTI, 2006). Enquanto essas experiências são vivenciadas, também é selecionada a origem para o modelo, momento em que ocorre a seleção dos aspectos da realidade que serão utilizados para descrever a entidade a ser modelada.

Assim, a etapa 1 corresponde a essas três subetapas: definição dos objetivos, ter experiências e origem para o modelo. Estas, conjuntamente com a criatividade e o raciocínio crítico dos participantes, levarão à formação de um modelo mental inicial. 
Depois de elaborar um modelo mental, deve-se decidir qual é a forma mais adequada de torná-lo um modelo expresso. Dentre as diversas formas: concreta, visual, verbal, simbólica, deve-se escolher qual (ou quais) serão utilizadas para representação (etapa 2). Em sala de aula, Justi (2006) explica que o professor pode (1) deixar que os estudantes escolham a forma de representação; (2) escolher uma forma de representação para que todos os estudantes utilizem; ou (3) mostrar diferentes formas de representação e propor que eles escolham a que melhor favoreça na comunicação de suas ideias. As opções (1) e (3) possibilitam que os estudantes reflitam a partir de seus próprios critérios sobre qual a melhor maneira de tornar seu modelo expresso e ainda exercitem a criatividade. Ao utilizar a opção (2), o professor deve deixar claro o porquê de escolher tal forma de representação e que existem várias outras, para que os estudantes não pensem que aquele é o único modo existente de se expressar um modelo.

Justi (2006) recomenda que, em sala de aula, cada aluno individualmente elabore seu próprio modelo mental para depois compartilhá-lo com o seu grupo. Os alunos irão discutir entre eles quais as vantagens e contradições dos modelos apresentados, e o professor deve escutar suas ideias e fazer perguntas que favoreçam: a reflexão sobre as diferentes formas de expressão dos modelos propostos; a negociação de ideias visando o desenvolvimento das que parecerem mais interessantes; situações em que os estudantes verifiquem a validade de seus modelos. Nesse processo ocorrerá a construção de um modelo consensual para cada grupo de estudantes.

A etapa 3 é a comprovação dos modelos. Neste momento, os modelos consensuais elaborados são testados por meio de experimentos mentais ou experimentos empíricos. Justi (2006) explica que a decisão de utilizar apenas um ou ambos e também a ordem em que serão realizados vai depender dos recursos disponíveis e dos conhecimentos prévios dos estudantes. Nessa etapa, caso o professor opte por utilizar experimentos empíricos, este deve ter natureza investigativa tendo a oportunidade de mostrar aos estudantes que um experimento não é apenas uma receita que o cientista executa, mas uma atividade que exige reflexão e conhecimentos, sendo fundamental na elaboração e evolução dos modelos científicos. Caso o modelo proposto falhe apresentando contradições ao passar por esses testes, ele pode ser modificado e novamente testado. Porém, se for percebido 
que os problemas apresentados são graves não sendo possível realizar modificações para adequá-lo, deve-se rejeitar o modelo e propor um novo.

É importante ressaltar que os modelos consensuais elaborados nos diferentes grupos devem ser compartilhados com a turma, pois esta é uma atividade semelhante a que os pesquisadores realizam ao socializarem seus modelos para julgamento pela comunidade científica. Nesse momento, os estudantes podem trazer críticas e contribuições aos modelos uns dos outros, podendo modificá-los ou abandoná-los caso as incoerências apresentadas não possam ser solucionadas (MENDONÇA, 2011). Pela socialização, os estudantes têm contato com os diferentes modelos produzidos para representar uma mesma entidade e ainda podem elaborar um único modelo consensual a partir dos que foram propostos. Nessa fase, o professor deve participar das discussões como no momento anterior, porém não deve julgar os modelos apresentados como certos ou errados e sim avaliar as suas capacidades de previsão e explicação para a entidade modelada (JUSTI, 2006).

Os modelos que tiverem êxito nas três primeiras etapas são os que conseguiram atingir aos objetivos pré-estabelecidos, e a etapa 4 é o momento de avaliação dos modelos consensuais. Nessa fase, serão discutidas as limitações e abrangência dos modelos propostos, avaliando-os com relação aos objetivos e por meio de teste desses modelos em outras situações.

Essas quatro etapas apresentadas se inter-relacionam, acarretando influências umas nas outras. Justi (2010) elaborou o seguinte esquema (Figura 10), mostrando as quatro etapas descritas, para ser utilizado pelo professor na elaboração de estratégias de ensino fundamentado na modelagem.

Assim, o ensino fundamentado na modelagem deve possibilitar que os estudantes vivenciem todas essas etapas apresentadas, além de compreenderem o que são modelos e a importância deles para a Ciência. 
Figura 10 - Relação entre as principais etapas envolvidas na modelagem

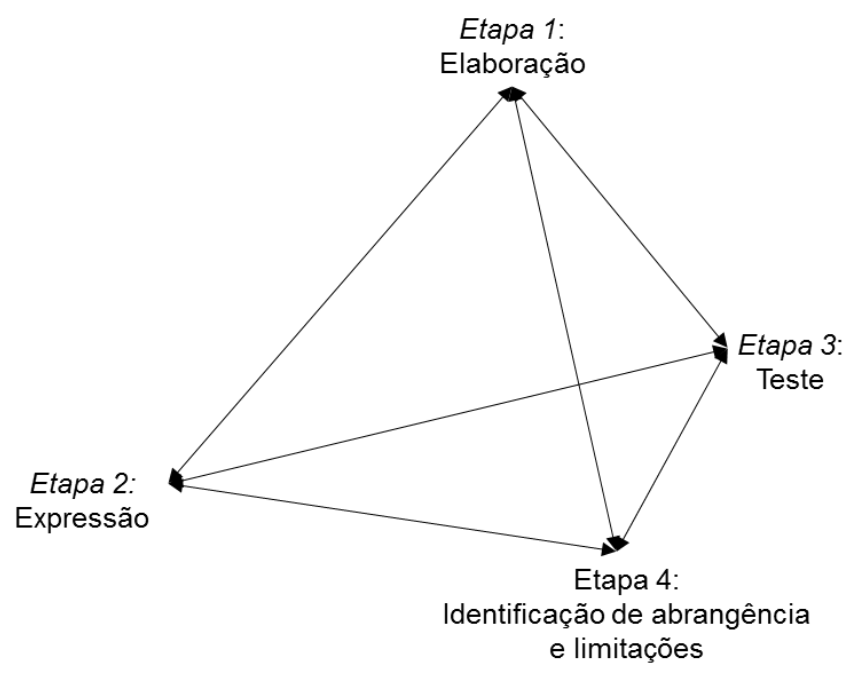

Fonte: Justi (2010) citado por Justi (2010b, p. 223) ${ }^{14}$ com modificações

Para utilização de modelos e modelagem em nossa pesquisa, foi organizado um esquema apresentado na Figura 11, baseado no diagrama proposto por Justi e Gilbert (2002), com as etapas trabalhadas em nossa proposta.

Na figura 11, a primeira etapa apresentada é a elaboração do modelo, em que, a partir das observações macroscópicas de atividades demonstrativo-investigativas, os estudantes elaboraram modelos para representar como a Ciência explica os fenômenos observados (nível submicroscópico), esses modelos foram avaliados (testados) e, quando não atingiram determinado objetivo, foram modificados e, passaram por essas etapas novamente, até que foi utilizado um modelo adequado na explicação do fenômeno em questão.

${ }^{14} \mathrm{JUSTI}, \mathrm{R}$. Las concepciones de modelos de los alumnos y el aprendizaje de las ciencias. Un relación compleja en la enseñanza de las ciencias.In: CAAMAO, A. (Ed.). Didáctica de la física y química. Barcelona: Editorial Graó, 2010. 
Figura 11 - Etapas desenvolvidas nas atividades de modelagem

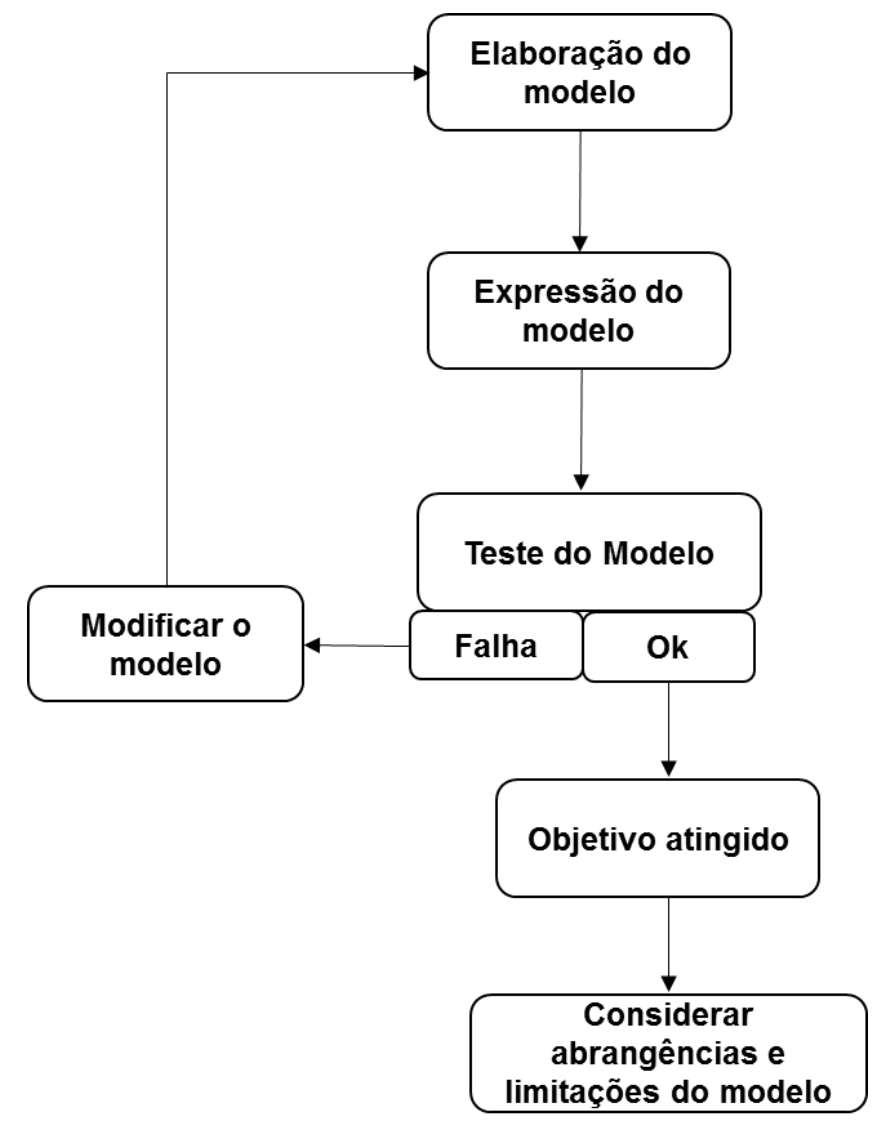

Fonte: Adaptado de Justi e Gilbert (2002) apud Mendonça (2011, p. 27)

Diante do exposto, acreditamos que estratégias que envolvam a discussão dos três níveis conhecimento químico a partir da apresentação dos sistemas conceituais "Formas de Apresentação da Matéria" (Figura 5) e "Natureza da Matéria" (Figura 6) podem contribuir para um ensino mais aprofundado e significativo da Química, indo além da memorização de fatos e conceitos. A partir das reflexões apresentadas, o trabalho será desenvolvido utilizando o ensino fundamentado na modelagem para auxiliar os estudantes na transição entre os níveis submicroscópico e representacional. Com isso buscou-se contribuir para que eles compreendessem aspectos relacionados a natureza da Ciência, que é construída e modificada utilizando-se de modelos, e desenvolvessem habilidades de visualizar e representar os constituintes das substâncias e consequentemente entenderem os conceitos científicos que foram apresentados. 


\section{Percurso Metodológico}

A partir dos estudos apresentados na fundamentação teórica deste trabalho, nesse capítulo será detalhado o percurso metodológico para se analisar as possíveis contribuições do uso de sistemas conceituais hierárquicos na transição entre os três níveis de representação do conhecimento químico e da utilização de atividades que envolvem modelos e modelagem para a transição entre os níveis submicroscópico e representacional.

O diagrama da Figura 12 apresenta nossas estratégias que foram utilizadas na metodologia visando favorecer o aprendizado de conceitos químicos relacionados ao tema atmosfera.

Figura 12 - Sistema conceitual e estratégias de abordagem para conceitos químicos

Mundo Macroscópico

- Experimentos demonstrativosinvestigativos;

- Observação de fatos e fenômenos.

Mundo Submicroscópico

- Como a Química explica e representa os fatos e fenômenos;

- Modelos e modelagem;

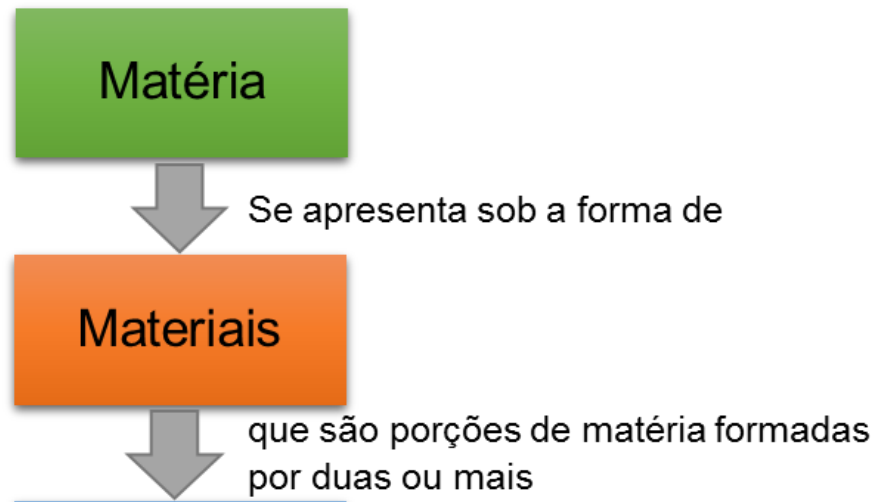

\section{Substâncias}

São formadas por

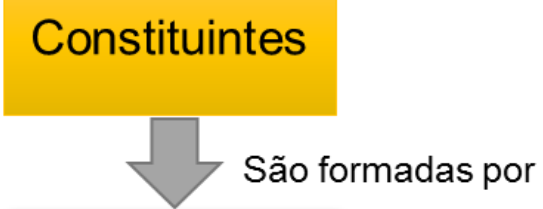

Átomos

Fonte: Adaptado de Tolentino et al. (1986) e Rocha-Filho et al. (1988) 
Cabe ressaltar uma importante característica do presente trabalho que é a de ser uma pesquisa aplicada, tendo como foco analisar se a utilização das estratégias apresentadas pode favorecer no processo ensino-aprendizagem de conceitos químicos. Os resultados obtidos na aplicação da proposta foram analisados de forma qualitativa, sendo observadas as transcrições realizadas ao longo das atividades e os modelos desenvolvidos pelos estudantes, e quantitativa, com a utilização de questionários prévios e pós-encontros, sendo os dados obtidos organizados em diferentes categorias de análise.

A partir dos resultados foi elaborada a proposição, apresentada no Apêndice A, que é um módulo didático para professores que queiram trabalhar os conceitos químicos utilizando sistemas conceituais e modelos e modelagem na discussão dos três níveis do conhecimento químico propostos por Johstone (2009), para o ensino do tema gases. Esta proposição busca mostrar como podem ser desenvolvidas atividades que facilitem a compreensão de cada um dos três níveis utilizando sistemas conceituais e modelos e modelagem. Espera-se que com ela o professor possa utilizar esses conhecimentos em seu planejamento não só para o estudo dos gases, mas também para o desenvolvimento de estratégias para o ensino de outros conteúdos.

Assim, como utilizamos em nosso recurso metodológico uma abordagem por temas e a experimentação em aulas de Química, antes de adentrarmos no percurso em si, nos próximos tópicos serão realizadas breves discussões sobre essas duas estratégias adotadas: o ensino por temas e o uso da experimentação no ensino de Química enfocando na utilização de experimentos demonstrativos-investigativos, para em seguida serem discutidas a metodologia e análise dos dados da presente pesquisa.

\subsection{O ENSINO POR TEMAS}

Ao ensinarmos Química na educação básica surgem diversas questões, como: Quais conteúdos devemos trabalhar? Como podemos organizar esses conteúdos de forma a favorecer o processo ensino-aprendizagem? Essas indagações surgem principalmente por observarmos que os conteúdos que discutimos são muitas vezes 
fragmentados, inadequados e que não se fazem presentes na vida dos estudantes (CHASSOT, 2013).

Tendo em vista esses problemas, as Diretrizes Curriculares Nacionais Gerais da Educação Básica (2013) propõem que o conhecimento seja trabalhado de forma contextualizada e interdisciplinar, sugerindo como estratégia a utilização dos temas geradores, proposta que surge a partir das ideias de Paulo Freire.

Para Freire (2005), o ensino não deve estar focado no aprendizado mecânico, mas sim em processo que envolva o diálogo entre os participantes. Freire defende uma educação que não se limite à memorização de conceitos sem sentido, e sim, tenha finalidade emancipadora, problematizadora e de caráter reflexivo. Nessa perspectiva, os conteúdos a serem discutidos na escola devem surgir de temas sociais próprios da comunidade, de seus reais problemas e necessidades. Estes são chamados por Freire de "temas geradores" e sua proposição deve partir dos anseios da comunidade, sendo construções coletivas que surgem a partir de situações concretas vivenciadas por aquele grupo (FREIRE, 2005):

É importante enfatizar que o tema gerador não se encontra nos homens isolados da realidade, nem tampouco na realidade separada dos homens. Só pode ser compreendido nas relações homem-mundo [...] Investigar o tema gerador é investigar, repitamos, o pensar dos homens referido à realidade, é investigar seu atuar sobre a realidade, que é sua práxis (FREIRE, 2005, p. 114).

Santos (2007), incorporando as ideias de Freire, recomenda que o conteúdo químico seja trabalhado por meio de temas CTS (Ciência-Tecnologia-Sociedade). Para o autor, a discussão de conteúdos deve estar associada a aspectos sociais, tecnológicos, econômicos e éticos, de modo a favorecer a formação de cidadãos conscientes da realidade em que estão inseridos. Esse diálogo possibilita que os estudantes tenham um olhar mais crítico sobre o conhecimento científico, podendo influenciá-los na tomada de decisão sobre questões que envolvam Ciência e Tecnologia:

Inserir a abordagem de temas CTS no ensino de ciências com uma perspectiva crítica significa ampliar o olhar sobre o papel da ciência e da tecnologia na sociedade e discutir em sala de aula questões econômicas, políticas, sociais, culturais, éticas e ambientais. Essas discussões envolvem valores e atitudes, mas precisam estar associadas à compreensão conceitual dos temas relativos a esses aspectos sociocientíficos, pois a tomada de decisão implica a 
compreensão de conceitos científicos relativos à temática em discussão. (SANTOS, 2007, p. 10)

Os PCN+ também recomendam o uso de temas no ensino de Ciências. Os chamados temas estruturadores seriam uma forma de organização dos conteúdos em um contexto visando atingir as competências gerais ali apresentadas (BRASIL, 2002). Assim:

Cada disciplina ou área de saber abrange um conjunto de conhecimentos que não se restringem a tópicos disciplinares ou a competências gerais ou habilidades, mas constituem-se em sínteses de ambas as intenções formativas. Ao se apresentarem dessa forma, esses temas estruturadores do ensino disciplinar e seu aprendizado não mais se restringem, de fato, ao que tradicionalmente se atribui como responsabilidade de uma única disciplina. (BRASIL, 2002, p. 13)

Deste modo, segundo os $\mathrm{PCN}+$, a utilização dos temas estruturadores pode possibilitar uma maior interdisciplinaridade entre as diferentes áreas do conhecimento, além de uma maior contextualização. Por exemplo, ao sugerir o tema Biosfera para ser trabalhado em Química, pode-se trabalhar interdisciplinarmente com a Biologia, e ambas devem trabalhar os conteúdos enfocando em suas respectivas áreas e interrelacionando os conhecimentos entre elas.

Um dos temas sugeridos nos PCN+ é a Química e Atmosfera, que segundo o documento, deve ser trabalhado para que os estudantes possam conhecer: as substâncias presentes nesse ambiente; as reações químicas; os processos de extração e produção de substâncias a partir desses materiais; e as relações CTS envolvidas na utilização deste pelo ser humano, ressaltando os impactos ambientais, tecnológicos, econômicos e sociais por ele ocasionados.

Em nosso trabalho, optamos por utilizar o tema Química e Atmosfera, pois como nosso objeto é auxiliar na transição entre os três níveis do conhecimento químico (macroscópico, submicroscópico e representacional) utilizando estratégias que envolvam modelos e modelagens, a utilização desse tema pode facilitar o entendimento dos estudantes sobre os constituintes das substâncias. Como os constituintes dessas substâncias são formadas por um número menor de átomos, a compreensão dos modelos de natureza atômico-molecular torna-se menos complexa e mais acessível aos estudantes. 
Em nossa pesquisa, utilizaremos experimentos demonstrativos-investigativos para possibilitar a observação de fenômenos que se relacionam com o tema atmosfera.

\subsection{A EXPERIMENTAÇÃo NO ENSINO de QuímicA}

A utilização da experimentação no ensino de Ciências é bastante recomendada por pesquisadores da área e também pelos documentos oficiais ( $\mathrm{PCN}, \mathrm{PCN}+$, dentre outros), visando propiciar uma constante articulação entre fenômeno e teoria, além de um ensino mais contextualizado e interdisciplinar (SILVA, MACHADO, TUNES, 2011).

Porém, com relação a utilização desse recurso no contexto escolar, críticas apontam que as abordagens tradicionais de atividades experimentais no Ensino Médio pouco contribuem para o entendimento na natureza da Ciência e de conhecimentos científicos. Exemplo disso é o discurso utilizado para se justificar a utilização dessas atividades em aulas de Químicas, que seria o de possibilitar que os estudantes "observem a teoria na prática". Essa ideia simplista da experimentação é reflexo da forma como muitos professores entendem a Ciência - algo que está na natureza, pronto para ser descoberto (SILVA, ZANON, 2000).

Outro problema observado com relação a experimentação no ensino, é que a maioria das estratégias utilizadas pelos professores da educação básica se assemelham à experimentação desenvolvida nos laboratórios de ensino das universidades: é entregue um roteiro pré-estabelecido e os estudantes realizam as etapas para atingir um objetivo definido (PEREIRA, 2008). Para Hodson (1994), essas estratégias tornam a atividade desmotivadora e entediante para os estudantes, que nessa fase buscam autonomia. Ele acredita que, na verdade, essas atividades deveriam promover desafios e discussões sobre os fenômenos em questão, motivando os alunos na busca por respostas.

Quando as atividades são utilizadas dessa forma omite-se o entendimento da Ciência como construção humana, como verdades transitórias, e favorecem que se perpetue a visão positivista ingênua do conhecimento científico - resultado de um único método, incontestável. 
Silva, Machado e Tunes (2011) explicam que para se realizar uma atividade experimental com uma natureza investigativa, deve-se buscar observar a capacidade de generalização e previsão de uma teoria. O professor ao mostrar um experimento para os estudantes não está provando a veracidade da teoria, mas sim testando sua capacidade de generalização. Quanto maior for a quantidade de fenômenos que puderem ser explicados por uma mesma teoria, maior sua capacidade de generalização. Já sua capacidade de previsão se refere aos fenômenos que podem ser previstos por determinada teoria antes mesmo de serem observados.

Assim, uma sugestão de atividade experimental que pode ser utilizada nessa perspectiva são as demonstrativas-investigativas, estratégia que será utilizada na presente pesquisa. Nessas atividades, o professor apresenta em sala de aula, fenômenos simples que permitem a introdução de conceitos teóricos que se relacionam com o fenômeno observado.

Para a condução de um experimento demonstrativo-investigativo, inicialmente é feita uma pergunta que desperte curiosidade nos estudantes. O professor deve fazer o questionamento e ouvir as respostas para que sejam levantadas as concepções prévias dos estudantes. Além disso, essa pergunta possibilita uma maior participação e interesse dos alunos pela atividade que será realizada.

A próxima etapa é a realização do experimento pelo professor. Os alunos devem observar e descrever o que é visualizado na atividade experimental (macroscópico), o professor deve explicitar a teoria científica, como a Ciência explica o que ocorreu (submicroscópico), e, por fim, representar, utilizando a linguagem química - símbolos, fórmulas, modelos representacionais, equações - o fenômeno em questão. Silva, Machado e Tunes (2011) recomendam ainda, que após a observação macroscópica, o professor solicite que os estudantes pensem em possíveis hipóteses que expliquem o que ocorreu na atividade experimental.

Para o fechamento da aula, o professor deve responder a pergunta inicial, e incluir a interface ciência-tecnologia-sociedade - CTS, que seriam possíveis implicações no âmbito social, tecnológico, econômico, ambiental, relacionadas a atividade desenvolvida (SILVA, MACHADO, TUNES, 2011).

Os roteiros experimentais de algumas atividades demonstrativas-investigativas relacionadas ao tema atmosfera estão disponíveis no módulo didático da presente pesquisa (Apêndice A). 


\subsection{DescriçÃo das estratéGias metodolóGicas}

A presente pesquisa foi realizada em uma turma de $1^{\circ}$ ano do Ensino Médio de uma escola da Rede Pública de Educação do Distrito Federal. Foram realizadas seis aulas duplas (aproximadamente 100 minutos de duração) e a coleta de dados foi feita por meio de questionários prévios e posteriores as aulas, gravações de áudio das discussões realizadas, observação de fotos e desenhos dos modelos propostos pelos estudantes, além de anotações em diário de campo na qual foram relatadas situações relevantes que ocorreram no contexto de sala de aula.

\subsubsection{Primeiro encontro}

Antes de começar a aula, os estudantes responderam a um questionário inicial com as seguintes perguntas:

(1) para você, o que é atmosfera?;

(2) para você, o que é o ar?;

(3) do que é constituído o gás nitrogênio, o gás oxigênio e o gás hidrogênio?;

Essas perguntas foram realizadas tendo como objetivo levantar as concepções prévias dos estudantes sobre o assunto que seria abordado.

O primeiro encontro, chamado de "A Composição da Atmosfera Terrestre", iniciou-se com a discussão sobre o ar atmosférico e do que ele é composto, sendo apresentados os diferentes gases que compõe esse material e a quantidade média de cada um deles. Para isso foi apresentada a Tabela 1 sendo discutidas as proporções dos gases nitrogênio, oxigênio e hidrogênio no ar atmosférico utilizando um cubo com marcações correspondentes aos volumes médios dos gases mais abundantes.

A partir dessa introdução foi apresentado o sistema conceitual "Forma de Apresentação da Matéria" (Fig. 5) e foi explicada a classificação do ar como material por este apresentar mais de uma substância. Foram citados exemplos de substâncias presentes no ar, dentre elas o gás oxigênio, o gás hidrogênio e o gás nitrogênio, utilizados nas explicações posteriores. 
Os estudantes foram questionados sobre os constituintes dos gases, a partir da questão: "Mas do que os gases presente no ar são feitos?". Após ouvi-los, foi explicado que um dos cientistas que tentou responder a essa pergunta foi Dalton. $O$ modelo proposto por Dalton foi apresentado aos alunos e, após essa explicação, eles representaram, pensando no modelo proposto, os gases nitrogênio, oxigênio e hidrogênio, utilizando massinha de modelar. Os modelos obtidos foram discutidos.

Tabela 1 - Composição do ar limpo e seco (Homosfera)

\begin{tabular}{|l|c|}
\hline \multicolumn{1}{|c|}{ COMPOSIÇÃO DO AR LIMPO E SECO (HOMOSFERA) } \\
\hline Componente & $\begin{array}{c}\text { Teor } \\
\text { (por metro cúbico) }\end{array}$ \\
\hline nitrogênio $\left(\mathrm{N}_{2}\right)$ & 780,8 litros \\
\hline oxigênio $\left(\mathrm{O}_{2}\right)$ & 209,5 litros \\
\hline argônio $(\mathrm{Ar})$ & 9,3 litros \\
\hline gás carbônico $\left(\mathrm{CO}_{2}\right)$ & $\approx 375$ mililitros \\
\hline neônio $(\mathrm{Ne})$ & 18 mililitros \\
\hline hélio $(\mathrm{He})$ & 5,2 mililitros \\
\hline metano $(\mathrm{CH} 4)$ & 1,8 mililitros \\
\hline criptônio $(\mathrm{Kr})$ & 1,1 mililitros \\
\hline hidrogênio $\left(\mathrm{H}_{2}\right)$ & 0,53 mililitro \\
\hline xenônio $(\mathrm{Xe})$ & 0,086 mililitro \\
\hline \multicolumn{1}{|c|}{ Fonte: Tolentino, Rocha-Filho, Silva (2004), p. 16} \\
\hline
\end{tabular}

No segundo momento foi realizada uma breve contextualização histórica, explicando que o cientista Gay-Lussac após realizar alguns experimentos envolvendo gases observou que o modelo de Dalton não era adequado para explica-los, e assim, cientistas buscaram elaborar um modelo que pudesse ser utilizado para explicar tais fenômenos (CHAIB, 1988). Foi discutida a proposta de Avogadro, que trouxe contribuições para o modelo atômico de Dalton, introduzindo o conceito de moléculas, considerando os gases como sendo formados por moléculas diatômicas - formados por dois átomos. Essas ideias foram dialogadas utilizando o sistema conceitual "Natureza da Matéria" (Fig. 6). 
Com a introdução do conceito de molécula, os estudantes representaram novamente os constituintes dos gases só que utilizando as contribuições de Avogadro ao modelo anteriormente apresentado, chamado neste trabalho de modelo de Dalton modificado, sendo cada um deles representados como moléculas diatômicas. Foram discutidas as representações com os estudantes.

Por fim, eles responderam a um questionário final buscando analisar as possíveis contribuições da aula.

\subsubsection{SEGUNDO ENCONTRO}

No segundo encontro foram retomadas as ideias abordadas na aula anterior e foi realizado um experimento demonstrativo-investigativo com uma garrafa PET (600 $\mathrm{mL}$ ), uma bexiga e um secador de cabelo. Para a realização desse experimento, a bexiga foi colocada no gargalo da garrafa e, utilizando o secador de cabelo, o ar dentro da garrafa foi aquecido por alguns minutos. Com isso, os estudantes puderam observar (nível macroscópico) que depois de algum tempo a bexiga encheu.

Para explicar o fenômeno, os alunos foram instigados a utilizar o sistema conceitual da Figura 12, procurando estabelecer relações lógicas entre os conceitos de matéria, material, substância e constituintes das substâncias. Além disso, para o nível submicroscópico, os estudantes fizeram desenhos para representar a distribuição dos constituintes das substâncias - das moléculas dos gases presentes no ar segundo o modelo de Dalton modificado - antes e após a realização da atividade experimental.

O segundo experimento realizado consistiu na observação de uma seringa com uma das extremidades fechadas por um êmbolo e com sua ponta fechada com o dedo. O êmbolo era comprimido enquanto a outra ponta foi mantida fechada. Foi possível observar que só era possível pressionar o êmbolo até certo volume, após isso não conseguíamos comprimir mais, e após soltar o êmbolo, este voltava ao estado inicial. Novamente, foi solicitado que os estudantes utilizassem o sistema conceitual da Figura 12 para explicar o fenômeno observado. E, buscando favorecer a compreensão do nível submicroscópico, os estudantes representaram utilizando o modelo de Dalton modificado, por meio de desenhos, as moléculas do gás no estado inicial (sem a ação 
de nenhuma força externa), ao comprimir o êmbolo, e no estado final (quando o êmbolo volta ao estado inicial).

\subsubsection{TERCEIRO ENCONTRO}

No terceiro encontro, os estudantes assistiram a um vídeo que tratava da morte de muitos peixes em um rio devido à falta de gás oxigênio na água: "Baixa oxigenação pode causar mais mortes de peixes no Rio Piracicaba"15.

Tendo como objetivo observar se os estudantes estavam compreendendo a diferença entre os conceitos trabalhados no sistema conceitual (material, substância, constituintes e átomo), os estudantes foram questionados sobre a possibilidade de os peixes morrerem por falta de oxigênio mesmo estando dentro da água. As respostas foram discutidas coletivamente.

Após essa introdução, foi realizada a eletrólise da água como atividade experimental. Para explicar o fenômeno, os alunos utilizaram o sistema conceitual da Figura 12. Para o nível submicroscópico, eles construíram modelos, utilizando massinha de modelar, para representar os constituintes das substâncias envolvidas nessa reação química: moléculas de água, de gás oxigênio e de gás hidrogênio, e a partir das representações construídas, escreveram as expressões representacionais para o fenômeno observado.

\footnotetext{
${ }^{15}$ Baixa oxigenação pode causar mais mortes de peixes no Rio Piracicaba. 2014. Disponível em: < http://g1.globo.com/sp/piracicaba-regiao/noticia/2014/02/baixa-oxigenacao-pode-causar-mais-mortes-depeixes-no-rio-piracicaba.html >. Acesso em: 24/05/2015.
} 


\section{Resultados e Discussão}

A metodologia apresentada no tópico anterior teve como objetivo analisar a utilização de sistemas conceituais hierarquicamente organizados e atividades envolvendo modelos e modelagem no ensino visando facilitar a transição entre os três níveis do conhecimento químico. Para isso, foram analisados os áudios das aulas, as fotos dos modelos construídos pelos estudantes e os questionários prévios e pós realização dos encontros.

Os resultados obtidos serão apresentados e discutidos nessa seção, seguindo a ordem em que foram trabalhados nos encontros, começando pela análise da apropriação dos conceitos de nível macroscópicos apresentados nas subseções 5.1 (a composição da atmosfera terrestre) e 5.2 (o conceito de ar atmosférico); seguidos dos conceitos de nível submicroscópicos e representacionais nas subseções 5.3 (as substâncias e seus constituintes) e 5.4 (natureza dos constituintes); e, por fim, do nível representacional na subseção 5.5 (elaborando a expressão representacional de uma reação química), na qual foram analisados os modelos construídos e as expressões representacionais elaboradas a partir destes.

\subsection{A COMPOSIÇÃO DA ATMOSFERA TERRESTRE}

Antes do início das atividades, os estudantes responderam ao questionário inicial 1: A composição da atmosfera terrestre. Esse questionário foi aplicado tendo como objetivo conhecer e analisar as concepções prévias dos estudantes, sendo composto por três perguntas:

1. Para você, o que é atmosfera?

2. Para você, o que é o ar?

3. Do que é constituído o gás nitrogênio, o gás oxigênio e o gás hidrogênio?

Esse questionário foi repetido após a aplicação da metodologia proposta para o primeiro encontro, sendo chamado de questionário final 1: A composição da atmosfera terrestre. Nele foram retiradas das questões a expressão "para você" que no questionário inicial foi utilizada para mostrar aos estudantes que estávamos 
buscando conhecer suas próprias concepções a respeito das perguntas, enquanto no questionário final buscava-se uma maior ênfase nos conceitos científicos elaborados após as atividades.

Como um dos objetivos da presente pesquisa é analisar se a utilização de sistemas conceituais, apresentados nas Fig. 5 e 6, podem facilitar na transição entre os três níveis do conhecimento químico, foram analisadas as respostas apresentadas pelos estudantes, verificando se estas atendiam as características dos conceitos científicos - sendo integrantes de um sistema hierárquico de inter-relações e tendo relações lógicas estabelecidas com outros conceitos (TOLENTINO et al., 1986). Essa análise foi realizada para os questionários inicial e final afim de verificar se, após a realização das atividades, houve um aumento na utilização de conceitos científicos.

Participaram do primeiro encontro 27 estudantes, porém um deles não esteve presente durante todas as atividades e não respondeu ao questionário final, por isso só foram considerados 26 questionários para a presente análise. As respostas para as questões foram classificadas em quatro categorias:

(1) não responderam;

(2) responderam utilizando conceitos cotidianos;

(3) responderam utilizando conceitos científicos parcialmente corretos; e

(4) responderam utilizando conceitos científicos de forma adequada.

É importante destacar que uma mesma resposta pode se enquadrar em duas categorias distintas, pois mesmo que o estudante desenvolva conceitos científicos, em muitas áreas seu pensamento continua a operar por conceitos cotidianos. Dessa forma, podem aparecer conceitos cotidianos e científicos em uma mesma expressão (VYGOTSKY, 2001).

A primeira pergunta do questionário se referiu a atmosfera terrestre, tema da aula em questão. Ao analisar as concepções prévias dos estudantes sobre esse conceito presente no questionário inicial 1, foi observado que a maioria (cerca de $58 \%$ das respostas) utilizava somente conceitos cotidianos. Abaixo temos alguns exemplos de respostas, classificadas como conceitos cotidianos, apresentadas pelos estudantes antes do desenvolvimento da atividade: 
Poucos estudantes (aproximadamente 19\%) elaboraram respostas com a presença de conceitos científicos, alguns utilizados de forma adequadas e outros não. Nas seguintes respostas percebemos que alguns estudantes, antes mesmo de iniciarmos nossa proposta, utilizaram-se de conceitos científicos - porém, de forma equivocada - para explicar o significado de atmosfera:

"É a camada da Terra que contém todos os gases que existem aqui" (A10)

"Atmosfera e tudo aquilo que e composto pelo ar ceu seja oxigênio nitrogênio e toda a poluição etc. (sic)" (A25)

Diferentemente das respostas que foram classificadas como conceitos cotidianos, os estudantes A10 e A25 explicam o conceito de atmosfera pensando em sua composição.

Alguns poucos estudantes responderam utilizando conceitos científicos de forma adequada, tais como:

"É uma camada gasosa que cobre a terra." (A19)

"Atmosfera é uma camada de gases que envolve a Terra." (A26)

O conceito de atmosfera foi discutido no início do primeiro encontro e após a aplicação da proposta, ao analisarmos os questionários finais, percebemos que o número de respostas que apresentavam conceitos científicos aumentou consideravelmente. Isso pode ser observado no gráfico presente na Figura 13.

Para entendermos como chegamos a esses resultados é necessário analisar como o conceito de atmosfera terrestre foi discutido no desenvolvimento da proposta.

Por ser o tema do projeto, o conceito de atmosfera terrestre foi discutido já no início do primeiro encontro com a pesquisadora perguntando qual o significado de atmosfera terrestre. Muitos estudantes responderam utilizando conceitos cotidianos e, a partir das respostas deles e das atividades demonstrativo-investigativas que se seguiram, foram introduzidos conceitos científicos sobre esse tema, como pode ser observada no trecho apresentado abaixo:

Pesquisadora: (...) Quem aí sabe o que é atmosfera terrestre?

Aluno: É uma camada acima da Terra, sei lá.

Aluno: Que fica por cima da Terra.

Pesquisadora: Mas do quê que é composta essa camada?

Vários alunos: De gases. 
Figura 13 - Classificação das respostas para o significado de atmosfera terrestre



Observa-se nesse trecho que a partir do conceito cotidiano apresentado pelos estudantes que afirmam que atmosfera é uma camada que fica por cima da terra, a pesquisadora busca introduzir um conceito científico, indagando sobre a composição da atmosfera terrestre. Nesse diálogo, ela busca apresentar os conceitos dentro do sistema conceitual explicando que a atmosfera terrestre é uma camada da Terra que é formada por diversas substâncias.

Conforme mencionado anteriormente e observado no gráfico da Figura 13, após as atividades propostas no primeiro encontro, ao analisarmos o questionário final 1, houve um aumento no número de respostas em que apareceram conceitos científicos $(76 \%)$ e uma diminuição no número de respostas que apresentavam somente conceitos cotidianos (19\%). Apesar disso, em aproximadamente metade das respostas que utilizaram conceitos científicos, estes estavam parcialmente corretos.

As respostas que mais apareceram com os conceitos científicos sendo utilizados de forma parcialmente correta são semelhantes as apresentadas abaixo:

"é a camada da Terra onde se encontra os gases." (A8)

"é a camada da terra em que e formada por gás nitrogênio, gás oxigênio, gás hidrogênio (sic)" (A21) 
$\mathrm{Na}$ primeira resposta, o aluno não descreve atmosfera terrestre como sendo formada por gases, mas sim o espaço onde os gases são encontrados, o que foi considerado um equívoco conceitual. Porém, quando esta é comparada a sua resposta inicial: "é como se fosse todo o planeta, conjunto de fauna e flora, mares e oceanos, e nós humanos", percebe-se que o estudante conheceu um novo significado - mais próximo de um conceito científico - para a atmosfera terrestre.

Para a segunda resposta, observa-se que o estudante destaca três (gás nitrogênio, oxigênio e hidrogênio) dentre vários outros gases como sendo os únicos que compõe a atmosfera terrestre. Esse deslize conceitual possivelmente se deu pela ênfase dada na representação desses três gases em outras atividades que ocorreram nesse encontro. Estas serão explicadas nos próximos tópicos.

\subsection{O CONCEITO DE AR ATMOSFÉRICO}

Pensando no sistema conceitual "formas de apresentação da matéria" (Fig. 5) inicialmente foi apresentado o conceito de atmosfera terrestre - camada de ar que envolve a Terra - e a partir desse significado foi introduzido o conceito de ar, conforme observa-se no trecho a seguir:

Pesquisadora: (...) Então, assim, a gente chama de atmosfera terrestre a camada de ar que envolve a Terra. (...) Mas então, você comentou comigo que eram gases, aí eu falei assim, que é a camada de ar, então do que é constituído esse ar?

Aluno: Ué, de substâncias, de gases.

Pesquisadora: Muito bem, então o ar é constituído de gases. Mas vocês sabem em quais proporções estão esses gases na atmosfera?

Após essa explanação, utilizando o cubo com as marcações correspondentes as proporções dos diferentes gases presentes no ar atmosférico, a pesquisadora discutiu a primeira parte do sistema conceitual (Fig. 5). Para uma melhor visualização desses sistemas, ambos foram impressos em um cartaz e colados na parede da sala (Fig. 14). 
Figura 14 - Cartaz com os sistemas conceituais que foram colados na sala de aula

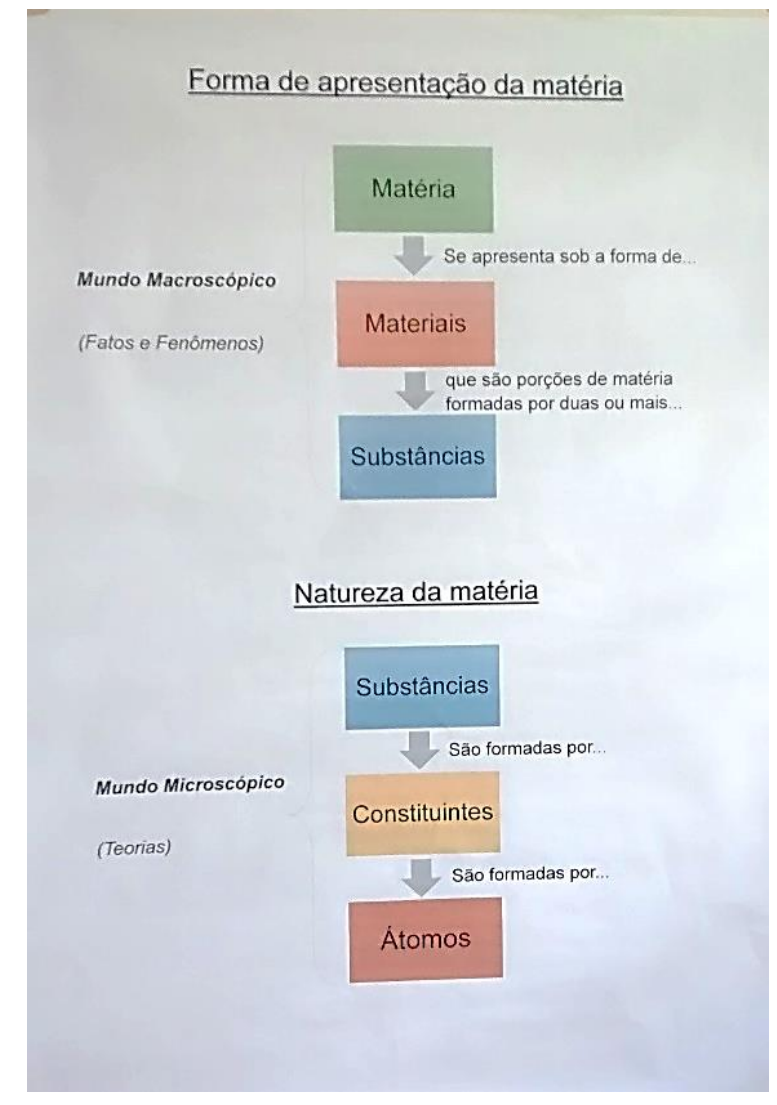

O trecho que se segue ilustra a introdução da classificação do ar como material e das substâncias que o compõe, desenvolvido pela pesquisadora após a discussão sobre o conceito de atmosfera terrestre:

Pesquisadora: Ou seja, como nós classificamos o ar na Química? O ar na Química é classificado como um material, o ar atmosférico é um material. Na Química a gente chama de material o que tem mais de uma substância.

Dá uma olhada aqui atrás ó. A gente tem aqui que a matéria se apresenta na natureza sob a forma de materiais, assim, o ar é um material, vocês conseguem me citar uma substância presente no material ar?

Aluno: Oxigênio

Aluno: Hidrogênio

Pesquisadora: Então todas essas são substâncias. Então agora a gente consegue classificar o ar, que é chamado de material porque ele tem mais de uma substância. E aqui a gente tem várias dessas substâncias.

Ao analisar as respostas obtidas para a segunda pergunta dos questionários inicial e final na qual foi perguntado o que é o ar, percebemos que após as atividades 
desenvolvidas, os estudantes também passaram a utilizar mais conceitos científicos, conforme pode ser observado na Figura 15 apresentada abaixo:

Figura 15 - Classificação das respostas apresentadas nos questionários inicial e final para o conceito de ar

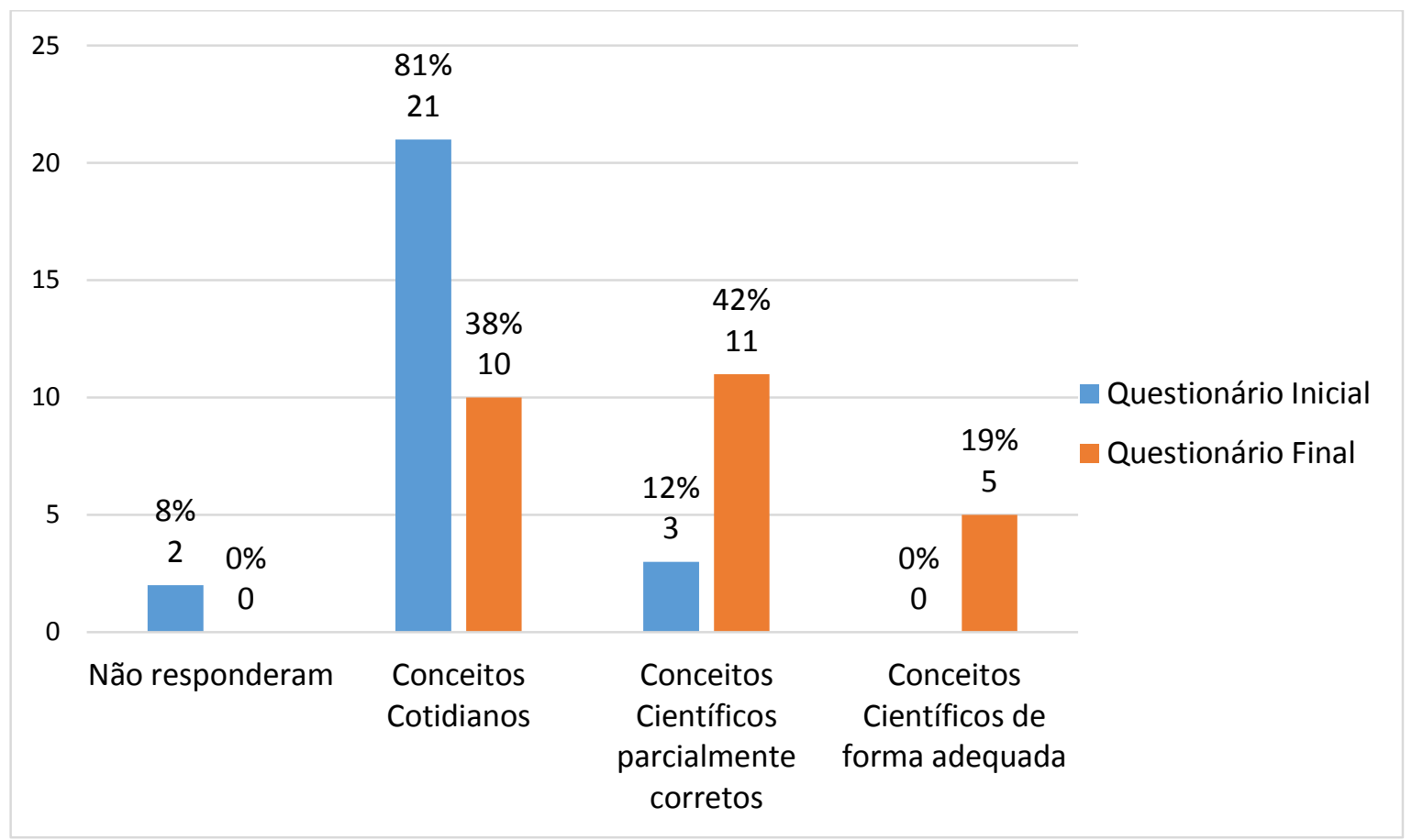

A partir da Figura 15, percebe-se que o número de respostas em que os estudantes utilizam apenas conceitos cotidianos no questionário inicial é bastante elevado, correspondendo a cerca de $81 \%$ do total de respostas. Além disso, nenhum estudante respondeu ao questionário prévio qual o significado de ar utilizando conceitos científicos de forma adequada.

Essa dificuldade em formar um conceito sobre o ar é relatada em outros trabalhos, como o de Stavy (1988) na qual a autora sugere que a invisibilidade do ar e dos gases em geral impede que crianças conceituem esses materiais espontaneamente, e o de Séré (1986) em que pesquisou-se como crianças, entre 11 e 13 anos de idade, entendiam o ar antes de estudarem o tema gases na escola e a autora concluiu que os estudantes estão preocupados com a sua utilização e função em objetos: encher pneu, pneu estourar, etc.

Ao analisarmos as concepções prévias dos estudantes entendidas como conceitos cotidianos, percebe-se que os dados obtidos corroboram com os resultados apresentados por Séré (1986) pois em muitas respostas o significado de ar é 
relacionado a sua função. Porém percebemos que apareceram respostas em que a ênfase não foi na função do ar mais em outros aspectos, por isso estes dados foram separados em quatro categorias, de acordo com a ideia central apresentada na resposta, são elas:

- Função: O ar é associado à sua função no cotidiano do estudante. A resposta que mais apareceu relaciona o ar à respiração:

"é um meio que a gente respira" (A23)

"Ar é o gás que nós respiramos" (A6)

- Efeitos ambientais: Os estudantes conceituaram o ar relacionando-o aos efeitos por ele exercidos no ambiente. A maioria dos estudantes que enfatizaram os efeitos ambientais, responderam que o ar é o vento. Outra resposta que apareceu em número considerável, entende o ar como sendo uma força:

“O vento (...)” (A9)

"O ar é uma força que existe na terra (...)" (A4)

- Natureza: O ar é entendido como sendo um de seus componentes. As respostas que mais apareceram afirmavam que o ar é o oxigênio:

"Ar é um oxigênio" (A3)

- Composição: Os estudantes relacionam o ar à sua composição sendo este entendido como uma mistura de gases. As respostas classificadas nesse grupo se assemelham aos exemplos que se seguem:

"É a mistura de gases (...)" (A10)

"É uma coisa (...) compostas por muitas substâncias" (A20)

O percentual de respostas relativo a cada umas das quatro categorias acima é apresentado na Figura 16 a seguir.

Mais de $50 \%$ das respostas classificadas como conceitos cotidianos se referem à função, e a maioria destas destacam o ar e sua função fisiológica - como sendo algo que respiramos, enquanto os $50 \%$ restantes praticamente dividem as outras três categorias. 
Figura 16 - Percentual de respostas classificadas como conceito cotidiano para o conceito de ar de acordo com a ideia central do estudante

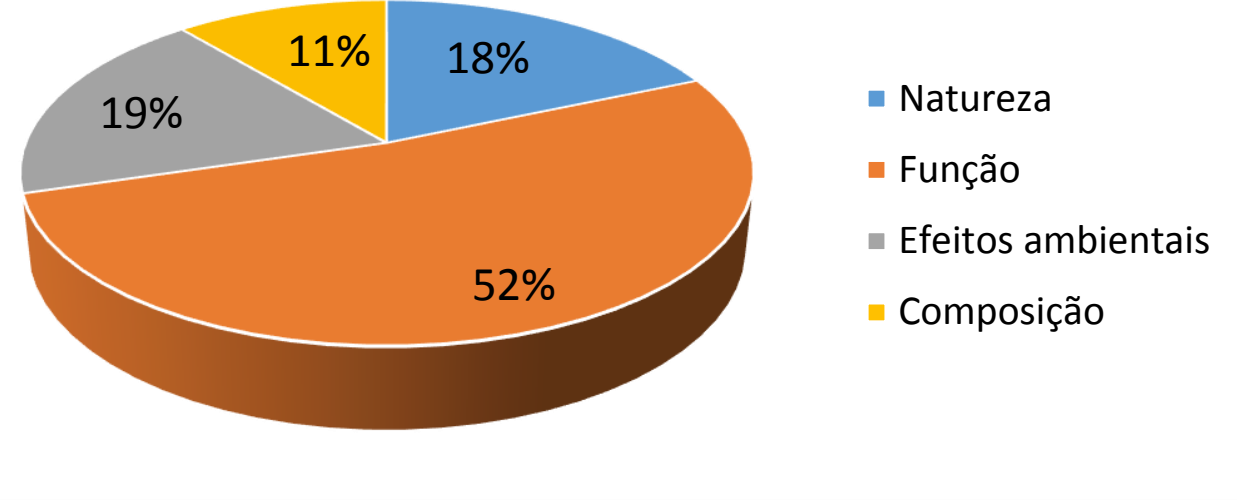

Após a realização das atividades que aconteceram no primeiro encontro, observa-se uma diminuição no número de respostas classificadas como conceitos cotidianos (39\%) e um aumento significativo nas respostas com conceitos científicos parcialmente (42\%) e totalmente corretos (19\%) no questionário final, conforme pode ser observado na Figura 15.

Essa maior utilização de conceitos científicos pode ser atribuída a apresentação do conceito de ar dentro do sistema conceitual "forma de apresentação da matéria" (Fig. 14) realizada pela pesquisadora. A partir da discussão da composição do ar atmosférico, utilizando um cubo com marcações correspondentes ao teor dos diferentes gases presentes no ar, foi explicado que o ar é um material por ter mais de uma substância. Com essa, e outras atividades que serão descritas posteriormente, no questionário final foram obtidas respostas com conceitos científicos utilizados de forma correta, é o caso da resposta que aparece na transcrição abaixo:

"o ar é um material formado por mais de uma substância." (A13)

Dentre os conceitos parcialmente corretos, as respostas que mais apareceram são bem próximas aos exemplos abaixo em que o estudante descreve o ar como matéria e omite a categoria subordinada, que é a de material:

"Ar é uma matéria constituído de várias substâncias diferentes" (A5) "É uma matéria, que é formada por várias substâncias" (A12) 
Após essas atividades, a próxima etapa consistiu em uma discussão em nível submicroscópico em que buscou-se explicar o conceito de substâncias e sua constituição. Para isso, continuaram sendo utilizados os sistemas conceitual e foram desenvolvidas atividades com modelos e modelagem, estas são explicadas no tópico que se segue.

\subsection{As substâncias e seus constituintes}

No terceiro momento, iniciou-se a discussão sobre o que forma as substâncias presentes no ar. Já havia sido discutido o conceito de ar utilizando o sistema conceitual "forma de apresentação da matéria" (Fig. 14) e, nessa etapa foi abordado como a Ciência explica a constituição das substâncias presentes no ar, também remetendo ao sistema conceitual. Para isso, após falar sobre algumas das substâncias presentes no ar, como o gás hidrogênio, o gás oxigênio e o gás nitrogênio, foi perguntado aos alunos do que são constituídas essas substâncias. A transcrição abaixo ilustra esse diálogo:

Pesquisadora: A gente já sabe que o ar é formado por várias substâncias, mas e essas substâncias, cada um desses gases, é formado pelo quê?

Aluno: Moléculas

Aluno: Por átomos

A partir daí foi explicado aos estudantes as ideias de Dalton, ressaltando que ele fora um dos cientistas que tentou explicar essa questão:

Pesquisadora: Uma das pessoas que tentou responder a essa pergunta foi Dalton. Esse cientista se questionou do que seriam constituídos os gases, essas substâncias. E Dalton disse que essas substâncias seriam constituídas de átomos, que seriam as menores partículas da matéria, seriam partículas esféricas, indivisíveis. O que diferenciaria um átomo do outro seria a massa.

Pensando nas ideias de Dalton, foi pedido aos estudantes que representassem usando massinhas de modelar os átomos que constituiriam as substâncias gás oxigênio, gás hidrogênio e gás nitrogênio. Definimos que seria utilizada a massinha 
de cor azul para representar o oxigênio, a amarela para o nitrogênio e a rosa para o hidrogênio.

No primeiro momento, houve certa resistência por parte dos estudantes que diziam não saber o que fazer quando entregamos as massinhas. Foi explicado mais uma vez quais eram as ideias de Dalton sobre os constituintes das substâncias e durante a atividade percebe-se que faltou uma maior discussão sobre o que são modelos, sua importância e como eles são utilizados na Química. Justi (2006) defende essa ideia, entendendo que a discussão de modelos e modelagem em aulas de Química atende a um dos propósitos para se ensinar Ciências: o de aprender sobre Ciências, pois a partir dela é possível que os estudantes compreendam aspectos relacionados a natureza dos modelos e como estes são importantes para o desenvolvimento da pesquisas científicas e divulgação delas.

Apesar dessa dificuldade, a maioria dos modelos concretos produzidos pelos alunos se adequavam as propostas de Dalton: os estudantes construíram esferas de tamanhos semelhantes. É o caso da representação apresentada na Figura 17 a seguir:

Figura 17 - Modelo construído por um estudante representando os átomos de oxigênio, nitrogênio e hidrogênio, a partir das ideias de Dalton

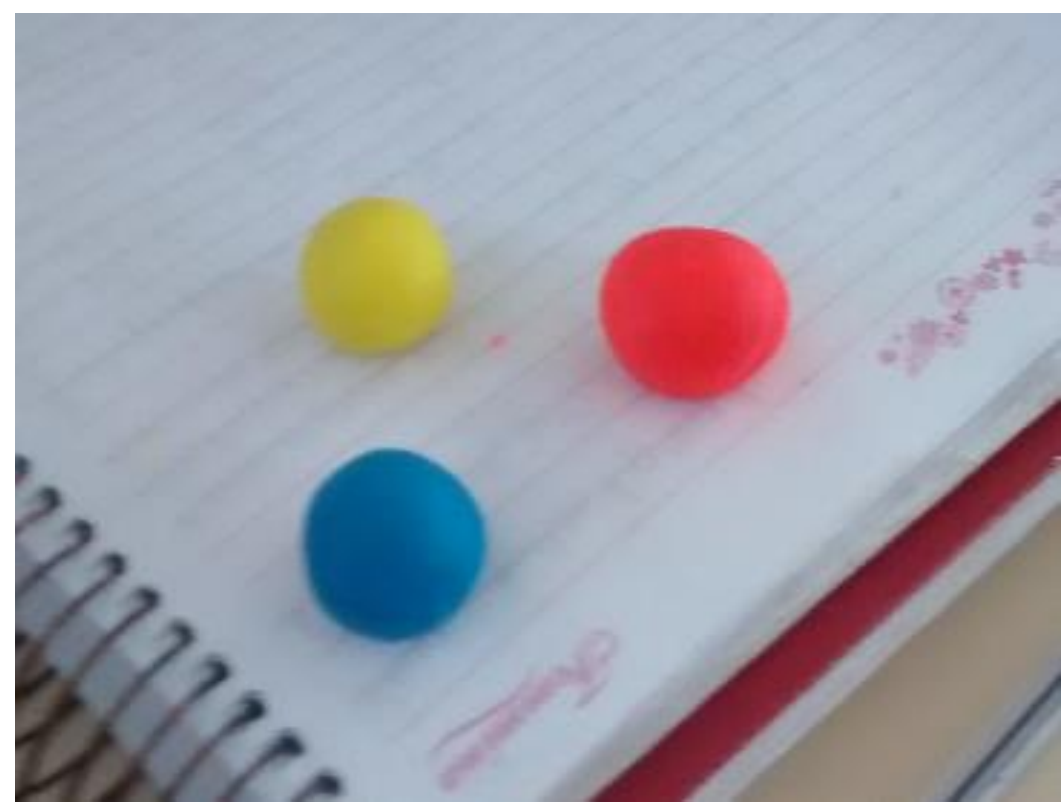

Fonte: do autor

Já outros modelos, apresentavam diferenças significativas das ideias de Dalton. Estes são apresentados na Figura 18 a seguir: 
Figura 18 - Modelos construídos por diferentes estudantes representando os átomos de oxigênio, nitrogênio e hidrogênio, que não se adequaram as ideias de Dalton
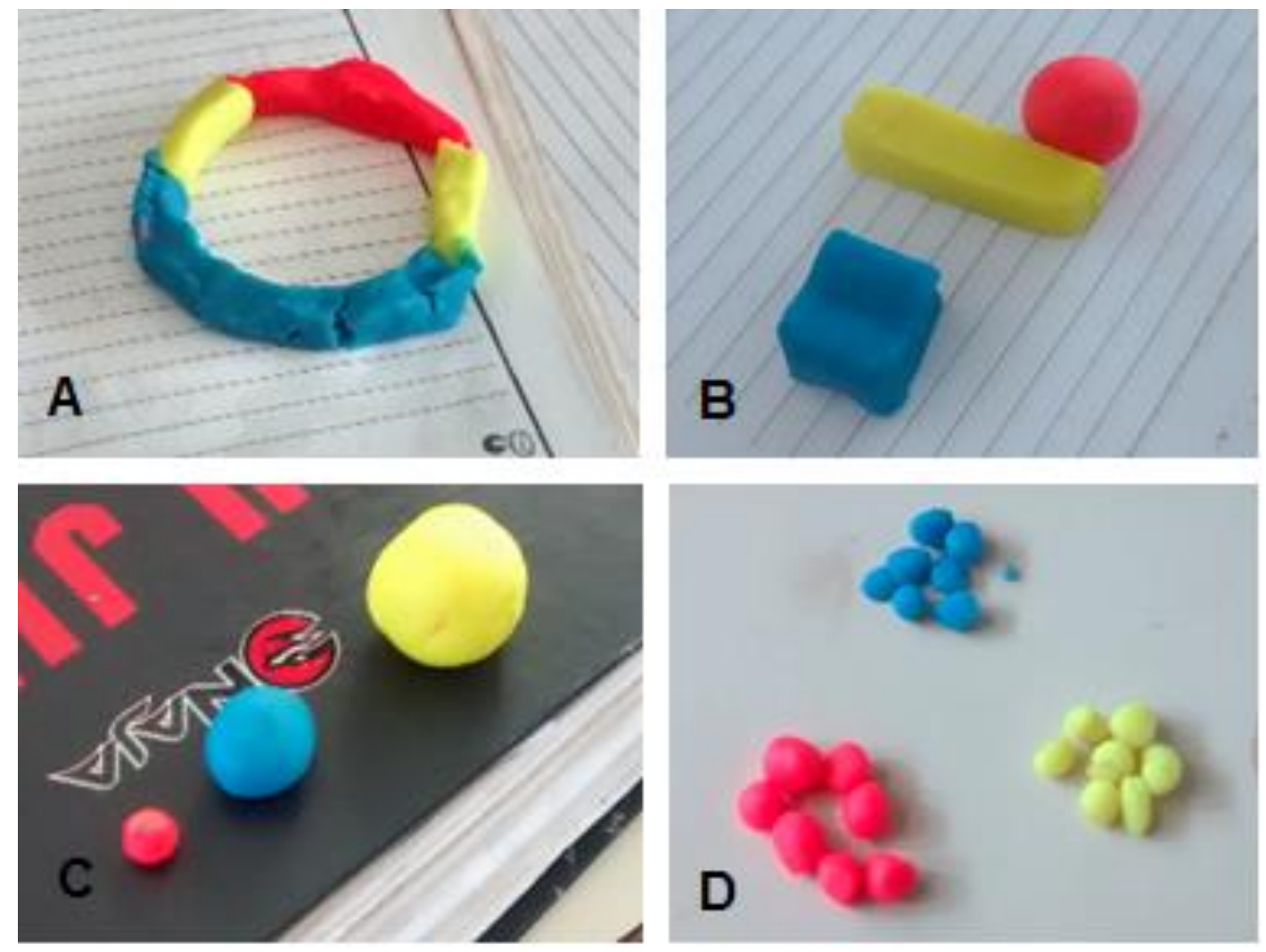

Fonte: do autor

Ao deparar com essas representações, foi questionado a cada estudante quais ideias deles resultaram nos modelos propostos. Para o primeiro e segundo modelos (Fig. 18a e 18b), eles não souberam explicar, respectivamente, o porquê da construção do círculo com diferentes cores e o de utilizar diferentes formas geométricas na representação de cada um dos átomos. Fez-se necessário retomar mais uma vez as ideias de Dalton para que os estudantes entendessem que as representações construídas por eles não se adequavam as ideias que estávamos utilizando, como pode ser observado na transcrição a seguir:

Pesquisadora: Por que você representou as formas diferentes?

Aluno: Porque pra mim, eu acho que cada um tem uma forma diferente.

Pesquisadora: Mas o que Dalton falou?

Aluno: Que eram esferas indivisíveis.

Pesquisadora: Que eram esferas. Então a gente já tem um probleminha aí segundo o modelo de Dalton.

Para o terceiro modelo (Fig. 18c), quando questionado ao estudante o porquê de representar os átomos com tamanhos diferentes ele se referiu a Tabela 1 
apresentada no início da atividade na qual estavam descritos o teor, em litro por metro cúbico, dos gases da atmosfera terrestre. Ele explicou que representou o nitrogênio com uma esfera maior pois este seria o átomo de maior massa e chegou a essa conclusão ao observar a Tabela 1 que mostrava a composição do ar limpo e seco. Ou seja, esse estudante confundiu massa com teor dos gases presentes na atmosfera e associou essa medida ao tamanho do átomo.

O quarto modelo (Fig. 18d) foi explicado pelo estudante como pode ser observado na transcrição:

Aluno: Cada bolinha é um átomo e cada quantidade de átomo é uma molécula.

Isto é, o estudante entende o conceito de molécula como sendo um aglomerado de átomos. Nas atividades realizadas, não havia sido discutido o significado de molécula, sendo esta uma concepção prévia do estudante.

Para se evitar o surgimento de concepções equivocadas como a deste estudante é que sugerimos que os conceitos ensinados em Química sejam discutidos utilizando sistemas hierarquicamente organizados. Segundo Vogelezand (1987), essas dificuldades também podem ser atribuídas ao fato de conceitos como os de átomos, moléculas, serem discutidos muito precocemente, antes mesmo de ser trabalhado o conceito de substância. Para ele, o conceito de substância está muito mais próximo ao cotidiano dos estudantes e deveria ser introduzido previamente:

Esta descrição da molécula, naturalmente, requer um conceito de
substância que tenha sido introduzido anteriormente, pois os alunos
não seriam capazes de compreender o que se entende por 'molécula'
se eles não sabiam o que se entende por 'substância'.
(VOGELEZAND, 1987, p. 520, tradução nossa)

Mesmo que a abordagem realizada em nossa proposta discuta o conceito de substância antes de dirigir a atenção aos constituintes delas, os estudantes tiveram acesso a essas informações já no ensino fundamental, sendo o conceito de átomo um dos primeiros a ser discutido no ensino de Química. Nesse contexto, Kind (2004) destaca a importância de se possibilitar que os estudantes aprendam os significados técnicos, a linguagem química, pois muitas vezes são utilizados os mesmos termos no cotidiano com um significado diferente deles no contexto científico, sendo o caso do termo substância.

Após a construção dos modelos, passamos para a próxima etapa da atividade, que consistiu no teste do modelo de Dalton. Nesse momento, a pesquisadora explicou 
um dos problemas vivenciados pelos cientistas em relação aos volumes obtidos a partir de reações envolvendo gases e que resultaram em uma modificação no modelo proposto por Dalton.

Para isso, foi utilizada a reação entre o gás oxigênio e o gás nitrogênio formando o monóxido de nitrogênio. Foi pedido que os estudantes representassem essa reação utilizando os modelos que haviam construído.

A pesquisadora explicou que segundo o modelo de Dalton modificado esperava-se que ao reagir um volume de gás oxigênio com um volume de gás nitrogênio seria obtido um volume de monóxido de nitrogênio. A transcrição a seguir relata o diálogo dela com os estudantes, explicando os resultados que foram obtidos pelos cientistas:

Pesquisadora: Era um volume para um volume formando um volume... E o que foi percebido experimentalmente?

Gay-Lussac percebeu que, experimentalmente, quando reagia um volume de gás nitrogênio com um volume de gás oxigênio formava dois volumes de monóxido de nitrogênio.

Até esse momento, as substâncias gás oxigênio e gás nitrogênio estavam sendo entendidas como formadas por átomos de oxigênio e nitrogênio, respectivamente, e desta forma, ao entender o monóxido de nitrogênio como a união entre um átomo de oxigênio com um átomo de nitrogênio, Gay-Lussac não conseguiu explicar o fato de serem formados dois volumes de óxido de nitrogênio.

Foi pedido que os estudantes representassem duas vezes cada monóxido de nitrogênio, ao invés de um só como eles tinham representado no início dessa etapa, e olhando para os modelos foi questionado se eles tinham ideia do porquê desse problema ou sabiam como solucioná-lo. O diálogo transcrito abaixo ilustra a resposta de três alunos diferentes e da pesquisadora sobre essa questão:

Aluno: O experimento dele deu errado.

Pesquisadora: O experimento dele dar errado é uma hipótese. Mas supondo que ele testou esse experimento uma, duas, três vezes, e outras pessoas repetiram esse experimento e ai ao invés de encontrar um volume, ele encontrou dois volumes (...)

E agora, como resolver esse problema a partir do que você tem aqui?

Aluno: Não tenho nem ideia.

Aluno: Tem dois átomos de cada um.

A partir desse diálogo percebe-se que a introdução da história da Ciência nessa atividade permitiu que alguns estudantes compreendessem aspectos relacionados a 
natureza da Ciência, entendendo-a como uma atividade humana, sujeita a erros e possível de ser modificada.

Conforme pode ser observado na transcrição acima, um dos estudantes sugeriu uma modificação que solucionava o problema encontrado pelos cientistas na época: a formação de dois volumes de óxido de nitrogênio poderia ser explicada tendo dois átomos de oxigênio e dois átomos de nitrogênio. Foi explicado aos estudantes que Avogadro foi o cientista que trouxe essa contribuição ao modelo de Dalton, entendendo que os gases poderiam ser formados por dois átomos, ou seja, moléculas diatômicas, como pode ser observado na transcrição a seguir. Esta proposta feita por Avogadro neste texto é denominada de modelo de Dalton modificado.

Pesquisadora: Então na verdade, pensando nesse problema, (...) Avogadro disse que os gases não eram constituídos de átomos mas sim de moléculas diatômicas. Ou seja, seriam dois átomos ligados. Então o gás oxigênio seriam dois átomos de oxigênio ligados, o gás nitrogênio seriam dois átomos de nitrogênio ligados.

Segundo o modelo de Dalton seria formado por apenas um átomo, com essa ideia de Avogadro, ele introduz o conceito de molécula. $\mathrm{Na}$ verdade, não seria formado por um átomo, seria formado por dois átomos e isso seria uma molécula.

Mesmo com esses avanços, muitos estudantes sentiram dificuldades na compreensão dessa etapa. $\mathrm{O}$ argumento utilizado por alguns se referia a utilização da ideia de volume de gás e, posteriormente, de átomo. Alguns estudantes questionaram se os cientistas chamavam os átomos de volume. A pesquisadora explicou que uma das propriedades que os cientistas utilizam para analisar uma reação química envolvendo gases é o volume, sendo essa uma forma de mensurar a quantidade de gás que se formou.

Para finalizar a atividade, foi pedido que representassem o gás oxigênio, o gás nitrogênio e o monóxido de nitrogênio, a partir das ideias de Dalton modificadas por Avogadro. Como já estava no final do primeiro encontro, alguns alunos ficaram mais dispersos e brincavam com as massinhas de modelar. Foi pedido que eles se concentrassem para que concluíssemos a atividade.

Alguns estudantes conseguiram construir com bastante facilidade os modelos propostos, e aos outros eram dadas orientações individuais que possibilitaram que todos modelassem as moléculas do gás oxigênio e gás nitrogênio. 
Por fim, os conceitos discutidos no primeiro encontro foram retomados utilizando o sistema conceitual Formas de Apresentação da Matéria e os estudantes responderam ao questionário final 1 , referente ao primeiro encontro.

Com a terceira pergunta: "Do que é constituído o gás nitrogênio, o gás oxigênio e o gás hidrogênio? ", presente nos questionários 1 , inicial e final, foi possível analisar se a atividade proposta favoreceu a compreensão dos estudantes sobre os constituintes das substâncias. Os dados obtidos nesses questionários são apresentados na Figura 19:

Figura 19 - Classificação das respostas apresentadas nos questionários inicial e final para a pergunta referente aos constituintes das substâncias

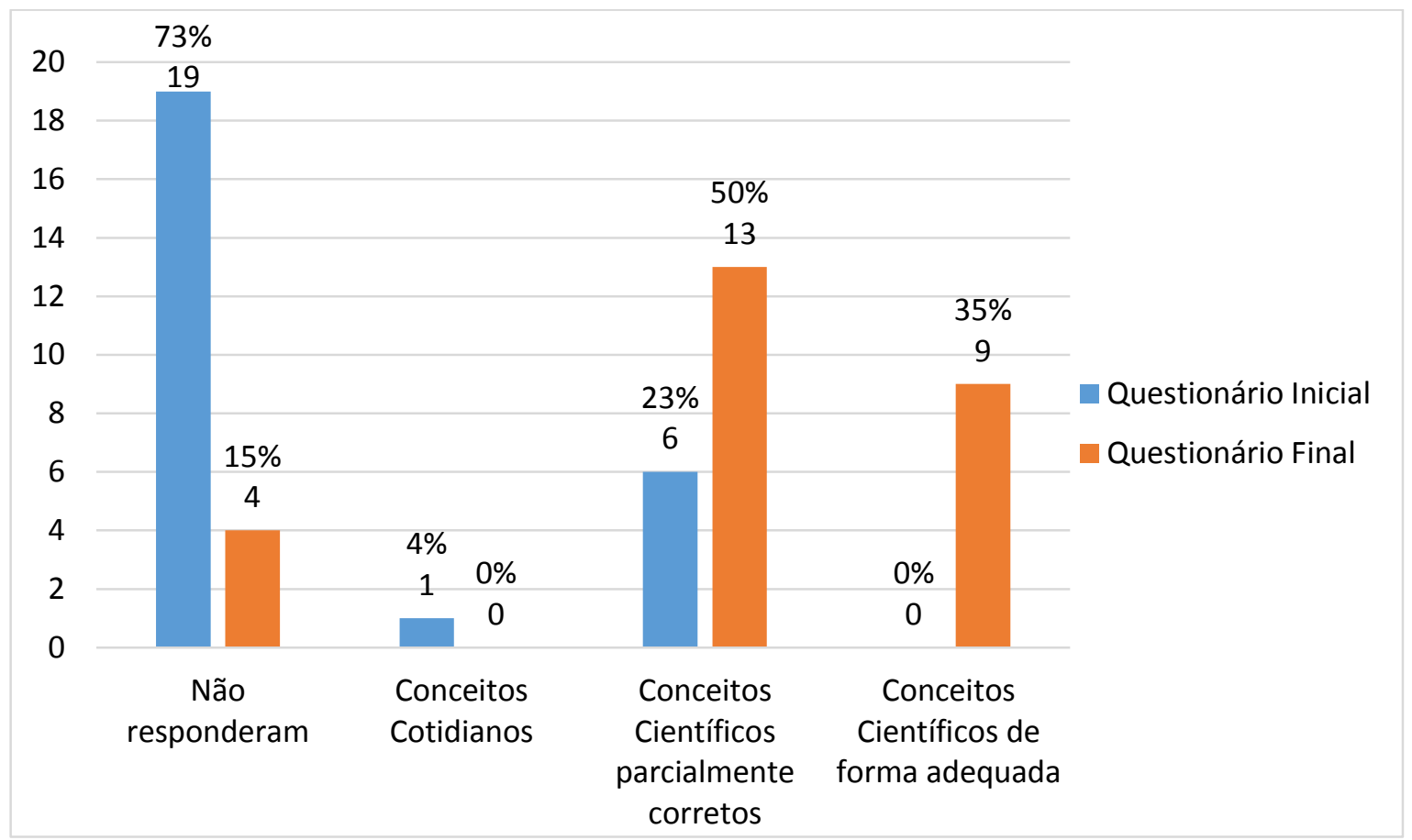

Ao analisarmos os dados apresentados na Figura 19, verifica-se que inicialmente a grande maioria dos estudantes (73\% do total) não responderam a questão e poucos (23\% do total) responderam utilizando conceitos científicos parcialmente corretos e nenhum conseguiu responder de forma totalmente correta. Após a realização das atividades, apenas 4 estudantes (15\%) não responderam à questão, 13 (50\%) responderam utilizando conceitos científicos parcialmente corretos e $9(35 \%)$ responderam utilizando conceitos científicos de forma adequada.

Deste modo, visando possibilitar uma melhor compreensão desses significados com o objetivo de atingir um maior percentual de estudantes que utilizem esses 
conceitos de forma adequada, no módulo didático sugere-se que em um primeiro encontro seja trabalhado o modelo de Dalton e em um segundo, o de Dalton modificado. Além disso, devido à dificuldade para o entendimento por parte dos estudantes das possíveis motivações que levaram as modificações do modelo de Dalton, sugerimos a utilização de simulações computacionais, vídeos, slides, animações que retratem os problemas observados pelos cientistas na época com relação aos volumes de gases obtidos em reações químicas e que resultaram nas modificações desse modelo. Um exemplo de simulação computacional que pode ser utilizada para esse fim é apresentado no módulo didático disponível no Apêndice $A$ desse trabalho.

\subsection{NATUREZA DOS CONSTITUINTES}

O segundo encontro ocorreu com 22 estudantes e foi iniciado retomando as discussões realizadas na aula anterior sobre o ar, seus gases e os constituintes desses gases, com suas respectivas classificações no sistema conceitual. Era perguntado aos estudantes se o ar é um material ou uma substância, exemplos de substâncias presentes no ar, pelo que são constituídas essas substâncias, etc.

Em seguida foi realizado um experimento demonstrativo-investigativo sendo este trabalhado segundo as ideias de Johnstone (1982, 2006, 2009) para abordagem dos três níveis de representação do conhecimento químico que optamos por denominar de aspectos macroscópicos, interpretação submicroscópica e expressões representacionais.

Assim, a atividade foi iniciada com a pergunta: "É possível encher um balão sem assoprar? ", realizada com o objetivo de promover um maior interesse, estimular a curiosidade, instigar os estudantes a refletirem sobre a questão proposta na busca por respostas e conhecer algumas de suas concepções prévias.

Após ouvi-los e serem discutidas algumas respostas, foi realizado 0 experimento utilizando um secador de cabelos, uma garrafa PET de $600 \mathrm{~mL}$ e uma bexiga. $O$ balão foi colocado no gargalo da garrafa e o ar dentro da garrafa foi aquecido com o secador de cabelo, e como aspectos macroscópicos, foi possível observar que o balão que inicialmente estava murcho, ficou mais cheio. 
Foi perguntado aos estudantes o que aconteceu no experimento e como a Química explica o fenômeno que observaram. Nessa etapa, eles foram incentivados a utilizar o sistema conceitual estudado procurando estabelecer relações lógicas entre os conceitos.

$\mathrm{Na}$ transcrição a seguir observa-se que os estudantes tentam explicar o macroscópico por meio de interpretações submicroscópicas, apesar da dificuldade de utilizar os conceitos dentro do sistema conceitual trabalhado:

Pesquisadora: Primeira coisa que eu quero perguntar, por que o balão enche?

Aluno: Eles se agitam.

Aluno: Os átomos ficam tipo mais agitados e o espaço entre eles aumentam.

Nesses trechos percebe-se que alguns estudantes ainda entendem o ar como sendo composto por átomos, não utilizando em suas respostas os conceitos de substâncias e constituintes (que para o caso em questão seriam moléculas).

Buscando possibilitar que os alunos compreendessem as inter-relações entre os conceitos, ao fazer a interpretação submicroscópica do experimento, foi explicado que quando o ar é aquecido ele expande, e essa dilatação é decorrente do aumento dos espaços vazios entre as moléculas presentes nas substâncias que compõe o ar. Desta forma, na explicação os conceitos de constituintes (no caso, moléculas), substâncias e material foram abordados conforme são apresentados no sistema conceitual.

Apesar disso, alguns questionamentos realizados pelos estudantes demonstram que a partir da atividade observada e da interpretação submicroscópica, houve certa confusão ao utilizar o conceito de constituintes das substâncias em seus raciocínios, conforme será relatado nos exemplos que se seguem.

Após discutirmos as interpretações submicroscópicas, foi solicitado que os estudantes desenhassem modelos que representassem os constituintes dos gases dentro da garrafa antes (inicial) e após o aquecimento (final).

Ao analisar as representações produzidas pelos estudantes foram avaliados os seguintes aspectos:

- Natureza dos constituintes dos gases - nesse aspecto foi avaliada a forma como os estudantes representaram os constituintes das substâncias: se eles 
utilizaram o modelo de Dalton modificado representando moléculas diatômicas, se representaram átomos ou não representaram nem átomos nem moléculas, utilizando outra forma de representação.

- Distribuição das entidades no espaço - foi observado como as entidades representadas pelos estudantes foram distribuídas no espaço, se estas estavam uniformemente separadas ou se foram representadas concentradas em diferentes partes do recipiente.

- Conservação do número de entidades antes e após o experimento - foi verificado se ao representarem as entidades das substâncias presentes no ar, os estudantes aplicam o princípio da conservação da matéria para o fenômeno observado, considerando que o número de entidades ao final do experimento como sendo igual ao inicial.

Ao analisar o primeiro aspecto, foi observado como os estudantes representavam os constituintes das substâncias para verificar se, após as discussões, eles entenderam os gases presentes no ar como sendo formados por moléculas diatômicas tanto antes como após o aquecimento. Desta forma, os desenhos que eles produziram foram observados analisando as diferentes formas de representação das entidades por eles apresentadas, sendo estas divididas em quatro categorias: moléculas diatômicas, átomos isolados, moléculas como aglomerado de átomos, e outras entidades. Os dados obtidos dessa análise são apresentados na Tabela 2:

Tabela 2 - Distribuição quanto à natureza dos diferentes modelos dos constituintes das substâncias para representar a expansão do ar desenhados pelos estudantes

\begin{tabular}{|c|c|c|c|c|}
\hline Natureza dos constituintes & \multicolumn{2}{|c|}{ Inicial } & \multicolumn{2}{c|}{ Final } \\
\hline & $\begin{array}{c}\text { Número } \\
\text { de alunos }\end{array}$ & $\begin{array}{c}\text { Percentual } \\
\text { de alunos }\end{array}$ & $\begin{array}{c}\text { Número } \\
\text { de alunos }\end{array}$ & $\begin{array}{c}\text { Percentual } \\
\text { de alunos }\end{array}$ \\
\hline $\begin{array}{c}\text { Moléculas diatômicas } \\
\text { Átomos isolados }\end{array}$ & 13 & $47 \%$ & 9 & $36 \%$ \\
\hline $\begin{array}{c}\text { Moléculas como aglomerado de átomos } \\
\text { (mais de dois átomos) }\end{array}$ & 6 & $21 \%$ & 8 & $32 \%$ \\
\hline Outras entidades & 6 & & & $20 \%$ \\
\hline
\end{tabular}


A partir da Tabela 2, percebe-se que ao representar os constituintes antes do aquecimento, em 13 modelos (47\%) foram desenhados constituintes das substâncias como moléculas diatômicas e, após o experimento com o aquecimento e expansão do ar, esse número cai para 9 modelos (36\%). Em contrapartida, inicialmente foram observados 6 modelos (21\%) em que apareciam os constituintes sendo representados como átomos isolados e, após, 8 modelos (32\%) representaram os constituintes como átomos isolados.

Essa diminuição no número de representações de moléculas diatômicas e aumento no número de representações com átomos isolados pode ser atribuída a dificuldade de entender o aumento dos espaços vazios como sendo decorrente do aumento dos espaços entre as moléculas, sendo entendido por alguns estudantes como aumento dos espaços entre os átomos, com a consequente separação e representação dos constituintes como átomos isolados. É o caso da representação das estudantes apresentadas na Figura 20 abaixo:

Figura 20 - Representação dos constituintes das substâncias antes, como moléculas diatômicas, e após, como átomos isolados, o aquecimento do ar

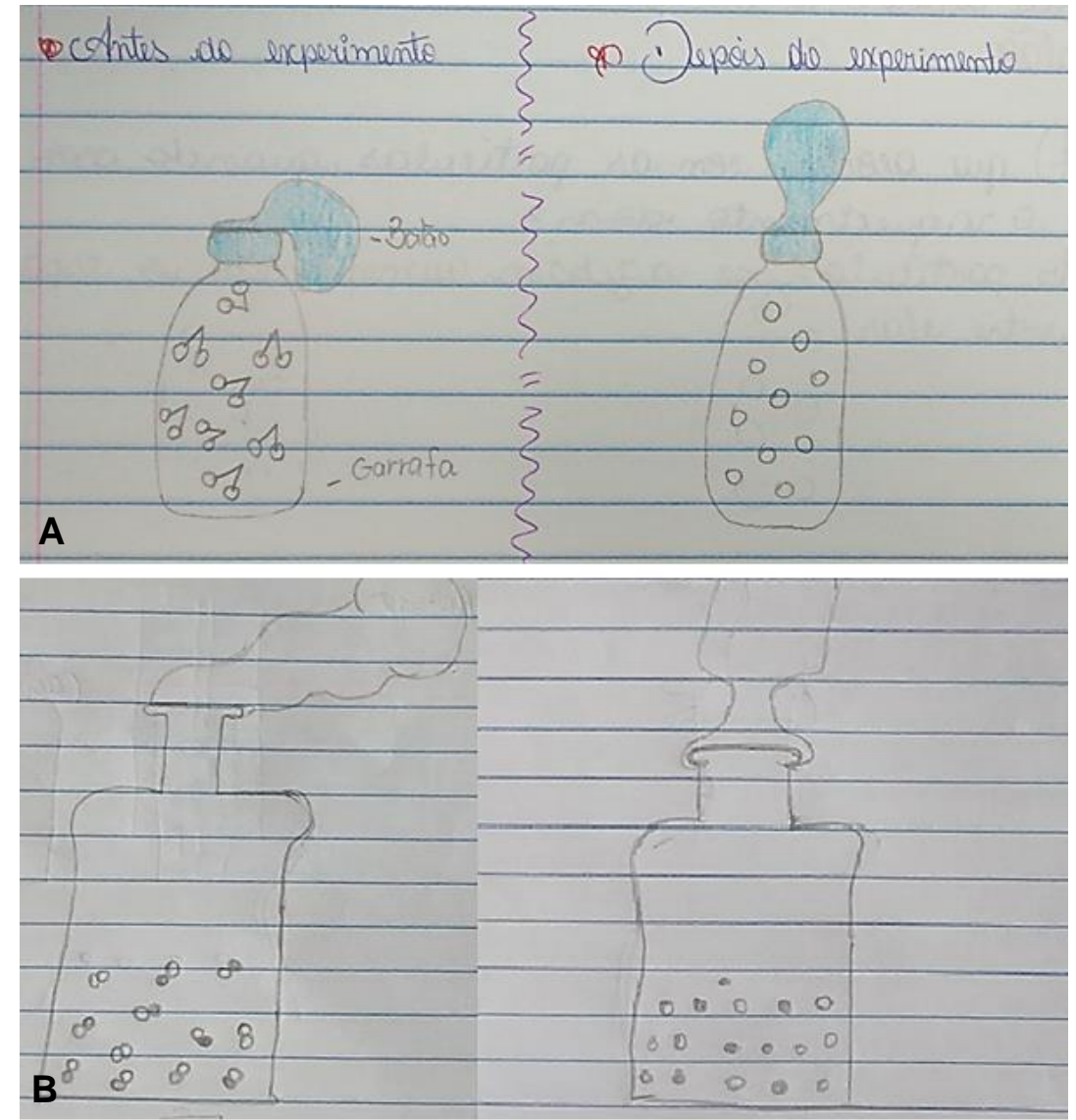

Fonte: do autor 
Com esses resultados percebe-se a importância de se discutir a natureza das substâncias utilizando os sistemas conceituais (Fig. 6), pois os alunos ao serem introduzidos ao estudo da Química a partir de conceitos apresentados fora de uma estrutura lógica definida, muitas vezes entendem os átomos (e não as moléculas, como é o caso dos gases estudados) como os constituintes das substâncias. Essa concepção errônea poderá resultar na dificuldade de compreender como ocorrem as reações químicas e o significado das equações utilizadas para representa-las, bem como as relações estequiométricas e o balanceamento de reações, entre outras.

A dificuldade na compreensão dos constituintes das substâncias também é observada nos 6 modelos (21\%) em que aparecem a representação das moléculas como aglomerado de átomos que é representada na Figura 21 abaixo:

Figura 21 - Representação dos constituintes das substâncias antes e após o aquecimento do ar por uma estudante no qual as moléculas são representadas como aglomerados de átomos

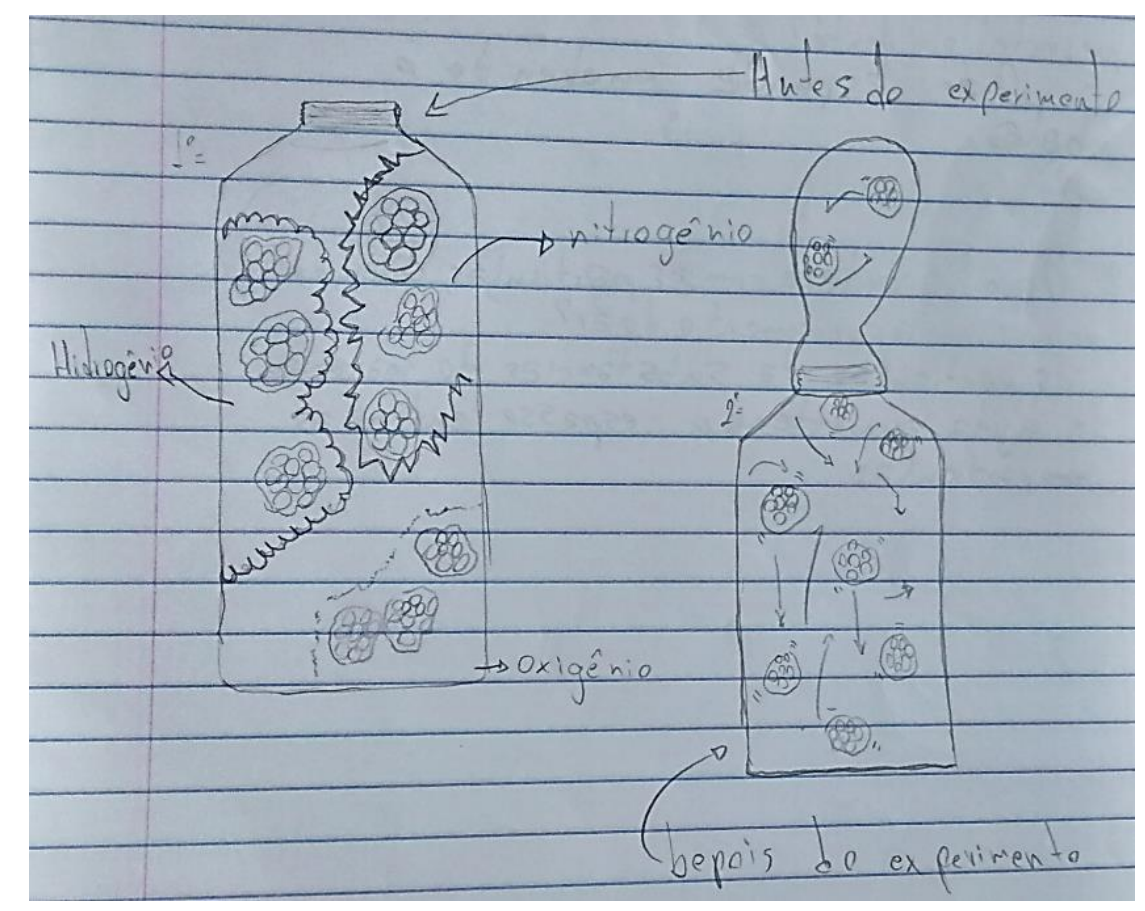

Fonte: do autor

$\mathrm{Na}$ representação apresentada na Figura 21, antes do aquecimento do ar com o secador de cabelo, o estudante representa os aglomerados de átomos em diferentes grupos separados de acordo com as substâncias, estando aparentemente estáticos. Já após o aquecimento, ele representa setas que indicam os aglomerados em movimento. A partir do desenho, pode-se inferir que este estudante não compreendeu 
os gases presentes no ar como sendo formados por moléculas diatômicas, conforme o modelo atômico de Dalton modificado e, além disso, entende que as entidades que formam cada uma das substâncias presentes no ar estão estáticas e agrupadas antes do fornecimento de energia ao sistema em questão. Desta forma, é importante desenvolver estratégias que possibilitem aos estudantes entenderem 0 comportamento dos constituintes das substâncias no estado gasoso.

Já alguns estudantes, ao representarem as entidades presentes nas substâncias dentro da garrafa, desconsideraram os modelos de Dalton, desenhando outras formas de representação. Na Figura 22 abaixo é representada uma dessas formas: o estudante representa as diferentes entidades com formas geométricas diferentes. É possível observar que apesar de não representar os átomos como esferas, como proposto por Dalton, no desenho à esquerda algumas entidades são apresentadas em pares e percebe-se que a aluna considerou a presença de estruturas formadas por dois átomos, enquanto no desenho à direita, todas as entidades são apresentadas de forma isolada. Desta forma, a aluna assumiu que com o aumento da temperatura ocorre um aumento dos espaços entre os átomos, fazendo com que eles se separem.

Figura 22 - Representação dos constituintes das substâncias antes e após o aquecimento do ar por uma estudante em que as entidades são representadas com formas geométricas diferentes

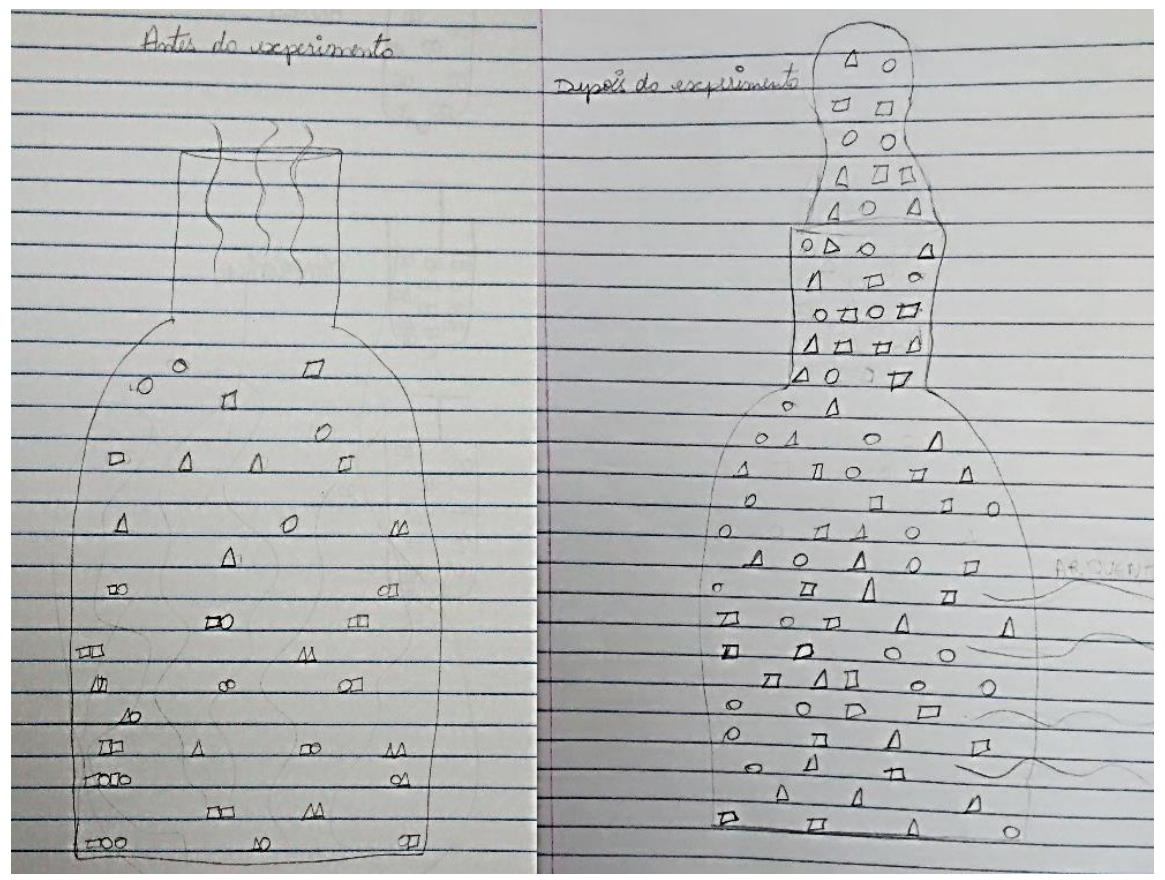

Fonte: do autor 
Outro aspecto avaliado nos modelos dos estudantes foi relativo a distribuição das entidades no espaço. Durante a análise das representações foi notado que ao representarem as entidades, alguns alunos as representaram distribuídas uniformemente em todo recipiente, enquanto outros desenharam concentradas em diferentes partes do recipiente.

Esse aspecto foi também avaliado por Novick e Nussbaum (1978) que analisaram os modelos elaborados pelos estudantes das séries finais do ensino fundamental ao representarem por meio de desenhos o ar em um kitassato antes e após ser submetido a ação de uma bomba de vácuo. A partir dos modelos foi avaliado se eles entendem os gases como sendo constituídos por partículas ou como algo contínuo e, ao observarem os desenhos feitos pelos colegas e escolherem qual acreditavam mais se adequar ao comportamento do gás, eram analisadas suas ideias quanto a natureza das partículas (particulada ou contínua) e como estas estão dispostas no espaço. As respostas de natureza particulada foram divididas nas categorias: "uniformemente espalhadas, mais espaços entre as partículas; uniformemente espalhadas, partículas expandem para o espaço vazio; concentradas em alguma parte do espaço confinado" (NOVICK, NUSSBAUM, 1978, p. 275, tradução nossa).

Baseado nessas categorias, foram analisadas as diferentes formas de distribuição das entidades representadas pelos estudantes após o aquecimento do ar. Os dados obtidos dessa análise são apresentados na Tabela 3 abaixo:

Tabela 3 - Como os estudantes distribuíram as entidades dos gases após o aquecimento

\begin{tabular}{|l|c|c|}
\hline \multicolumn{1}{|c|}{ Distribuição das entidades } & $\begin{array}{c}\text { Número de } \\
\text { modelos }\end{array}$ & $\begin{array}{c}\text { Percentual } \\
\text { de modelos }\end{array}$ \\
\hline $\begin{array}{l}\text { Uniformemente espalhados: aumento dos } \\
\text { espaços vazios }\end{array}$ & 10 & $45 \%$ \\
\hline $\begin{array}{l}\text { Uniformemente espalhados: diminuição dos } \\
\text { espaços vazios }\end{array}$ & 2 & $9 \%$ \\
\hline $\begin{array}{l}\text { Uniformemente espalhados: sem variação } \\
\text { aparente nos espaços vazios }\end{array}$ & 5 & $23 \%$ \\
\hline $\begin{array}{l}\text { Concentradas em alguma parte do espaço } \\
\text { confinado }\end{array}$ & 3 & $14 \%$ \\
\hline Outra forma de representação & 2 & $9 \%$ \\
\hline
\end{tabular}


A partir dos dados da Tabela 3, observa-se que nas representações de 10 estudantes ( $45 \%$ do total) houve um aumento nos espaços vazios entre as entidades, conforme foi explicado durante a atividade demonstrativo-investigativa. Na Figura 23 a seguir são apresentados dois exemplos de representações classificadas nessa categoria: no primeiro (Fig. 23a, à esquerda) a estudante utiliza o modelo de Dalton para representar as partículas que constituem os gases e, após o aquecimento do ar com o secador, elas ficam mais espaçadas, e no segundo (Fig. 23b, à direita) o estudante representa moléculas, utilizando o modelo de Dalton modificado e também se observa um aumento dos espaços entre as moléculas após o aquecimento.

Os resultados obtidos são semelhantes aos de Novick e Nussbaum (1978) que após os estudantes observarem os modelos dos colegas para representar o comportamento do ar quando submetido a ação da bomba de vácuo, em $46 \%$ das respostas entenderam a natureza dos gases como particulada e que estas partículas estão uniformemente separadas por todo espaço.

Figura 23 - Modelos de dois estudantes em que há um aumento dos espaços vazios entre as entidades
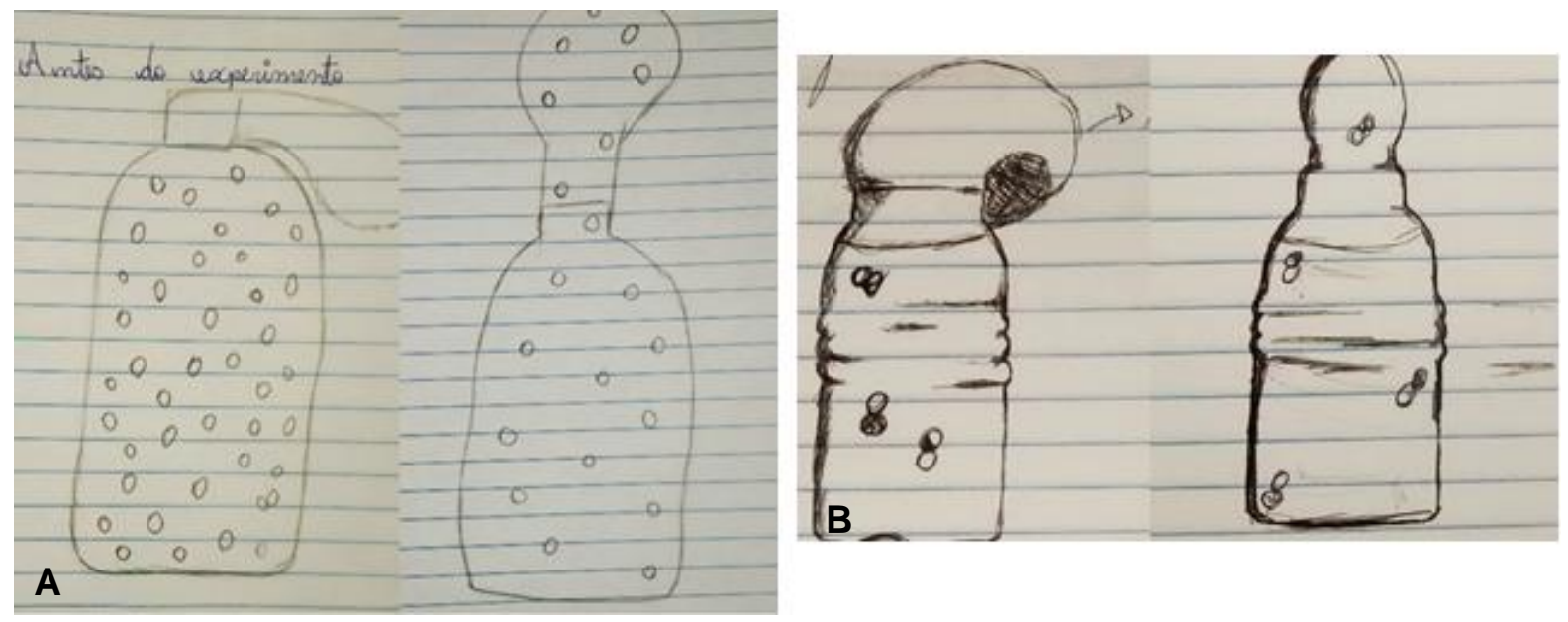

Fonte: do autor

Já em outros dois modelos, apresentados nas Figuras 22 e 24 foi observado a diminuição dos espaços vazios. Para o primeiro caso (Fig. 22), nota-se que a maior proximidade entre as entidades é decorrente do aumento no número de entidades após o aquecimento, enquanto no segundo (Fig. 24), a estudante atribui a dilatação do ar ao aumento de suas partículas. 
Figura 24 - Modelo de uma estudante em que se observa uma diminuição dos espaços vazios entre as entidades em decorrência do aumento no tamanho das partículas

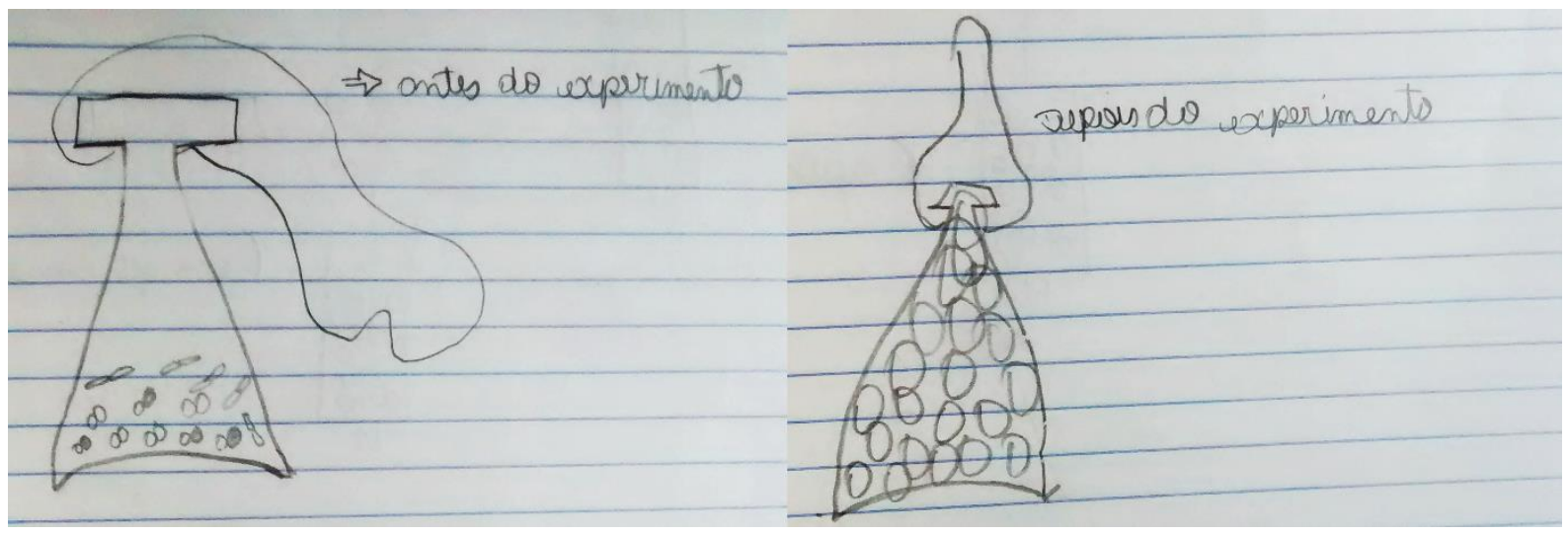

Fonte: do autor

Mortimer (1995) ao analisar as concepções atomistas dos estudantes a partir de um experimento semelhante ao realizado nessa pesquisa obteve exemplos similares ao representado pela aluna na Figura 24 e explica:

Esse conceito da dilatação das partículas é muito comum nos modelos atomistas intuitivos elaborados pelos estudantes. Faz parte de uma concepção que chamamos 'atomismo substancialista', uma vez que propriedades macroscópicas das substâncias, como dilatar e mudar de estado, são atribuídas aos átomos e moléculas. (MORTIMER, 1995, p. 24)

Também foram observados 5 modelos (aproximadamente $23 \%$ do total) em que, apesar dos estudantes representarem as entidades uniformemente separadas, não foram observados aumento nos espaços vazios quando comparadas as representações antes e após o aquecimento do ar. Em alguns desses casos, que podem ser observados na Figura 20a, os estudantes inicialmente utilizaram o modelo de Dalton modificado para representar os constituintes das substâncias, desenhando representações de moléculas diatômicas, e após o aquecimento desenharam modelos de átomos separados. Ou seja, eles entenderam que com o aumento da temperatura haveria um aumento nos espaços entre os átomos que constituem as moléculas, e não que a expansão do ar poderia ser explicada pelo aumento dos espaços vazios entre as moléculas.

. Essa dúvida foi colocada por uma estudante durante a realização da atividade que questionou se, ao aumentarmos a temperatura do ar, seria aumentado o espaço entre as moléculas ou se os átomos se separariam. Na transcrição apresentada 
abaixo, percebe-se que para responder a aluna, recorreu-se ao sistema conceitual novamente, além de retomar assuntos abordados no início do ano letivo, como é o caso de reações químicas:

Aluno: Você aumentou o espaço entre cada duas ou separou as duas?

Pesquisadora: A substância gás oxigênio é formada por uma molécula que é formada por dois átomos. Se eu tivesse os átomos de oxigênio separados eu ainda vou ter a substância oxigênio? Não. Porque se eu separo eu não vou ter mais a substância porque o que caracteriza a substância oxigênio é a molécula de gás oxigênio que é formada por dois átomos de oxigênio. Então você aumenta os espaços entre as moléculas.

Lembra que vocês estudaram lá no começo reações químicas (...)

Se eu separar eu não vou ter mais os constituintes da substância gás oxigênio eu vou ter um outro constituinte.

Para essa situação percebe-se que houve uma dificuldade no entendimento dos constituintes da substância, que no caso são as moléculas, como suas entidades formadoras. As substâncias são entendidas como formadas por átomos, sendo o gás oxigênio formado por átomos de oxigênio.

Analisando a transcrição do trecho da aula em que foi discutido como a Química explica o observado no macroscópico e o consequente aumento do número de modelos que representaram átomos separados após o aquecimento do ar, surgiu uma hipótese de um fator que pode ter contribuído para essa concepção equivocada do estudante, que é a utilização do termo partícula como sinônimo de molécula. A transcrição abaixo ilustra como o termo partícula foi utilizado nessa explicação:

Pesquisadora: Vamos pensar primeiramente no modelo de Dalton modificado. Quando eu aumento a temperatura a gente aumenta a agitação dessas partículas, quando você aumenta a agitação dessas partículas há um aumento dos espaços vazios entre elas.

Consideramos que, a partir dessa explanação, muitos estudantes podem ter entendido o termo partículas como sinônimo de átomos, eles concluíram que o aumento da temperatura levaria a um aumento dos espaços entre os átomos, resultando na separação entre os átomos das moléculas.

Entendendo que os conceitos científicos têm como principal característica serem organizados em um sistema hierárquico de inter-relações tendo relações lógicas bem estabelecidas entre esses conceitos, ao utilizarmos partículas como 
sinônimo de constituintes, o conceito de átomos é subordinado à ambos nesse sistema conceitual. Apesar disso, o conceito de partícula é constantemente utilizado significando átomo em muitos materiais didáticos e produções acadêmicas, e pouco utilizado em referência a moléculas ou estruturas unitárias. Portanto, para evitar conflitos conceituais sugerimos nesse trabalho a utilização dos termos constituintes em substituição ao termo partículas.

A utilização do termo constituinte como entidade que caracteriza a substância é bastante defendida por Rocha-Filho et al. (1988) e, pela presente análise pode-se afirmar que o não entendimento desse aspecto prejudica a compreensão do conceito de molécula, pois "dizer que a substância é composta de átomos é referir-se a uma de suas características, mas não aquilo que Ihe dá identidade" (ROCHA-FILHO el al., 1988, p.418).

Em outros casos, não há variação aparente nos espaços entre as moléculas devido aos estudantes desenharem mais moléculas após o aquecimento do que no estado inicial, como pode ser ilustrado na Figura 25 a seguir.

Figura 25 - Modelo de uma estudante em que se observa o aumento no número de moléculas após o aquecimento

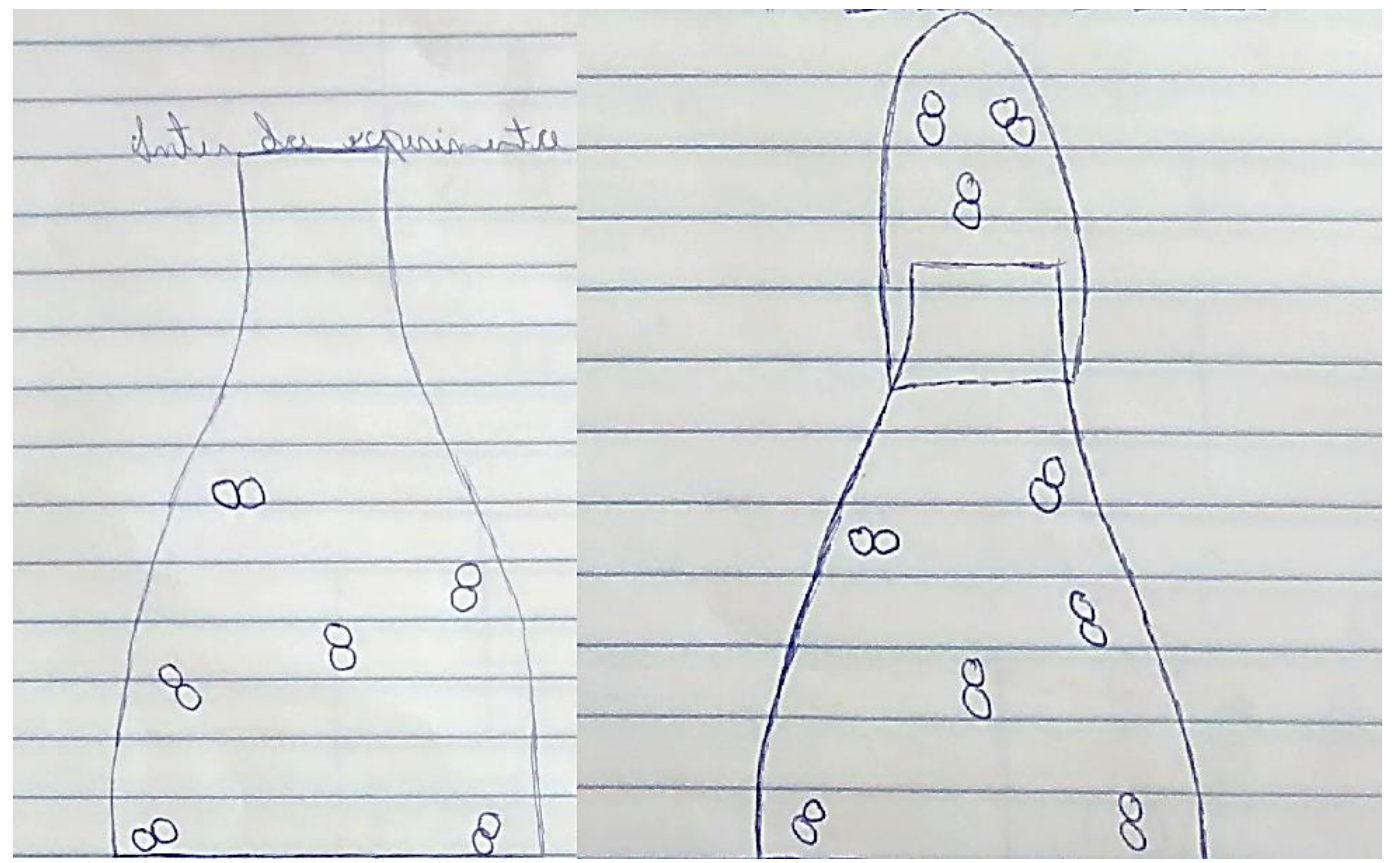

Fonte: do autor

Ao avaliar esse aspecto percebeu-se que esse problema apareceu na maioria dos modelos: 19 estudantes (mais de $86 \%$ do total) não se preocuparam com a 
conservação do número de entidades, representado mais delas após o aquecimento (Fig. 23b, 25) e, em apenas 3 modelos (aproximadamente 14\% do total) a quantidade de entidades é igual antes e após o processo.

A partir dessa dificuldade percebe-se que a ideia de conservação da matéria não é bem compreendida por parte dos estudantes mesmo em se tratando do entendimento de transformações físicas, como é o caso da dilatação dos gases.

Uma outra forma de distribuição observada em 3 modelos dos estudantes foi a representação das entidades concentradas em algum espaço do recipiente, conforme pode ser observada na Figura 20b e na Figura 26 a seguir.

Figura 26 - Modelo de uma estudante em que se observa a concentração de moléculas em determinados espaços do recipiente

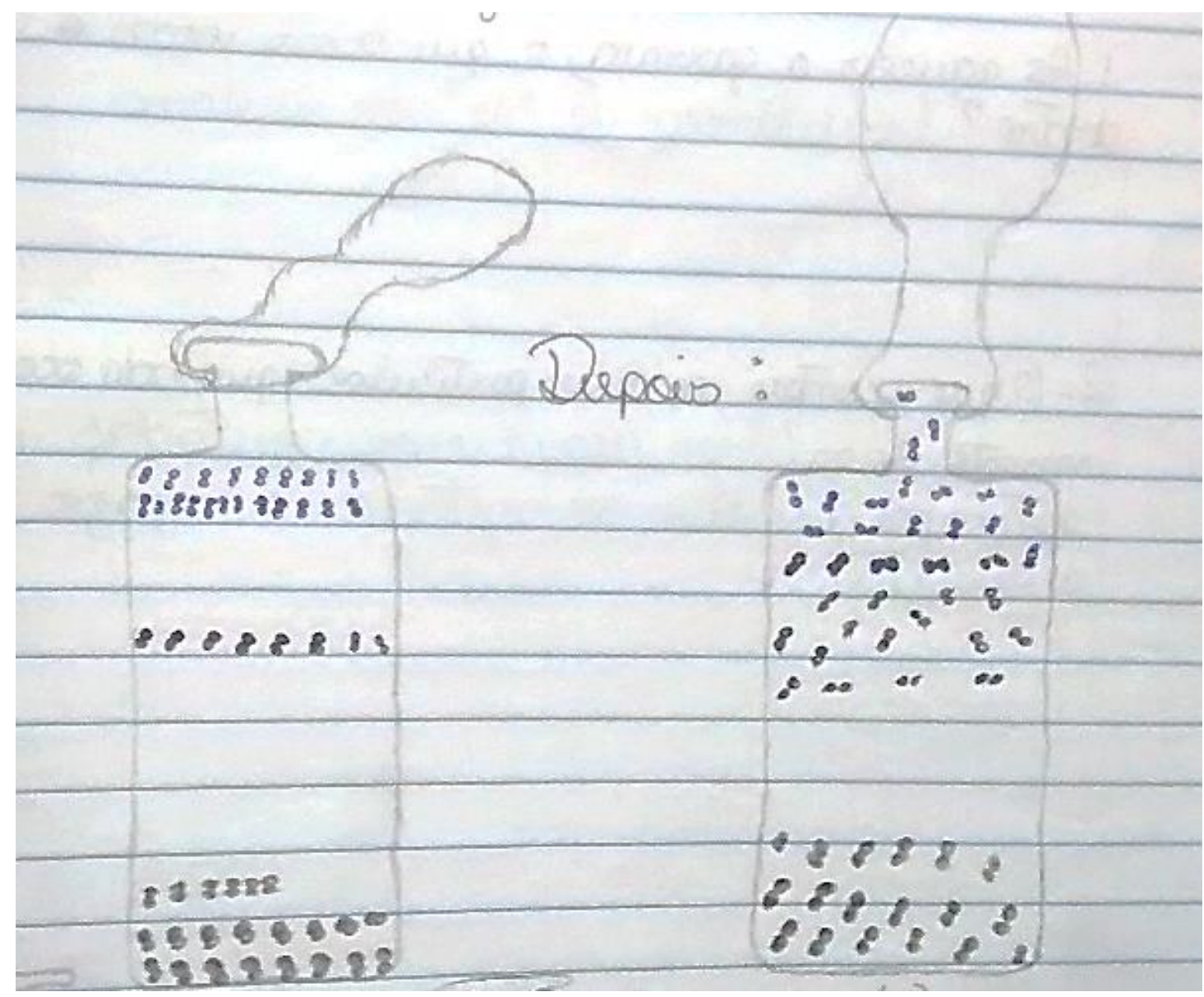

Fonte: do autor

Novick e Nussbaum (1978) relatam ideias semelhantes em seu trabalho no qual alguns dos estudantes participantes da pesquisa acreditavam que ao submeter o ar à ação de uma bomba de vácuo este ficaria concentrado alguma parte do recipiente. 
Porém, quando deparados com os modelos dos colegas, estes acabaram migrando para um modelo em que as partículas aparecem distribuídas por todo o ambiente.

A partir desses resultados percebe-se que mesmo após as discussões realizadas na aula anterior sobre as falhas do modelo de Dalton que levaram a sua modificação por Avogadro, os estudantes tiverem dificuldade em entender do que são constituídas as substâncias. Apesar disso, quando analisados os resultados obtidos no questionário anterior para a pergunta "Do que é constituído o gás nitrogênio, o gás oxigênio e o gás hidrogênio?", na qual, inicialmente nenhum estudante respondeu utilizando conceitos científicos de forma adequada e após a aula 9 estudantes o fizeram utilizando o conceito de molécula, e compará-los com essa aula, percebe-se que 9 estudantes representaram os constituintes dos gases como moléculas diatômicas em seus modelos. Percebe-se que um percentual significativo dos estudantes além de responderem que os gases são formados por moléculas, passaram a utilizar o conceito de moléculas na representação do fenômeno observado.

Deste modo, visando possibilitar uma melhor compreensão de como a Ciência explica o comportamento dos constituintes das substâncias, e mais especificamente, dos gases, é importante a realização de mais atividades que permitam aos estudantes construir e observar modelos. Para isso no módulo didático serão sugeridas estratégias que favoreçam esse processo.

Na segunda etapa deste encontro os estudantes observaram a compressão do ar dentro de uma seringa após ser exercida uma pressão manual sobre ela. Foi pedido que eles desenhassem os constituintes das substâncias presentes no ar dentro da seringa (1) antes, (2) durante e (3) após a compressão do êmbolo, utilizando o modelo de Dalton modificado, como pode ser observado no diálogo abaixo:

Pesquisadora: Agora eu tenho aqui uma seringa, nesse momento eu enchi a seringa de ar. Agora vocês façam o seguinte: peguem a última folha que vocês têm ai e vocês vão desenhar, eu quero que vocês representem os constituintes das substâncias segundo o modelo de Dalton modificado, ou seja, as substâncias são constituídas por partículas que são moléculas. Essas moléculas têm quantos átomos? Alunos: Dois.

Pesquisadora: Dois. Então vocês vão desenhar as moléculas no estado inicial aqui na seringa. Antes de vocês começarem a desenhar eu vou comprimir a minha seringa. O que acontece com as partículas aqui nesse momento?

Aluno: O espaço diminui 
Pesquisadora: Os espaços vazios entre as moléculas diminuem. $\mathrm{E}$ quando eu solto?

Aluno: O espaço aumenta.

Pesquisadora: $O$ espaço aumenta até o estado inicial.

A partir dos modelos elaborados pelos estudantes foram avaliados os mesmos aspectos relativos a expansão: natureza dos constituintes dos gases, distribuição das entidades no espaço e conservação do número de entidades antes, durante e após o experimento.

Com relação à natureza dos constituintes foram obtidos os resultados apresentados na Tabela 4:

Tabela 4 - Distribuição quanto à natureza dos diferentes modelos dos constituintes das substâncias para representar a compressão do ar desenhados pelos estudantes

\begin{tabular}{|c|c|c|c|c|}
\hline Natureza dos constituintes & \multicolumn{2}{|c|}{ Estado Inicial } & \multicolumn{2}{c|}{ Durante a compressão } \\
\hline & $\begin{array}{c}\text { Número de } \\
\text { modelos }\end{array}$ & $\begin{array}{c}\text { Percentual } \\
\text { de modelos }\end{array}$ & $\begin{array}{c}\text { Número de } \\
\text { modelos }\end{array}$ & $\begin{array}{c}\text { Percentual } \\
\text { de modelos }\end{array}$ \\
\hline Moléculas diatômicas & 14 & $64 \%$ & 14 & $64 \%$ \\
\hline Átomos isolados & 4 & $18 \%$ & 4 & $18 \%$ \\
\hline $\begin{array}{c}\text { Moléculas como aglomerado de átomos } \\
\text { (mais de dois átomos) }\end{array}$ & 2 & $9 \%$ & 2 & $9 \%$ \\
\hline Outras entidades & 2 & $9 \%$ & 2 & $9 \%$ \\
\hline
\end{tabular}

Observando a Tabela 4 acima, percebe-se que mais de $60 \%$ dos estudantes representaram os constituintes das substâncias utilizando desenhos de moléculas diatômicas, antes e durante a compressão, e menos de $20 \%$ representaram utilizando desenhos de átomos isolados. São apresentados exemplos dessas representações na Figura 27:

Ao compararmos esses resultados com os apresentados na Tabela 2, referentes a representação dos constituintes após o aquecimento do ar em que apenas $36 \%$ dos estudantes desenharam moléculas diatômicas, é observada uma melhora significativa no número de estudantes que utilizaram o modelo de Dalton modificado antes e após a compressão do ar na seringa. 
Figura 27 - Exemplos de representações dos constituintes das substâncias, moléculas diatômicas presentes no ar antes, durante e após a compressão na seringa
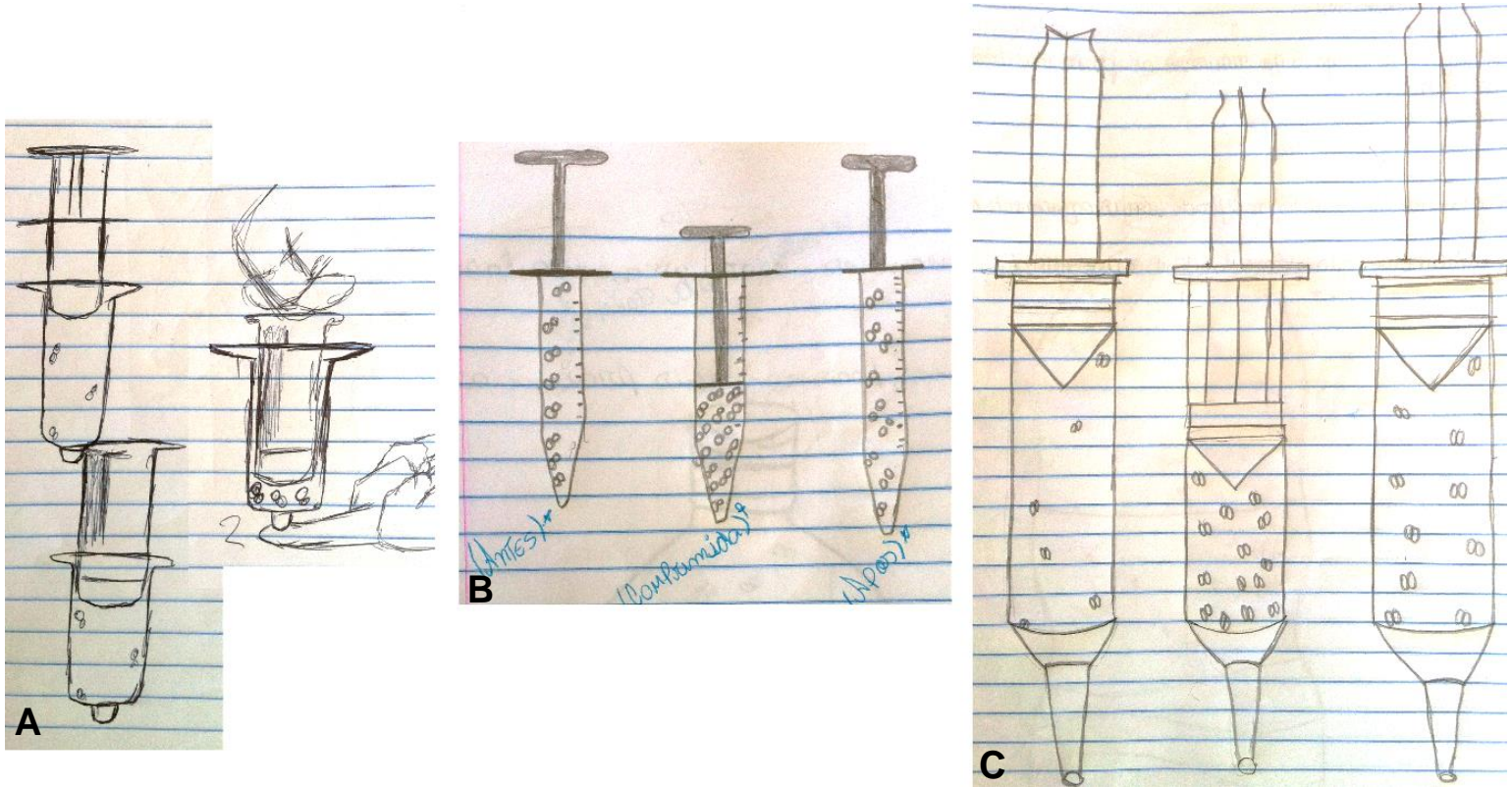

Fonte: do autor

Dentre as possíveis hipóteses para o aumento no número de estudantes que utilizaram o modelo proposto na segunda atividade, entendemos que com a realização de mais atividades nas quais os estudantes são instigados a representar modelos das interpretações submicroscópicas discutidas pelo professor, eles vão ficando cada vez mais familiarizados com as características do modelo.

Além disso, a dificuldade dos estudantes em conseguirem representar corretamente a expansão dos gases pode ser atribuída a complexidade relacionada a imaginar uma certa quantidade de molécula (constituintes) ficando mais afastadas o que explicaria o enchimento da bexiga. $O$ entendimento dessa ideia envolve uma concepção espontânea de que o aumento da temperatura leva a um aumento no grau de desordem, estando associado a entropia do sistema. Assim, na percepção de alguns alunos para o primeiro caso a expansão possibilitaria a separação entre os átomos que constituem a molécula, o que não acontece para o segundo caso, já que as moléculas ficam mais próximas.

Também são observados melhores resultados quanto à distribuição dos constituintes na seringa (Tabela 5) na representação da compressão do ar. Mais de $60 \%$ dos estudantes representaram os constituintes mais próximos uns dos outros quando o êmbolo da seringa foi comprimido, exemplos dessas representações são apresentados na Figura 27. Se observarmos a Tabela 3 e compararmos os resultados 
com os referentes a compressão (Tabela 5), percebe-se que apenas $45 \%$ dos estudantes representaram um aumento nos espaços vazios para explicar a expansão, até porque alguns representaram uma separação dos átomos que constituíam as moléculas, o que levou a uma não variação aparente nos espaços vazios entre as moléculas, enquanto essa concepção não ocorre para a compressão.

Tabela 5 - Como os estudantes distribuíram as entidades dos gases após a compressão

\begin{tabular}{|c|c|c|}
\hline Distribuição das entidades & $\begin{array}{c}\text { Número de } \\
\text { respostas }\end{array}$ & $\begin{array}{c}\text { Percentual } \\
\text { de respostas }\end{array}$ \\
\hline $\begin{array}{c}\text { Uniformemente espalhados: diminuição dos } \\
\text { espaços vazios }\end{array}$ & 14 & $63 \%$ \\
\hline $\begin{array}{c}\text { Uniformemente espalhados: sem variação } \\
\text { aparente nos espaços vazios }\end{array}$ & 3 & $14 \%$ \\
\hline $\begin{array}{c}\text { Concentradas em alguma parte do espaço } \\
\text { confinado }\end{array}$ & 2 & $9 \%$ \\
\hline \begin{tabular}{c} 
Outra forma de representação \\
\hline
\end{tabular} & 3 & $14 \%$ \\
\hline
\end{tabular}

A partir desses resultados, percebe-se que a interpretação submicroscópica que explica a expansão do ar na garrafa tem um maior grau de complexidade do que a que explica a compressão. Pensando nisso, é sugerida uma inversão na ordem das atividades no módulo didático iniciando com a atividade de compressão da seringa que obtivemos melhores resultados e acreditamos ser mais facilmente entendida, e depois para a expansão do ar, na qual os estudantes apresentaram mais dificuldades.

Quanto à variação do número de constituintes após a compressão (Tabela 6) foi observado que a maioria dos estudantes não se preocupam com a conservação do número de moléculas antes e após a compressão. Mesmo com a pequena melhora quando comparamos com a representação da expansão (no primeiro caso três estudantes representaram o mesmo número de molécula e no segundo quatro estudantes), mais de $70 \%$ dos alunos não mantiveram o mesmo número de constituintes antes e após a compressão. Isso ocorre principalmente porque para representarem a diminuição dos espaços entre as moléculas quando o êmbolo é comprimido, muitos estudantes desenham mais moléculas para que elas fiquem mais próximas umas das outras, exemplos desses modelos são apresentados nas Figuras $27 b$ e $27 c$. 
Tabela 6 - Distribuição das respostas dos estudantes quanto à variação do número de constituintes após a compressão

\begin{tabular}{|c|c|c|}
\hline Quantidade de entidades & $\begin{array}{c}\text { Número de } \\
\text { respostas }\end{array}$ & $\begin{array}{c}\text { Percentual de } \\
\text { respostas }\end{array}$ \\
\hline Mesmo número de entidades & 4 & $18 \%$ \\
\hline Diminui o número de entidades & 3 & $14 \%$ \\
\hline Aumenta o número de entidades & 13 & $60 \%$ \\
\hline Não se aplica & 2 & $9 \%$ \\
\hline
\end{tabular}

Apenas quatro estudantes (18\% do total) consideraram que nas seringas deveriam estar representadas com o mesmo número de constituintes após a compressão. Nas Figuras 27a é apresentado um exemplo dessas representações. Observando esse resultado percebemos a necessidade de se trabalhar a ideia de conservação da matéria no módulo didático.

\subsection{ELABORANDO A EXPRESSÃO REPRESENTACIONAL DE UMA REAÇÃO QUÍMICA}

O terceiro encontro foi iniciado com um vídeo "Baixa oxigenação pode causar mais mortes de peixes no Rio Piracicaba". Após assistirem ao vídeo disponível na reportagem, os estudantes foram questionados sobre a possibilidade de os peixes morrerem por falta de oxigênio dentro da água. Essa atividade teve como objetivo verificar se os estudantes utilizariam o sistema conceitual (Fig. 14) para responder à questão proposta, entendendo a água do rio como sendo um material por ser formada por várias substâncias, dentre elas o gás oxigênio.

Os estudantes tentaram responder à pergunta proposta como pode ser observado na transcrição abaixo:

Pesquisadora: A gente está discutindo o seguinte: como os peixes morreram por falta de oxigênio sendo que eles estavam na água?

Aluno: Na água tem moléculas de oxigênio. 
No trecho acima, mesmo que o estudante não afirme que a água é um material e não utilize o termo substância para se referir ao oxigênio, podemos perceber que ele entende que na água do rio existe, além da substância água, moléculas de oxigênio. Essa percepção é muito importante pois nota-se que o aluno sabe diferenciar o átomo presente na substância água do constituinte do gás oxigênio. Conforme explica Rocha-Filho et al. (1988): "o estudo dos átomos tem sentido para o químico apenas quando concebidos do 'ponto de vista do constituinte', isto é, como parte destes" (ROCHA-FILHO et al., 1988, p. 419), e esse aluno consegue perceber essa diferença em se tratando do átomo de oxigênio e do constituinte da substância oxigênio.

Após essa discussão foi feita a atividade demonstrativo-investigativa: eletrólise da água. Nesse experimento tem-se como observações macroscópicas a formação de bolhas (liberação de gás) nos tubos que ficam dentro do recipiente contendo água e sulfato de sódio. Como interpretação submicroscópica, foi explicado aos estudantes que no fenômeno observado ocorre uma reação química em que a substância água é decomposta em duas outras substâncias, que são o gás oxigênio e o gás hidrogênio:

Pesquisadora: A água é formada por moléculas de água e a gente promove aqui, com fornecimento de energia, uma reação química e nessa reação química forma gás oxigênio e gás hidrogênio.

Um dos estudantes questiona se não seria uma separação, já que na água tem hidrogênio e oxigênio:

Aluno: Eu acho que não. Por que se a água tem hidrogênio e tem oxigênio eu acho que só tá separando, se tá saindo gás oxigênio e gás hidrogênio só tá separando.

A ideia do estudante poderia ser devido a um entendimento equivocado da identidade da substância água como sendo uma porção de átomos de hidrogênio e oxigênio, e que seriam separados na eletrólise, ou também ele poderia estar se referindo as substâncias oxigênio e hidrogênio presentes na água (material). Durante a atividade, entendemos que o estudante não estava apresentando as ideias dentro do sistema conceitual, e sim utilizando sua concepção prévia de que a água é formada de átomos de hidrogênio e oxigênio. Por isso, para responder a essa pergunta foi utilizado o sistema conceitual Natureza da Matéria (Fig. 6), sendo enfatizado que a 
substância água é formada por constituintes, moléculas de água, e estas são formadas por hidrogênio e oxigênio:

Pesquisadora: Na verdade, a água é formada não por hidrogênio e oxigênio, ela é formada por moléculas de água e essas moléculas de água são formadas por (átomos de) hidrogênio e oxigênio. Não é uma separação, é uma reação química. Vocês sabem o que acontece em uma reação química?

Aluno: Transforma em outras substâncias.

Desta forma, antes do conceito de átomo há um conceito supraordenado que é o de constituinte (para o caso em questão, molécula de água), sendo muito importante que os estudantes utilizem esse conceito em suas explicações submicroscópicas.

Após essa explicação foi pedido que os alunos representassem, usando massinha de modelar, os constituintes das substâncias água, gás hidrogênio e gás oxigênio, segundo o modelo de Dalton modificado. A maioria dos estudantes representou os gases como moléculas diatômicas e a molécula de água com duas esferas representando o hidrogênio e uma o oxigênio, exemplos dessas representações são apresentados na Figura 28.

A partir da observação dos modelos elaborados foi pedido que os estudantes escrevessem a equação química que representa a decomposição da água observada. Nessa atividade eles apresentaram bastante dificuldade questionando o que é uma equação química, o que é reagente e produto de uma reação. O diálogo a seguir retrata algumas das dúvidas dos estudantes:

Pesquisadora: No processo de eletrólise da água, a gente tá tendo uma reação química não tá? Nessa reação química eu tô formando o quê? Quais são os gases?

Alunos: Oxigênio mais hidrogênio.

Pesquisadora: Quem é o meu reagente?

Aluno: Oxigênio e hidrogênio.

Pesquisadora: Não. Isso é o que está sendo formado. Quem é o meu reagente?

Alunos: $A$ água.

Pesquisadora: A água. E o que está sendo formado?

Aluno: $\mathrm{H}_{2} \mathrm{O}$. 
Figura 28 - Modelos de massinha de modelar que representam os constituintes das substâncias envolvidas na eletrólise da água, sendo elas: água, gás oxigênio e gás hidrogênio
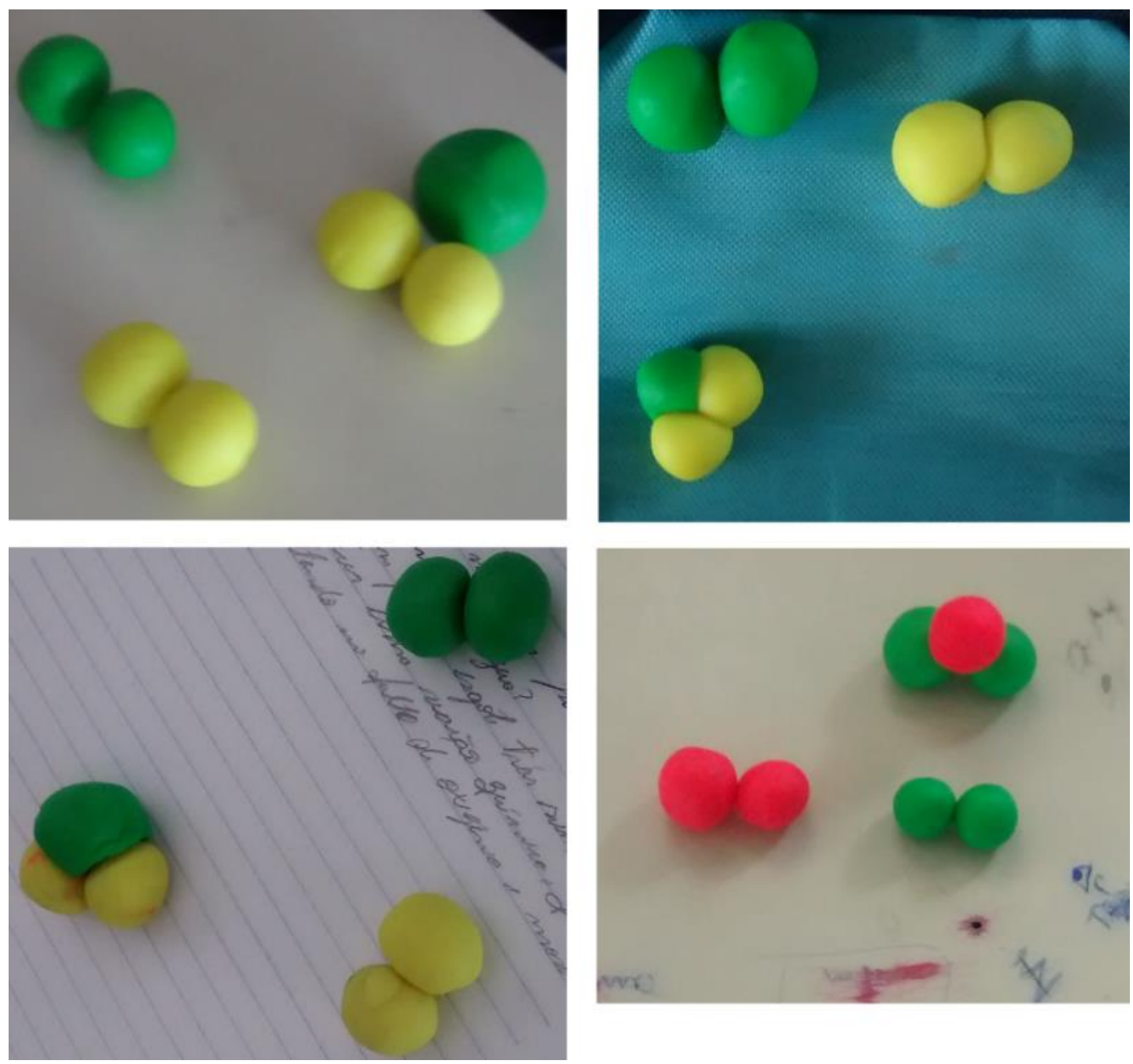

Fonte: do autor

Por isso, no módulo didático sugere-se que antes de o professor pedir que os estudantes escrevam a equação química, ele explique a partir da reação observada os conceitos de reagente, produto e até mesmo de uma seta de reação. Além disso, inicialmente eles devem escrever as fórmulas que representam cada um dos constituintes das substâncias $\left(\mathrm{H}_{2}, \mathrm{O}_{2}\right.$ e $\left.\mathrm{H}_{2} \mathrm{O}\right)$ observando os modelos construídos com massinha, e posteriormente escrevam a expressão representacional da eletrólise da água.

Tendo percebido essas dificuldades durante a atividade, buscou-se explicar os conceitos de reagente e produto da reação apresentada para possibilitar que os 
estudantes conseguissem construir expressões representacionais para esses processos, conforme pode ser observado na transcrição abaixo:

Pesquisadora: Antes de começar a minha reação o que eu tinha ali dentro do meu copo?

Aluna: Antes do que?

Pesquisadora: Antes de eu começar a minha reação. Antes de eu colocar ali a pilha e a tampinha?

Aluna: Tinha água e sal.

Pesquisadora: Esse é o meu reagente. A água. E quem é o meu produto? (É) o que eu tô formando: o gás hidrogênio e o gás oxigênio. Entendeu?

Aluno: Eu entendi.

Desta forma, a partir da observação dos modelos concretos, muitos estudantes conseguiram escrever a equação química representando corretamente os constituintes das substâncias envolvidas na eletrólise da água. Na Figura 29 é apresentada a distribuição das respostas que foram classificadas em totalmente corretas, parcialmente corretas, incorretas e não respondeu:

Figura 29 - Classificação das expressões representacionais para eletrólise da água representadas pelos estudantes

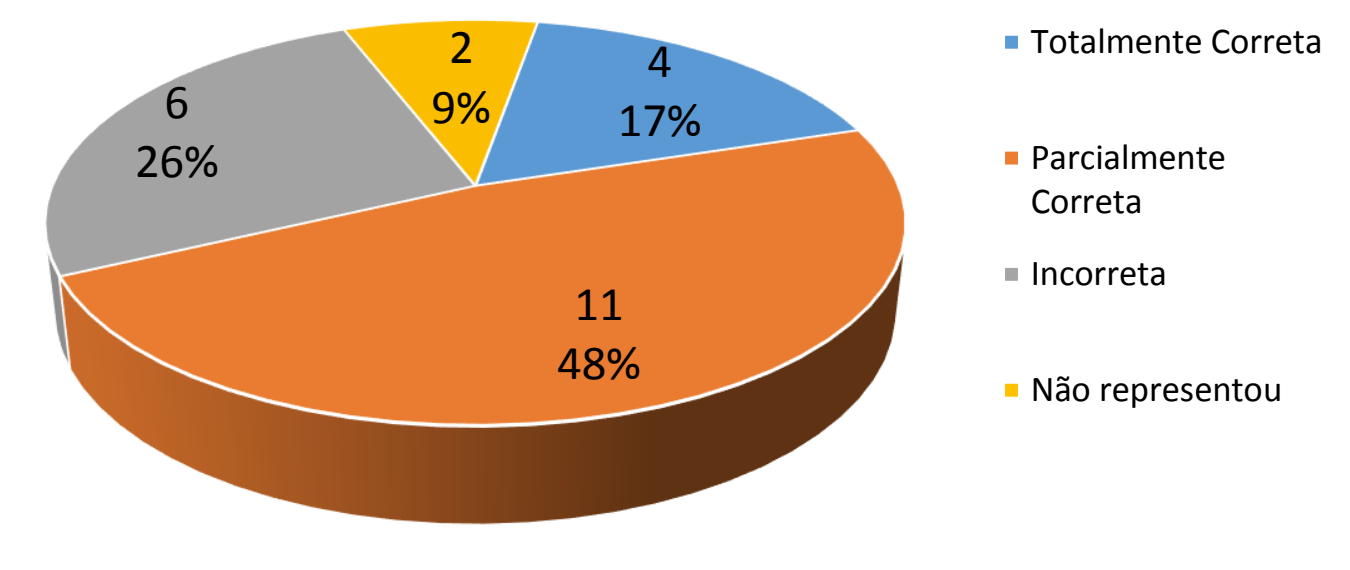

Para essa classificação (Fig. 29) foram consideradas totalmente corretas as respostas na qual o estudante apresentou um modelo (representação por meio de um desenho dos constituintes da reação) que se adequava as ideias de Dalton modificadas por Avogadro, e a partir dele, escreveu a equação química considerando o número de átomos que formam os constituintes de cada substância e, por isso, fizeram o devido balanceamento da equação. Um exemplo de resposta considerada totalmente correta é apresentado na Figura 30. 
A discussão sobre a conservação no número de átomos que formam os constituintes das substâncias antes (no reagente) e após (no produto) a reação foi discutida ao final do encontro e o tempo da aula não foi suficiente para que todos compreendessem. Para isso foi perguntado aos estudantes como eles poderiam explicar o fato de tendo como constituinte a molécula de água (que tem dois átomos de hidrogênio e um de oxigênio) ser possível obter o constituinte do gás oxigênio (com dois átomos de oxigênio) e o do gás hidrogênio (com dois átomos de hidrogênio). Foram obtidas respostas como:

Aluno: Eu acho que quebrou esse aqui (se referindo à um átomo) e formou dois. Eu acho que na reação química ele se quebraram.

Aluno: Ô professora mas dentro desse tubo tem várias moléculas de água eu acho que as moléculas de água e elas liberam esse átomo.

Com a discussão dessas respostas introduziu-se a ideia de conservação da matéria, pois segundo o modelo que estávamos utilizando, eles não podem ser criados e nem destruídos.

A partir dessas discussões, quatro estudantes (aproximadamente $17 \%$ do total) conseguiram desenhar o modelo, e a partir dele, representar os constituintes das substâncias, além de realizar o balanceamento da equação de forma adequada. $\mathrm{Na}$ Figura 30 é apresentado um exemplo de expressão representacional considerada totalmente correta:

Figura 30 - Exemplo de expressão representacional transcrita a partir do modelo concreto da eletrólise da água escrita um estudante e classificada como totalmente correta

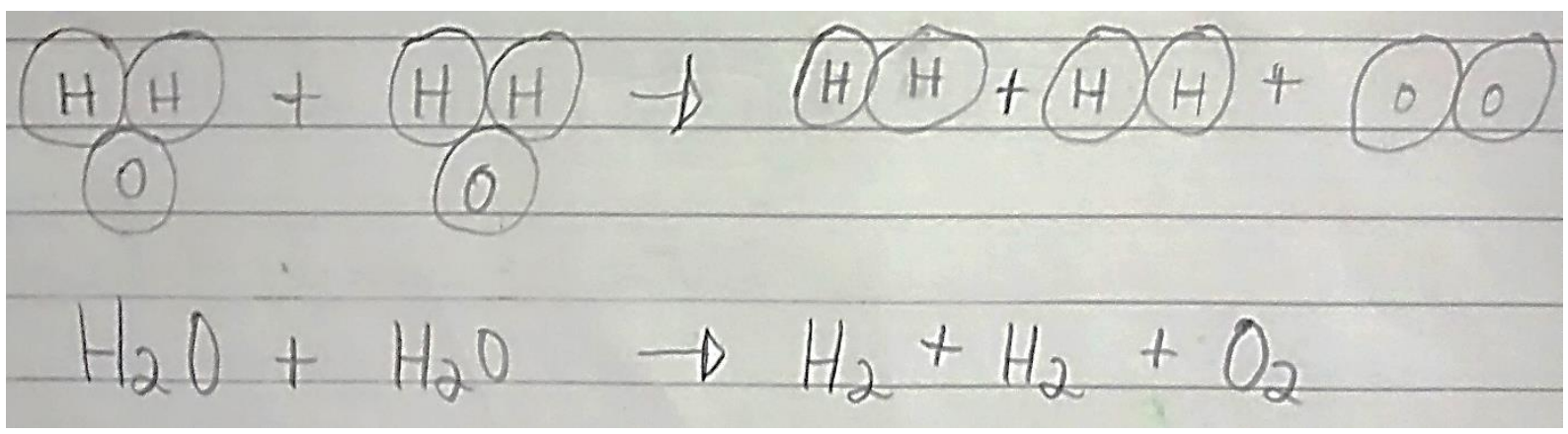

Fonte: do autor

A maioria dos estudantes (11 deles, correspondendo aproximadamente $48 \%$ do total) escreveram as expressões representacionais de forma parcialmente correta. Foram consideradas nessa categoria as seguintes respostas: (1) os modelos foram 
desenhados adequadamente, mas a equação química não corresponde ao que foi representado no modelo; (2) os modelos foram desenhados adequadamente, a equação química corresponde ao que foi representado no modelo, porém não é considerada a conservação da matéria nas expressões; (3) os modelos não foram desenhados adequadamente, mas a equação química foi corretamente representada. O número de respostas classificadas como parcialmente corretas para cada uma dessas três categorias é apresentado na Figura 31, e exemplos dessas expressões representacionais na Figura 32.

Figura 31 - Expressões representacionais classificadas como parcialmente corretas

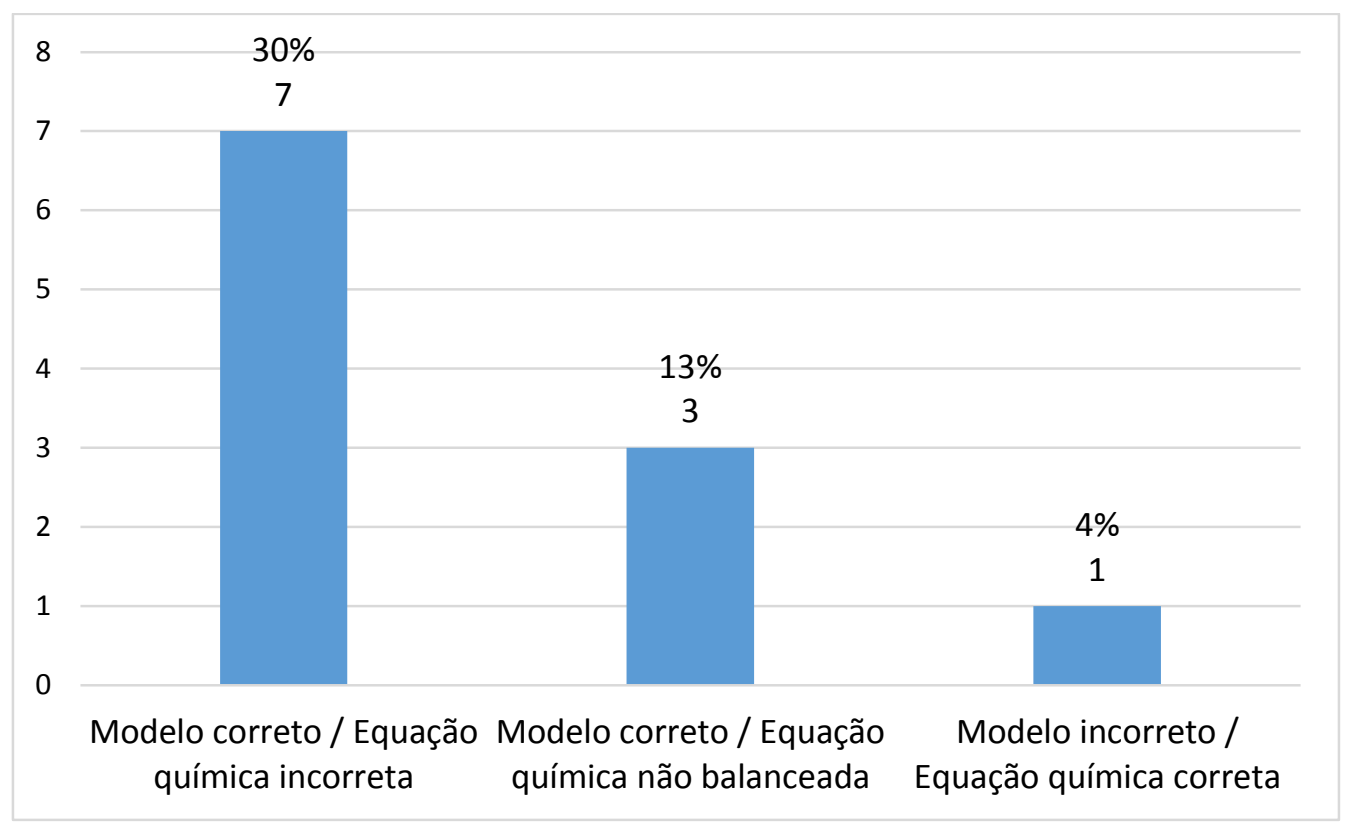

Figura 32 - Exemplos de expressões representacionais da eletrólise da água escritas pelos estudantes e classificadas como parcialmente corretas
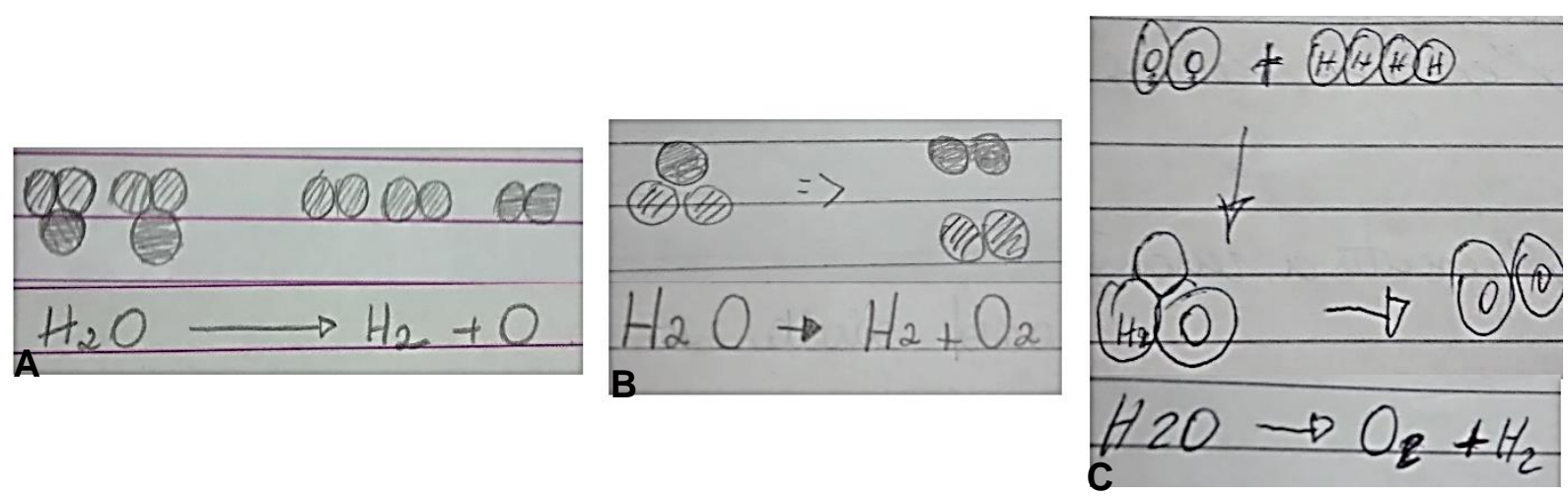

Fonte: do autor 
Sobre as expressões representacionais classificadas como parcialmente corretas (Fig. 31, 32) foi observado que a maioria dos estudantes, 7 no total (aproximadamente $30 \%$ do total), desenharam os constituintes das substâncias de forma adequada, mas não conseguiram transcrever esse modelo para a linguagem química corretamente (Fig. 32a). Outros três (13\% do total), apesar de não fazerem o balanceamento da reação, desenharam o modelo e escreveram a equação química de forma adequada (Fig. 32b). Apenas um estudante não representou a reação apresentada utilizando os modelos adequadamente mas conseguiu escrever a equação química de forma parcialmente correta (Fig. 32c).

Ao analisar esses resultados nota-se que a maioria dos estudantes conseguiu apresentar expressões representacionais adequadas para descrever, por meio de modelos simbólicos (equação química) e/ou concretos (esferas feitas de massinha), o fenômeno observado e discutido na aula.

Mesmo com a utilização dos modelos, ainda houveram 6 estudantes (aproximadamente $26 \%$ do total) que construíram os modelos e escreveram a equação química de forma incorreta. Nessas representações algum dos gases com a representação de apenas um átomo e não como moléculas diatômicas.

Considerando que mais da metade dos estudantes conseguiram representar equações químicas de forma correta ou parcialmente correta, entendemos que as atividades propostas contribuíram para esse entendimento. Não houve tempo para discutir com os estudantes a necessidade de se utilizar símbolos nas equações químicas para representar os estados de agregação das substâncias. Para isso, no módulo didático são sugeridas mais aulas para discussão das expressões representacionais do conhecimento químico. 


\section{CONSIDERAÇões FinaIS}

Partindo do objeto de pesquisa do presente trabalho, que buscava investigar o uso de sistemas conceituais hierarquicamente organizados e estratégias envolvendo modelos e modelagens para facilitar na transição entre os três níveis do conhecimento químico, podemos tecer algumas considerações.

Quanto ao nível macroscópico, percebeu-se que a utilização do sistema conceitual "formas de apresentação da matéria" apresentou resultados bastante satisfatórios para a introdução de conceitos científicos que envolvem o tema atmosfera. Antes da aplicação da metodologia proposta, quando perguntado aos estudantes o que é atmosfera, muitos utilizaram conceitos cotidianos e, após o primeiro encontro no qual foram apresentados os sistemas conceituais e atividades demonstrativo-investigativas, a grande maioria respondeu à questão operando com conceitos científicos.

Sobre o conceito de ar, podemos observar que os resultados também foram satisfatórios, porém com um percentual significativo de estudantes que continuaram utilizando conceitos cotidianos mesmo após a aplicação da proposta, principalmente relacionando o significado de ar à sua função, sendo "aquilo que respiramos". Faz-se necessário que sejam desenvolvidas atividades que envolvam a discussão desse conceito dentro do sistema conceitual para que esses significados sejam melhor entendidos pelos alunos. Para isso, na interface Ciência-Tecnologia-Sociedade (CTS) podem ser discutidos os métodos de obtenção dos diferentes gases presentes no ar e para quais finalidades são utilizados, por exemplo, falando sobre a extração da substância nitrogênio do ar atmosférico e sua utilização na conservação de células reprodutivas. Dessa forma, o ar pode ser entendido pelos estudantes como um material do qual podem ser obtidas diferentes substâncias.

Observou-se também que quando são abordadas as interpretações submicroscópicas apenas de forma expositiva por meio de relatos do professor, alguns estudantes sentem dificuldade em entender como a Ciência explica os fenômenos devido a impossibilidade de observar o que ocorre com os constituintes das substâncias e a dificuldade em imaginar cada uma dessas entidades. As atividades envolvendo modelos e modelagem foram importantes para minimizar esses problemas, pois os estudantes foram instigados a elaborar modelos mentais e 
representa-los de forma concreta, permitindo que tivéssemos acesso as concepções desses estudantes e conhecêssemos suas dificuldades. Além disso, essas atividades possibilitaram que fossem discutidos aspectos da história da Ciência, quando foram abordados os modelos históricos de Dalton e as contribuições de diferentes cientistas (Gay-Lussac e Avogadro) que resultaram em mudanças nesse modelo, e da natureza da Ciência, pois o conhecimento científico foi discutido como construção humana, tendo limitações e estando sujeito a mudanças, conforme é recomendado nos $\mathrm{PCN}+$.

A partir desses modelos foram percebidas algumas concepções equivocadas quanto a natureza das substâncias como, por exemplo, são formadas por aglomerados de átomos, ou por átomos isolados, mostrando a dificuldade na compreensão do conceito de constituinte (molécula, fórmula unitária, etc.). Com as discussões realizadas, consideramos que houveram avanços no entendimento dos conceitos, pois muitos estudantes responderam utilizando conceitos científicos quando perguntados sobre os constituintes das substâncias: oxigênio, nitrogênio e hidrogênio.

O uso do conceito de constituinte se mostrou essencial, pois ao explicarmos a dilatação do gás como sendo decorrente do aumento dos espaços vazios entre as "partículas", alguns estudantes que ao desenharem modelos, antes do aquecimento, representando os constituintes dos gases como moléculas diatômicas (modelo de Dalton modificado), após a dilatação representaram como átomos isolados, entendendo que houve um aumento nos espaços entre as "partículas" que, para eles seriam os átomos. Para evitar esse tipo de confusão conceitual, defendemos a discussão da natureza da matéria utilizando a ideia de constituinte, favorecendo que os alunos compreendam que o constituinte é o que dá identidade e caracteriza uma substância.

Quanto à elaboração da expressão representacional, foi observado que a maioria dos estudantes conseguiu construir uma representação utilizando modelos concretos dos constituintes das substâncias envolvidas na equação, e a partir deles desenhar modelos adequados para representar a reação de eletrólise da água. Porém, alguns estudantes, mesmo representando os constituintes das substâncias oxigênio e hidrogênio como moléculas diatômicas, não conseguiram transcrever esses modelos para linguagem química de forma adequada, representando o oxigênio como formado por átomos isolados. Isso pode ser resultante da falta de tempo hábil para a discussão de como são representados os fenômenos por meio da linguagem 
química, sendo dada maior ênfase na discussão dos modelos concretos. Sugerimos que a linguagem química seja trabalhada com os estudantes, abordado o significado dos símbolos presentes em fórmulas e equações químicas (que podem ser entendidos a partir do modelo de Dalton modificado), para que os estudantes percebam que esta é uma outra forma de representação, um modelo simbólico, também usado para representar o fenômeno observado. É importante que os professores entendam que a linguagem química é muito diferente da cotidiana, sendo necessário definir detalhadamente o significado de cada um dos símbolos presentes em uma equação química.

Esses resultados também explicam a dificuldade no aprendizado de cálculos estequiométricos, pois muitos estudantes não entendem: o significado dos símbolos utilizados nas expressões representacionais envolvendo equações químicas; as substâncias como sendo formadas por constituintes, acreditando que são aglomerados de átomos; a real necessidade em escrever equações químicas em que sejam consideradas a conservação da matéria. 
ALVES, D. P. Formação continuada para professores de ciências nas séries iniciais: uso de modelos e modelagem para introdução de conceitos químicos. 2012. (Mestrado em Ensino de Ciências). Programa de Pós-Graduação em Ensino de Ciências, Universidade de Brasília (UnB), Brasília.

ARAÚJO, D. X. D.; SILVA, R. R.; TUNES, E. O conceito de substância em química apreendido por alunos do ensino médio. Química Nova, v. 18, n. 1, p. 80-90, 1995.

Baixa oxigenação pode causar mais mortes de peixes no Rio Piracicaba. 2014. Disponível em: < http://g1.globo.com/sp/piracicaba-regiao/noticia/2014/02/baixaoxigenacao-pode-causar-mais-mortes-de-peixes-no-rio-piracicaba.html >. Acesso em: 24/05/2015.

BRASIL. Diretrizes Curriculares Nacionais Gerais da Educação Básica. MEC. Brasília: MEC 2013.

PCN+ ensino médio: orientações educacionais complementares aos Parâmetros Curriculares Nacionais. MEC. Brasília: MEC/Semtec. Ciências da natureza, matemática e suas tecnologias. 2002.

CHAIB, N. N. Teoria Atômico-Molecular. SÃO PAULO (Estado) Secretaria de Educação. Coordenadoria de Estudos e Normas Pedagógicas. In: (Ed.). Ensino de Química: dos fundamentos à prática. São Paulo: SE/CENP, v.1, 1988. p.21-26.

CHASSOT, A. Pra que(m) é útil o ensino? 3. ljuí: Unijuí, 2013.

FREIRE, P. Pedagogia do Oprimido. 41. Rio de Janeiro: Paz e Terra, 2005.

GILBERT, J. Models and Modelling: Routes to More Authentic Science Education. International Journal of Science and Mathematics Education, v. 2, n. 2, p. 115130, 2004/06/01 2004. ISSN 1571-0068. Disponível em: < http://dx.doi.org/10.1007/s10763-004-3186-4 >.

GILBERT, J.; TREAGUST, D. Introduction: Macro, Submicro and Symbolic Representations and the Relationship Between Them: Key Models in Chemical Education. In: GILBERT, J. e TREAGUST, D. (Ed.). Multiple Representations in Chemical Education: Springer Netherlands, v.4, 2009. cap. 1, p.1-8. (Models and Modeling in Science Education). ISBN 978-1-4020-8871-1.

GOMES, V. B. Divulgação Científica na Formação Inicial de Professores de Química. 2012. 139 (Mestrado em Ensino de Ciências). Programa de PósGraduação em Ensino de Ciências, Universidade de Brasília (UnB), Brasília.

HODSON, D. Hacia un enfoque más crítico del trabajo de laboratorio. Enseñanza de las ciencias: revista de investigación y experiencias didácticas, v. 12, n. 3, p. 299-313, 1994. 
JOHNSTONE, A. H. Chemical education research in Glasgow in perspective. Chemistry Education Research and Practice, v. 7, n. 2, p. 49-63, 2006. ISSN 1109-4028. Disponível em: < http://dx.doi.org/10.1039/B5RP90021B >.

JOHNSTONE, A. H. Macro and Microchemistry. The School Science Review, v. 64, n. 227, p. 377-379, 1982.

. You Can't Get There from Here. Journal of Chemical Education, v. 87, n. 1, p. 22-29, 2010/01/01 2009. ISSN 0021-9584. Disponível em: < http://dx.doi.org/10.1021/ed800026d >. Acesso em: 2014/07/11.

JUSTI, R. La enseñanza de ciencias basada en la elaboración de modelos.

Enseñanza de las ciencias: revista de investigación y experiencias didácticas, v. 24, n. 2, p. 173-184, 2006. Disponível em: < http://www.raco.cat/index.php/Ensenanza/article/view/75824 >.

. Modelos e Modelagem no Ensino de Química: Um olhar sobre aspectos essenciais pouco discutidos. In: SANTOS, W. L. P. D. e MALDANER, O. A. (Ed.). Ensino de Química em Foco. ljuí, RS: Unijuí, 2011. cap. 8, p.209-230.

JUSTI, R.; GILBERT, J. Teachers' views on the nature of models. International Journal of Science Education, v. 25, n. 11, p. 1369-1386, 2003/11/01 2003. ISSN 0950-0693. Disponível em: < http://dx.doi.org/10.1080/0950069032000070324 >. Acesso em: 2015/05/31.

JUSTI, R. S.; GILBERT, J. K. Modelling, teachers' views on the nature of modelling, and implications for the education of modellers. International Journal of Science Education, v. 24, n. 4, p. 369-387, 2002/04/01 2002. ISSN 0950-0693. Disponível em: < http://dx.doi.org/10.1080/09500690110110142 >. Acesso em: 2014/07/11.

KIND, V. Beyond Appearances: Students' misconceptions about basic chemical ideas. Royal Society Chemistry, 2004. Disponível em: < http://www.rsc.org/images/Misconceptions update tcm18-188603.pdf $>$.

MENDONÇA, P. C. C. Influência de atividades de modelagem na qualidade dos argumentos de estudantes de Química do Ensino Médio. 2011. 272. (Doutorado em Educação). Faculdade de Educação, Universidade Federal de Minas Gerais, Belo Horizonte-MG.

MORRISON, M.; MORGAN, M. S. Models as mediating instruments. In: MORGAN, M. S. e MORRISON, M. (Ed.). Models as mediators. Cambridge: Cambridge University Press, 1999. p.10-37.

MORTIMER, E. F. Concepções atomistas dos estudantes. Química Nova na Escola, 18/05/2015 1995. Disponível em: < http://qnesc.sbq.org.br/online/qnesc01/aluno.pdf $>$.

MORTIMER, E. F.; MACHADO, A. H.; ROMANELLI, L. I. A proposta curricular de química do Estado de Minas Gerais: fundamentos e pressupostos. Química Nova, v. 23, p. 273-283, 2000. ISSN 0100-4042. Disponível em: < http://www.scielo.br/scielo.php?script=sci arttext\&pid=S0100$40422000000200022 \&$ nrm=iso $>$. 
NOVICK, S.; NUSSBAUM, J. Junior high school pupils' understanding of the particulate nature of matter: An interview study. Science Education, v. 62, n. 3, p. 273-281, 1978. ISSN 1098-237X. Disponível em: < http://dx.doi.org/10.1002/sce.3730620303 >.

PEREIRA, C. L. N. A História da Ciência e a Experimentação no Ensino de Química Orgânica. 2008. 194 (Dissertação de Mestrado em Ensino de Ciências). Decanato de Pesquisa e Pós-Graduação: Instituto de Física e Instituto de Química, Universidade de Brasília, Brasília.

ROCHA-FILHO, R. C.; TOLENTINO, M.; SILVA, R. R.; TUNES, E.; SOUSA, E. C. P. D. Ensino de conceitos em Química. III. Sobre de conceitos de substância. Química Nova, v. 11, n. 4, p. 417-419, 1988.

SANTOS, W. L. P. D. Contextualização no Ensino de Ciências por meio de Temas CTS em uma perspectiva crítica. Ciência \& Ensino, v. 1, n. especial, 2007. Disponível em: < http://prc.ifsp.edu.br/ojs/index.php/cienciaeensino/issue/view/15 >.

SCHNETZLER, R. P. Alternativas didáticas para a formação docente em Química. Coleção Didática e Prática de Ensino. DALBEN, A. D., J; LEAL, L. E SANTOS, L. Belo Horizonte: Autêntica. 1: 149-166 p. 2010.

Resumo das principais ideias apresentadas e discutidas no curso sobre: Metodologias e Modelos no ensino de Química de 2 grau. São Paulo: 4은 Encontro Nacional de Ensino de Química 1988.

SÉRÉ, M. G. Children's conceptions of the gaseous state, prior to teaching. European Journal of Science Education, v. 8, n. 4, p. 413-425, 1986/10/01 1986. ISSN 0140-5284. Disponível em: < http://dx.doi.org/10.1080/0140528860080408 >. Acesso em: 2015/05/01.

SILVA, L. H. A. S.; ZANON, L. B. A Experimentação no Ensino de Ciências. In: SCHNETZLER, R. P. e ARAGÃO, R. M. R. (Ed.). Ensino de Ciências:

fundamentos e abordagens. Campinas: R. Vieira, v.1, 2000. p.120-153.

SILVA, R. R.; MACHADO, P. F. L.; TUNES, E. Experimentar Sem Medo de Errar. Ensino de Química em Foco. SANTOS, W. L. P. D. e MALDANER, O. A. Injuí: Injuí: 231-261 p. 2011.

SILVA, R. R. D.; ROCHA-FILHO, R. C.; TUNES, E.; TOLENTINO, M. Ensino de conceitos em Química. II. Matéria: um sistema conceitual quanto à sua forma de apresentação. Ciência e Cultura, v. 38, n. 12, p. 2028-2030, 1986.

STAVY, R. Children's conception of gas. International Journal of Science Education, v. 10, n. 5, p. 553-560, 1988/10/01 1988. ISSN 0950-0693. Disponível em: < http://dx.doi.org/10.1080/0950069880100508 >. Acesso em: 2015/05/01.

TERCI, C.; SILVA, R. R.; TUNES, E.; BARTHOLO, R. O Futuro do Ensino de Química - entre a Ciência e a Ficção. In: MÓL, G. S. M. (Ed.). Ensino de Química: Visões e Reflexões. ljuí: ljuí, 2012. cap. 7, p.147-166. 
TOLENTINO, M.; ROCHA-FILHO, R. C.; SILVA, R. R. A atmosfera terrestre. São Paulo: Moderna, 2004.

TOLENTINO, M.; SILVA, R. R. S.; ROCHA-FILHO, R. C.; TUNES, E. Ensino de conceitos em Química. I. Matéria: Exemplo de um sistema de conceitos científicos. Ciência e Cultura, v. 38, n. 10, p. 1721-1724, 1986.

TUNES, E. Os conceitos científicos e o desenvolvimento do pensamento verbal. In: CEDES (Ed.). Caderno CEDES - Implicações Pedagógicas do Modelo Histórico Cultural. São Paulo, v.35, 1995. p.29-39.

TUNES, E.; CARNEIRO, M. H. S.; POLONIA, A. C.; SILVA, A. A.; SILVA, M. S.; BRANDÃO, S. A. Desenvolvimento e Aprendizagem. In: (Ed.). Curso de Pedagogia para professores em exercício no início de escolarização - PIE: Eixo integrador : Escola como Instituição Social. Brasília: Faculdade de Educação - UnB, v.Módulo IV, 2002. p.222.

TUNES, E.; TOLENTINO, M.; SILVA, R. R.; SOUSA, E. C. P. D.; ROCHA-FILHO, R. C. Ensino de conceitos em Química. IV. Sobre a estrutura elementar da matéria. Química Nova, v. 12, n. 2, p. 199-202, 1989.

VOGELEZANG, M. J. Development of the concept 'chemical substance' - some thoughts and arguments. International Journal of Science Education, v. 9, n. 5, p. 519-528, 1987/10/01 1987. ISSN 0950-0693. Disponível em: < http://dx.doi.org/10.1080/0950069870090502 >. Acesso em: 2015/05/08.

VYGOTSKY, L. S. A construção do pensamento e da linguagem. São Paulo: Martins Fontes, 2001. 
Apêndice A - Proposta de Ação Profissional "O estudo de gases: Uma estratégia de ensino dos três níveis do conhecimento químico utilizando sistemas conceituais e modelos e modelagem" 



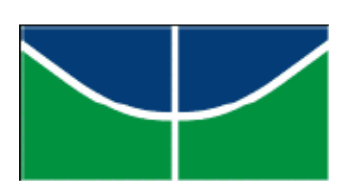

\section{UNIVERSIDADE DE BRASÍLIA}

Decanato de Pesquisa e Pós-Graduação

Instituto de Ciências Biológicas

Instituto de Física

Instituto de Química

Faculdade UnB Planaltina

Programa de Pós-Graduação em Ensino de Ciências

Mestrado Profissional em Ensino de CiênCias

\section{$O$ estudo de gases: \\ Uma estratégia de ensino dos três níveis do conhecimento químico utilizando sistemas conceituais e modelos e modelagem}

Mayara Soares de Melo

Proposta de ação profissional resultante da dissertação realizada sob orientação do Prof. Dr. Roberto Ribeiro da Silva apresentado à banca examinadora como requisito parcial à obtenção do Título de Mestre em Ensino de Ciências pelo Programa de Pós-Graduação em Ensino de Ciências da Universidade de Brasília.

Brasília - DF 


\section{SUMÁRIO}

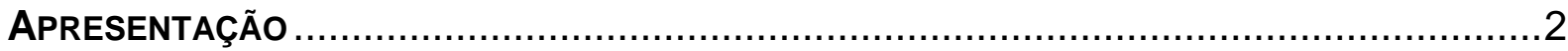

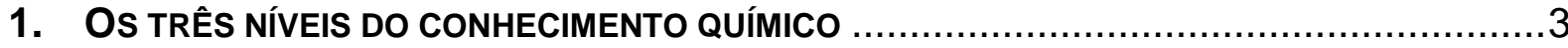

2. ATIVIDADES DEMONSTRATIVO-INVESTIGATIVAS: UMA ESTRATÉGIA PARA TRABALHAR OS TRÊS NÍVEIS DO CONHECIMENTO QUÍMICO ........................................................

3. UTILIZANDO MODELOS E MODELAGEM NO ENSINO DE QUÍMICA $\ldots \ldots \ldots \ldots \ldots \ldots \ldots \ldots \ldots \ldots \ldots$

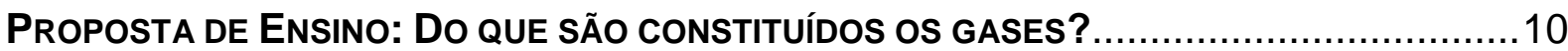

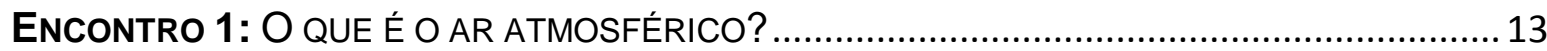

ENCONTRO 2: CONSTITUIÇÃO DAS SUBSTÂNCIAS PRESENTES NO AR ............................... 16

ENCONTRO 3: PROPRIEDADES DAS SUBSTÂNCIAS PRESENTES NO AR -

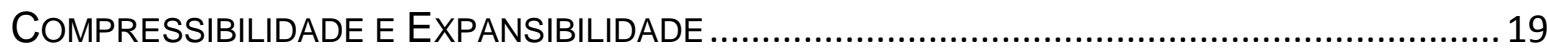

ENCONTRO 4: COMO REPRESENTAR OS CONSTITUINTES DAS SUBSTÂNCIAS UTILIZANDO A LINGUAGEM QUÍMICA? 24

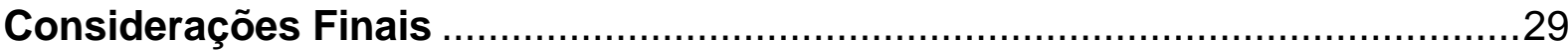

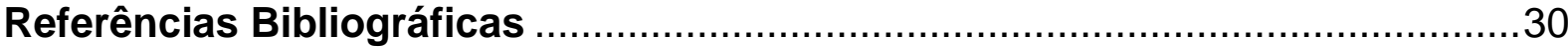




\section{APRESEnTAÇÃo}

Bem-vindo Professor (a),

Imagino que a principal motivação para você estar acessando este trabalho seja a necessidade de buscar novas estratégias que favoreçam o processo ensinoaprendizagem de conceitos químicos em suas aulas. Assim como você, diariamente tenho buscado melhorar minha prática docente com aulas diferenciadas na qual utilizo conhecimentos que adquiri durante a formação inicial e por meio de leituras em periódicos de ensino de ciências disponíveis na internet.

A partir dessas leituras, me interessei em entender melhor quais as dificuldades dos estudantes que levam ao baixo desempenho e ao crescente desinteresse pela Química, e por isso estive ao longo de dois anos em formação continuada no Mestrado em Ensino de Ciências.

Meu problema de pesquisa surgiu ao observar a dificuldade dos meus alunos em representar por meio de desenhos de esferas, os constituintes das substâncias e as equações químicas apresentadas. Percebi minha dificuldade em possibilitar que os estudantes fizessem a transição entre modelos de reações químicas (modelos de natureza atômico-molecular) para as expressões representacionais para os respectivos modelos.

A partir da pesquisa, observamos que ao situar os conceitos ensinados em sistemas conceituais, além de abordá-los utilizando experimentos com o qual sejam discutidos os três níveis do conhecimento químico (macroscópico, submicroscópico e representacional), a compreensão desses conceitos científicos pode ser facilitada.

Mas o que são esses sistemas conceituais? E os três níveis do conhecimento químico? Como podemos ensinar conceitos químicos nessa perspectiva? Para responder a essas perguntas e ajuda-lo a utilizar essas ideias em suas aulas foi elaborado esse material.

Desta forma, inicialmente é explicado o que são os sistemas conceituais, os três níveis do conhecimento químico e como possibilitar a transição entre cada um desses níveis usando atividades demonstrativo-investigativas e modelos e modelagens. Ao final desse módulo, é apresentada uma proposta que você pode desenvolver em suas aulas de Química. 


\section{OS TRÊS NÍVEIS DO CONHECIMENTO QUÍMICO}

Quando observamos um químico falando sobre seu trabalho e suas pesquisas, podemos perceber que ele fala dos materiais e substâncias que utiliza, das reações e processos por ele conduzidos e quais são seus objetivos. Nesse diálogo, o pesquisador aborda aspectos macroscópicos e explicações de natureza atômicomolecular, simultaneamente, transitando em diferentes formas de representar os aspectos do conhecimento químico em uma espécie de ginástica mental.

Pensando nisso, Johnstone (1982) foi um dos primeiros autores a propor um modelo que explicasse esses diferentes níveis de representação. Ao longo dos anos, esses níveis passaram por modificações, sendo adaptados e reorganizados, e tendo sido utilizados em pesquisas realizadas em vários países. Atualmente esses níveis são definidos por Johnstone (2009) como:

Macro/tangível: parte "observável" por meio dos sentidos e mensurável da Química que pode ser descrita por meio de suas propriedades: cor, odor, densidade, efervescência, etc.;

> Molecular/invisível: se refere a como os fenômenos e propriedades observados no primeiro nível são explicados pela Ciência, utilizando conceitos abstratos, tais como: átomos, íons, moléculas, ligações química, de modo a fornecer um modelo para se racionalizar e entender esses fenômenos;

Simbólico/matemático: forma utilizada pelos químicos para se representar as substâncias e transformações por meio de símbolos e equações convencionados pela comunidade científica.

Nesta proposta, utilizaremos uma nomenclatura diferente para cada um desses níveis, com a qual estamos mais habituados. O nível macro/tangível é chamado de macroscópico (ou macro), o molecular/invisível é denominado submicroscópico ${ }^{16}$ (ou submicro) e o simbólico/matemático é, para nós, o representacional. Tal como Johnstone $(2006,2009)$, esses níveis foram organizados em um triângulo (Fig. 1):

\footnotetext{
${ }^{16}$ Optamos por utilizar o termo submicro conforme as sugestões de Gilbert e Treagust (2009), que acreditam que a utilização do termo micro ou microscópico pode possibilitar que os estudantes acreditem que é possível observar esse nível utilizando equipamentos (microscópios opticos).
} 
Figura 1 - Níveis de representação do conhecimento químico

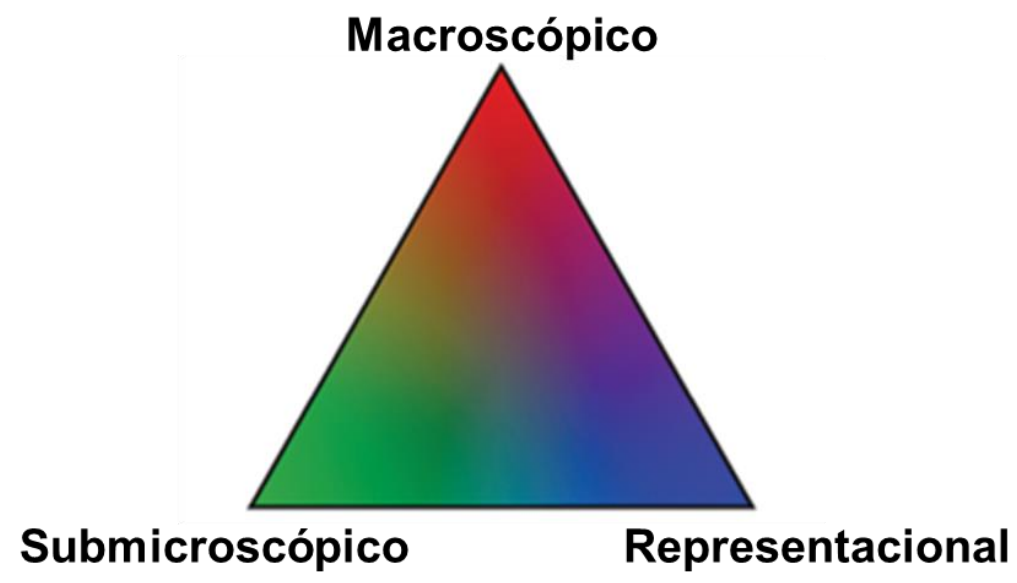

Fonte: Adaptado de Johnstone (2009, p. 24)

Uma das dificuldades para compreensão de conceitos químicos é resultante da forma como estes são discutidos por professores. Conforme dito anteriormente, um professor que tem sua formação em Química consegue transitar nesses níveis facilmente, explicando os conhecimentos utilizando os três de forma simultânea. Com isso, muitos estudantes não conseguem acompanhar esse raciocínio tendo seu aprendizado comprometido.

Desta forma, sugerimos que inicialmente seja trabalhado o nível macroscópico, a partir de fenômenos mais familiares e interessantes para os alunos, e a partir dele serem introduzidos conhecimentos de nível submicroscópicos e representacionais. Uma das formas de se trabalhar esses três níveis nas aulas de química é desenvolvendo atividades demonstrativo-investigativas, e por isso, são melhor explicadas no próximo tópico. 


\section{ATIVIDADES DEMONSTRATIVO-INVESTIGATIVAS: UMA ESTRATÉGIA PARA TRABALHAR OS TRÊS NÍVEIS DO CONHECIMENTO QUÍMICO}

A experimentação é uma atividade que tem sido bastante recomendada no ensino de Ciências. Diversos documentos oficiais, tais como os Parâmetros Curriculares Nacionais (PCN), Orientações Complementares aos Parâmetros Curriculares Nacionais ( $\mathrm{PCN}+$ ), entre outros, sugerem a utilização dela na perspectiva de possibilitar a articulação entre fenômeno e teoria e de se promover um ensino mais contextualizado e interdisciplinar.

Porém, muitos professores têm uma visão simplista e equivocada da experimentação no ensino, acreditando que essas atividades só possam ser realizadas em laboratórios bem equipados; que os experimentos devem ser realizados para que se comprove a teoria na prática; e que há pouco tempo para execução dessas atividades durante as aulas.

De forma diferente, entendemos que as atividades experimentais podem ser realizadas em diversos locais, tais como: em hortas; em visitas planejadas; no laboratório da escola; ou mesmo na sala de aula, utilizando vídeos, simulações computacionais, atividades demonstrativoinvestigativas (SILVA, MACHADO, TUNES, A experimentação não pode ser reduzida a atividades realizadas em laboratórios!

Elas podem ocorrer na própria sala de aula, em estabelecimentos comerciais, em espaços públicos... 2011).

Essas atividades não devem ser entendidas como sendo uma forma de se "provar a teoria" ou "observar a teoria na prática". Essas formas equivocadas de abordagem são reflexo do entendimento de algumas pessoas quanto a natureza da ciência: entendendo o conhecimento científico como algo que está no ambiente pronto para ser descoberto.

É preciso que a atividade experimental seja entendida não como uma forma de provar se uma teoria é verdadeira, mas sim de testar a capacidade de generalização e previsão dela. É essa característica que dá a experimentação um

A capacidade de generalização de uma teoria diz respeito a sua potencialidade em explicar fenômenos comparáveis... Já a de previsão é a potencial capacidade de prever fenômenos ainda não observados... 
caráter investigativo. Sendo realizadas nessa perspectiva, as atividades experimentais permitem que os conhecimentos científicos sejam entendidos como construção humana, como verdades transitórias.

Dentre esse leque de possibilidades para 0 desenvolvimento da experimentação em aulas de Química, as atividades demonstrativo-investigativas podem ser bastante proveitosas. Nessas atividades, o professor apresenta e discute experimentos simples na própria sala de aula, e a partir deles introduz conceitos teóricos referentes aos fenômenos observados.

Para condução de experimentos demonstrativo-investigativos, são recomendadas as seguintes etapas:

> Pergunta Inicial: É formulada uma questão que desperte a curiosidade dos estudantes. No início da atividade, o professor faz a pergunta e ouve as diversas respostas dos estudantes, conhecendo suas concepções prévias e estimulando uma maior participação e interesse.

$>$ Discussão dos três níveis do conhecimento químico:

Observações macroscópicas: Após a pergunta inicial, o professor realiza a atividade experimental explicando cada procedimento que está sendo executado. A observação macroscópica é a descrição do que foi possível ser visualizado durante o experimento.

Interpretações submicroscópicas: Depois das observações macroscópicas, é explicitada a teoria científica utilizada para explicar o fenômeno em questão. São utilizados diversos conceitos como os de átomos, íons, moléculas.

Expressão representacional: É apresentada uma representação das transformações observadas utilizando a linguagem científica. Podem ser utilizadas equações químicas, gráficos, etc.

- Fechamento da aula: É respondida à pergunta apresentada no início da atividade. Também é recomendado que seja trabalhada a interface CTS (Ciência-Tecnologia-Sociedade) que seriam as implicações sociais, ambientais, tecnológicas, relacionadas a atividade desenvolvida.

As atividades demonstrativo-investigativas são bastante utilizadas em minha prática docente. Desta forma, ao longo dessas discussões percebi que os estudantes apresentavam dificuldade em escrever as expressões representacionais (equações 
químicas) a partir de modelos de natureza atômico-molecular. Visando possibilitar uma melhor compreensão, durante essas atividades foram utilizados modelos e modelagem e sistemas conceituais, estratégias que serão apresentadas a seguir.

\section{UTILIZANDO MODELOS E MODELAGEM NO ENSINO DE QUímICA}

Ao pensarmos nos níveis de representação do conhecimento químico, mais especificamente no nível representacional que se refere as teorias de natureza atômico-molecular utilizadas para explicar os fenômenos observados, percebe-se a importância dos modelos para a Química.

Mas o que são modelos? Estudos apontam que muitos docentes não sabem responder a essa questão ou tem uma compreensão equivocada da significação de modelos, entendendo estes como "cópias" ou

Modelos são construções humanas usadas para representar parcialmente uma entidade tendo objetivo(s) definido(s) e limitações.

Não são cópias nem reprodução da realidade! "reproduções" da realidade (JUSTI, GILBERT, 2003). Dentre as diversas definições para modelos, utilizamos nessa proposta a apresentada por Justi (2011): "um modelo é uma representação parcial de uma entidade, elaborado com um, ou mais objetivo(s) específico(s) e que pode ser modificado". Desta forma, um modelo é uma construção da mente humana que pode representar parcialmente um objeto, um processo, uma ideia, etc. e não deve ser entendido como a realidade e nem uma cópia dela.

Os modelos podem ser utilizados com diferentes objetivos, dentre os quais destacam-se:

* Possibilitar que entidades abstratas sejam visualizadas, favorecendo a interpretação de dados experimentais e, consequentemente o desenvolvimento de explicações científicas para esses dados (JUSTI, GILBERT, 2002);

* A partir de representações simplificadas, facilitar o entendimento de fenômenos mais complexos (JUSTI, 2011);

* "Favorecer a comunicação de ideias" (JUSTI, 2011, p. 212); 
* Facilitar a abstração de entidades que até o momento são impossíveis de serem visualizadas;

Dependendo da finalidade de cada modelo, após ser elaborado mentalmente é necessário que eles sejam expressos de alguma maneira para que possam ser acessados. Dentre as formas de representação dos modelos, podemos citar o: modo concreto, quando são utilizados materiais para produzir uma representação tridimensional; verbal, quando são explicadas as características de um modelo usando a forma falada ou escrita; matemático: quando são utilizadas expressões matemáticas, dentre outros.

Por serem amplamente utilizados no desenvolvimento do conhecimento químico, é essencial que tanto os professores quanto os estudantes de Ciências compreendam a importância dos modelos, como eles são construídos, suas finalidades e também limitações. Assim, no ensino de Química, é importante que o docente oportunize que os estudantes aprendam por meio de estratégias que envolvam modelos e modelagem.

Segundo Justi (2011) e, Justi e Gilbert (2002), existem algumas etapas inerentes as atividades de modelagem que são:

* a elaboração: são definidos os objetivos do modelo, tem-se experiências com a entidade modelada e são selecionados os aspectos da realidade que serão utilizados na descrição da entidade;

* a expressão: é decidida a forma mais adequada de representação do modelo imaginado, se é de forma concreta, simbólica, dentre outras;

* o teste: são realizados experimentos mentais ou empíricos (ou ambos) com o modelo e é observado se este possui falhas que devem resultar em modificações ou se estas são graves levando a rejeição desse modelo.

* a identificação de abrangências e limitações: nessa etapa são avaliados os modelos que conseguiram atingir os objetivos estabelecidos nas etapas anteriores, sendo discutidas as abrangências e limitações dos modelos propostos.

No desenvolvimento dessas atividades, é importante que cada uma dessas etapas seja discutida ao serem desenvolvidas essas atividades em sala de aula.

Neste módulo, a partir de diagramas propostos por Justi e Gilbert (2002) e sintetizado por Justi (2011), organizamos as etapas envolvidas nas atividades de 
modelagem propostas nesse módulo no esquema apresentado na Figura 2. Durante a descrição das atividades, cada uma dessas etapas deverá ser trabalhada com os estudantes.

Figura 2 - Etapas envolvidas nas atividades de modelagem

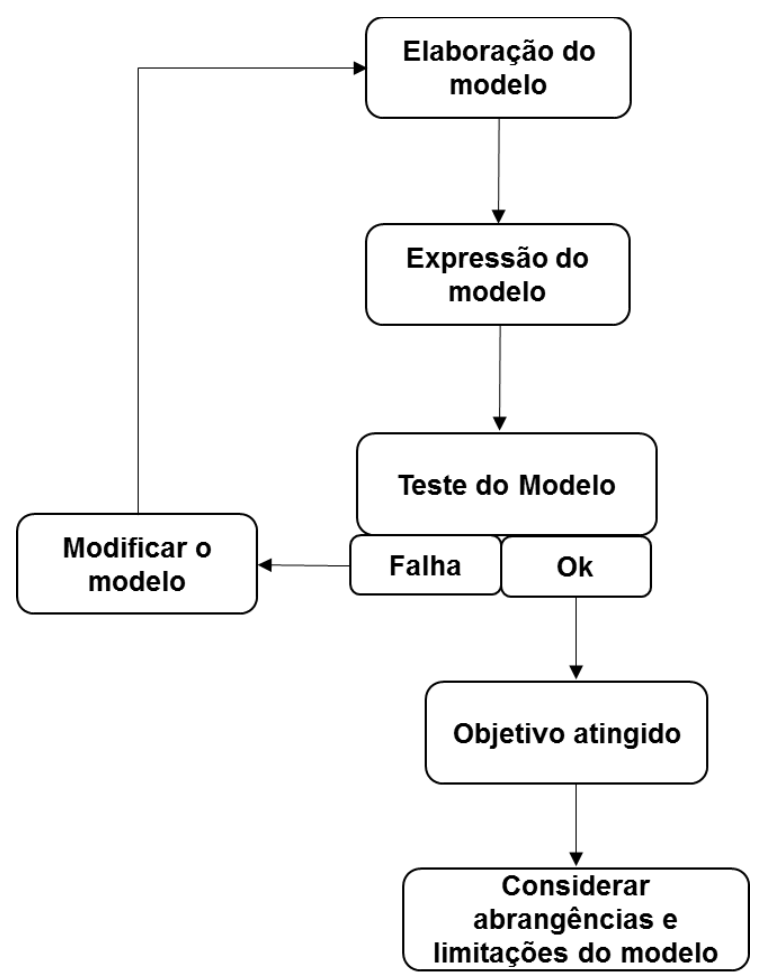

Fonte: Adaptado de Justi e Gilbert (2002) apud Mendonça (2011, p. 27) 


\section{Proposta de Ensino: Do que são constituídos os GASes?}

Pensando na importância de serem desenvolvidas propostas que favoreçam o processo ensino-aprendizagem de conceitos químicos, sendo considerados os três níveis de representação desses conhecimentos (macroscópico, submicroscópico e representacional) é apresentada essa proposta.

Para discussão dos três níveis, sugerimos a utilização de atividades demonstrativo-investigativas e de atividades envolvendo modelos e modelagem.

Recomendamos ainda que os conceitos científicos sejam trabalhados segundo as ideias de Vygotsky (2001), sendo discutidos dentro de sistemas conceituais. Para Vygotsky (2001), existem pelo menos duas classes do pensamento verbal ${ }^{17}$ que são os conceitos cotidianos e os conceitos científicos.

O pensamento por conceitos cotidianos se desenvolve na interação social tendo como principal característica ter as palavras sendo relacionadas diretamente ao objeto. Por exemplo, durante uma aula o professor pergunta a um estudante o que é o ar, e ele

No pensamento por conceitos cotidianos, a palavra é relacionada diretamente ao objeto...

No pensamento por conceitos científicos, um conceito é mediado por outro conceito... responde que o ar é o vento. No conceito apresentado por esse aluno, a palavra é relacionada diretamente ao objeto. Já os conceitos científicos, normalmente desenvolvidos na instrução formal, se caracterizam por serem organizados em um sistema de inter-relações, tendo um conceito mediado por outro conceito. Assim, na escola os estudantes desenvolvem uma outra forma de pensar, se apropriando de regras lógicas que permitem ligar um significado a outro (TUNES, CARNEIRO, POLONIA, SILVA, SILVA, BRANDÃO, 2002).

No caso do exemplo citado anteriormente, é importante que o professor possibilite que esse estudante também possa operar seu pensamento por meio de conceitos científicos. Para isso, esse significado deve ser discutido dentro de um sistema hierárquico segundo sua abrangência - dos mais abrangentes

\footnotetext{
17 Para Vygotsky (2001), o pensamento verbal é o modo de pensar tipicamente humano, sendo este o único ser vivo capaz de estabelecer relações entre fatos e fenômenos por intermédio da palavra, sem a necessidade de ser atingido diretamente pelos sentidos.
} 
(supraordenados) para os subjacentes (subordinados) - tendo relações de subordinação bem definidas e conceitos de mesmo nível mutuamente excludentes entre si. O sistema conceitual (Fig. 3) apresentado a seguir tem essas características.

Esse sistema conceitual foi organizado a partir de dois outros sistemas apresentados por Tolentino et al. (1986), que definiram a primeira parte chamada de "forma de apresentação da matéria" referida na figura acima como mundo macroscópico, e por Rocha-Filho et al. (1988) que definiram a segunda, que foi chamada de "natureza da matéria" correspondendo ao mundo submicroscópico apresentado acima.

Figura 3 - O sistema conceitual de matéria

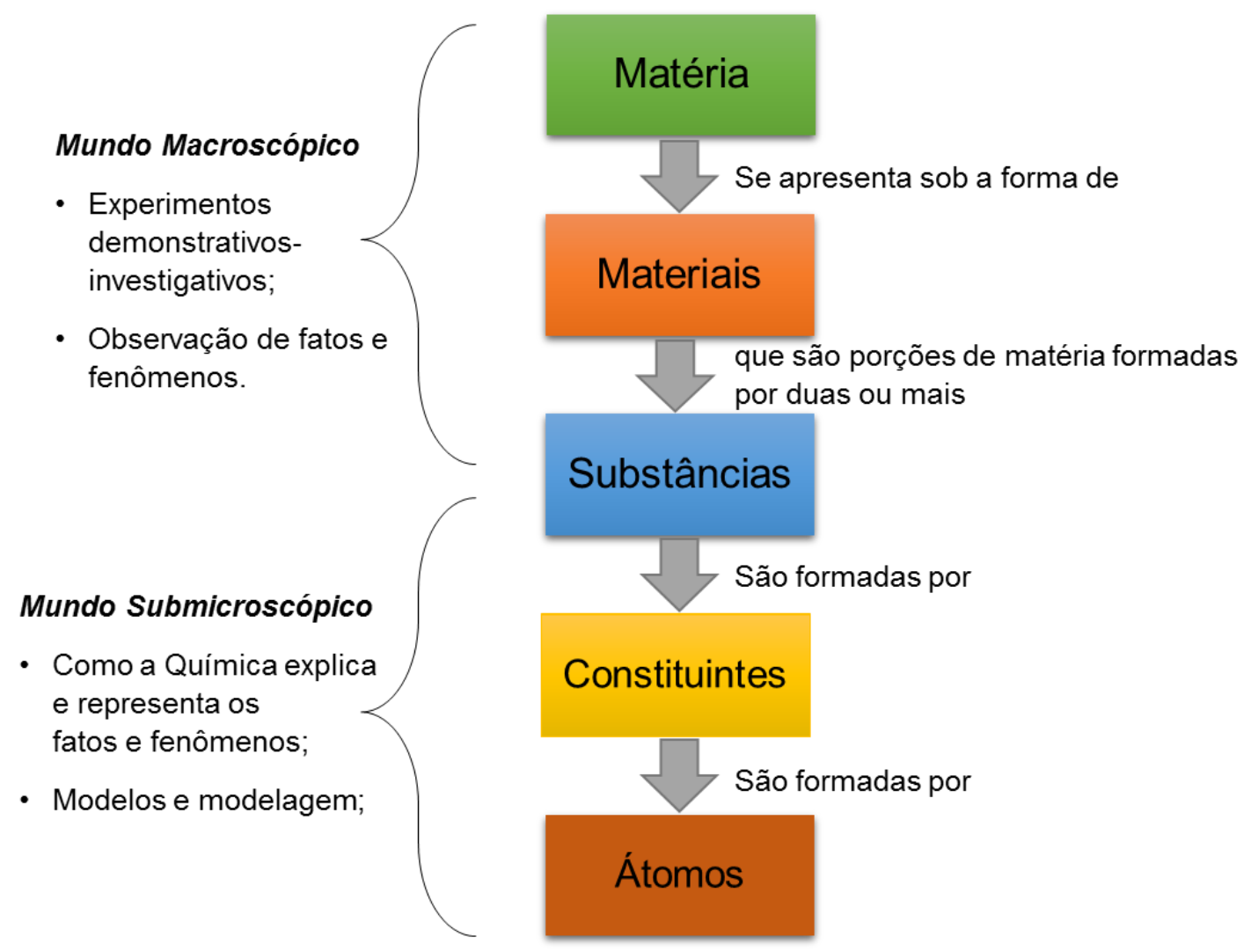

Fonte: Adaptado de Tolentino et al. (1986) e Rocha-Filho et al. (1988)

Para cada um dos conceitos apresentados nos sistemas propostos por Tolentino et al. (1986) e Rocha-Filho et al. (1988) foi proposto um enunciado:

* Matéria: Tudo que ocupa um lugar no universo;

* Material: Porção de matéria formada por duas ou mais substância;

* Substância: Porção de matéria formada por apenas um tipo de constituinte; 
* Constituinte: Conjunto de átomos que caracteriza uma substância (ROCHAFILHO, et al., 1988, p. 418)

Nota-se que em todos os enunciados os conceitos são relacionados a um outro conceito, sendo obedecidas relações lógicas de subordinação. Outros sistemas conceituais são apresentados em Tunes et al. (1986) e Silva et al. (1986).

Voltando ao exemplo anterior, em que um professor pergunta a um estudante sobre o conceito de ar, entendendo os conceitos científicos como participantes de um sistema conceitual, essa questão poderia ser respondida entendendo o ar como um material, por ele ter mais de uma substância. Nessa proposta, durante o desenvolvimento das atividades demonstrativo-investigativas, os conceitos são discutidos a partir do sistema conceitual.

Desta forma, a presente proposta foi elaborada tendo como objetivo favorecer que você, professor, discuta com seus estudantes os três níveis do conhecimento químico (macro, submicro e representacional) por meio de atividades demonstrativoinvestigativas que são discutidas utilizando sistemas conceituais e modelos e modelagem.

Pensando na dificuldade vivenciada pelos estudantes na apropriação das diferentes formas de representação dos constituintes das substâncias, escolhemos o tema atmosfera para o desenvolvimento dessas estratégias, pois:

$>$ o desenvolvimento das primeiras teorias científicas sobre a natureza particulada da matéria se deram a partir de experimentos envolvendo gases;

> os constituintes das substâncias presentes no ar são formados por um número reduzido de átomos, sendo mais simples de serem representados utilizando modelos concretos e matemáticos;

A partir dessas ideias, organizamos esse módulo didático com sugestões para quatro encontros, que sugerimos serem compostos de duas aulas cada (com duração de aproximadamente $1 \mathrm{~h}$ e $30 \mathrm{~min}$ ). Os planos de aulas para cada um desses encontros são apresentados a seguir. 
Encontro 1: O que é o ar atmosférico?

\section{Objetivos:}

$\checkmark$ Utilizar o sistema conceitual Forma de Apresentação da Matéria para realizar a classificação do ar como sendo um material;

$\checkmark$ Utilizar o sistema conceitual Natureza da Matéria para classificar os gases presentes no ar tais como: o nitrogênio, o oxigênio e o hidrogênio, como substâncias;

$\checkmark$ Representar por meio de modelos concretos os átomos que formam os constituintes das substâncias nitrogênio, o oxigênio e o hidrogênio, a partir do modelo de Dalton.

\section{Estratégias didáticas:}

Nessa aula deverá ser introduzido o tema que será trabalhado ao longo dessa unidade. Assim, sugerimos que essa aula tenha início com a pergunta: "O que é atmosfera terrestre?". Os estudantes devem anotar a questão proposta no caderno e responde-la. Após todos terem respondido, o professor deve pedir que alguns estudantes leiam suas respostas para toda turma.

A partir dessa conversa, deve ser explicado

Quando perguntar, ouça! É importante ouvir as respostas dos estudantes e dialogar a respeito delas! aos estudantes que a atmosfera terrestre é a camada de gases que envolve a Terra, e que essa camada é formada por vários gases. Os gases presentes na atmosfera terrestre deverão ser apresentados em uma tabela como a apresentada a seguir. Esta poderá ser impressa e afixada na parede, caso a aula ocorra em uma sala ambiente, ser apresentada na forma de slide ou mesmo escrita no quadro previamente para que possa ser observada pelos alunos.

Para as observações macroscópicas, sugerimos que antes da aula o professor construa um cubo semelhante ao da imagem abaixo. A linha preta foi amarrada para separar o espaço (volume) que é ocupado pelo gás nitrogênio, a vermelha para o gás 
oxigênio e entre as linhas vermelha e preta correspondendo ao volume ocupado por todos os outros gases.

Figura 4 - Cubo usado para representar as quantidades dos diferentes gases presentes no ar

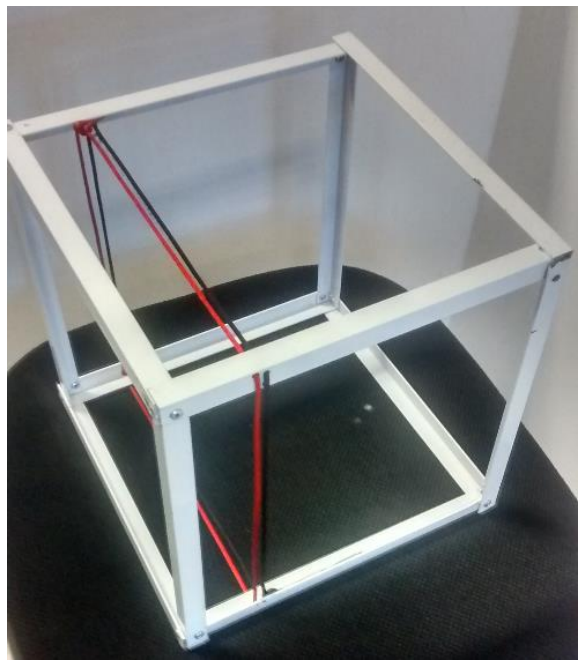

Quando utilizar o cubo para discutir as proporções dos gases, tome cuidado para os estudantes não pensarem que as substâncias estão separadas na atmosfera! Procure destacar que as substâncias estão misturadas no ar!

Pode ser citado, por exemplo, que os seres vivos respiram o ar e dentre as substâncias presentes no ar está a substância oxigênio!

Fonte: do autor

Assim, o cubo deve ser mostrado aos estudantes indicando as partes referentes a cada gás a partir da leitura dos dados apresentados na Tabela 1. É importante deixar claro que esses gases não se encontram separados, mas sim formando uma mistura de gases.

Tabela 1 - Composição do ar limpo e seco

\begin{tabular}{|c|c|}
\hline \multicolumn{2}{|c|}{ Composição do ar limpo e seco (homosfera) } \\
\hline Componente & Teor (por metro cúbico) \\
\hline gás nitrogênio & 780,8 litros \\
\hline gás oxigênio & 209,5 litros \\
\hline argônio & 9,3 litros \\
\hline gás carbônico & $\approx 375$ mililitros \\
\hline neônio & 18 mililitros \\
\hline hélio & 5,2 mililitros \\
\hline metano & 1,8 mililitros \\
\hline criptônio & 1,1 mililitros \\
\hline gás hidrogênio & 0,53 mililitro \\
\hline xenônio & 0,086 mililitro \\
\hline
\end{tabular}

Fonte: Tolentino, Rocha-Filho, Silva (2004), p.16 
Deve ser explicado que o ar é um material pois é formado por mais de uma substância, conforme pode ser observado na Tabela 1. Essa explicação deve ser feita utilizando a primeira parte do sistema conceitual (Fig. 3). Como ele será bastante utilizado é importante que esteja sempre visível para que os estudantes possam utiliza-lo. De preferência, imprima um cartaz, ou desenhe em cartolina e afixe em alguma parede da sala.

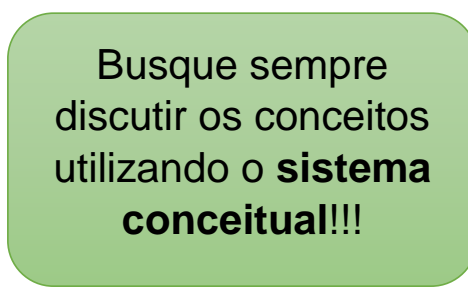

Peça que os estudantes respondam novamente à questão proposta no início da aula utilizando as ideias discutidas utilizando o sistema conceitual.

No segundo momento da aula deverá ser discutida a segunda parte do sistema conceitual - "natureza da matéria". Para isso, sugerimos que os estudantes sejam questionados sobre a constituição dos gases presentes no ar. Isso deve ser feito sempre retomando o sistema conceitual, podendo ser realizada a seguinte pergunta: "Vimos que o ar é um material formado por várias substâncias, tais como o gás oxigênio, o gás nitrogênio e o gás hidrogênio... $E$ do que são formadas essas substâncias?".

Peça que os estudantes formem grupos (4 ou 5 pessoas) para que discutam essa questão e formulem uma resposta na qual seja proposta uma ideia para constituição das substâncias. Eles devem anotá-las em seus cadernos. Quando todos grupos terminarem a atividade, um estudante de cada grupo deverá compartilhar a resposta com toda a turma, até que todos sejam ouvidos.

Após essa discussão deverá ser explicado que, assim como os estudantes, várias pessoas tentaram responder a essa pergunta e uma delas foi John Dalton em 1805 , que elaborou um modelo que tinha como objetivo responder a essa questão. Devem ser explicadas as principais ideias de Dalton utilizando o sistema conceitual: as substâncias seriam formadas por partículas esféricas e não divisíveis chamadas de átomos; os diferentes átomos das diferentes substâncias teriam massas diferentes.

A partir dessas ideias, os estudantes deverão representar utilizando massinhas de modelar os átomos que constituem o gás oxigênio, o gás hidrogênio e 0 gás nitrogênio, segundo as ideias de Dalton. É importante observar os modelos representados pelos estudantes e dialogar com eles a respeito de modo a conhecer suas concepções. 
Encontro 2: Constituição das substâncias presentes no ar

\section{Objetivos:}

$\checkmark$ Representar por meio de modelos concretos as moléculas que constituem as substâncias nitrogênio, o oxigênio e o hidrogênio, a partir do modelo de Dalton modificado.

\section{Estratégias didáticas:}

A aula deve ser iniciada retomando as ideias discutidas na aula anterior. Para possibilitar uma maior participação dos estudantes e perceber possíveis mudanças conceituais, podem ser feitas as seguintes questões: "O que é a atmosfera terrestre?", "O que é o ar?", "Do que os gases presentes no ar são constituídos?".

Em seguida, sugerimos que sejam revisadas as ideias de Dalton sobre a constituição das substâncias. Novamente, devem ser entregues massinhas de modelar de duas cores diferentes aos estudantes, e pedir que eles representem os átomos presentes nas substâncias oxigênio e nitrogênio.

Quando terminarem, deve ser explicado que, segundo Dalton, em uma reação química ocorre a combinação de átomos, exemplificando a reação de formação do monóxido de nitrogênio, que seria resultante da combinação entre um átomo de oxigênio e um átomo de nitrogênio. Os estudantes deverão representar também o monóxido de nitrogênio, a partir da união entre o átomo de oxigênio e o de nitrogênio modelados anteriormente, dando ênfase no entendimento que um átomo de oxigênio reagindo com um átomo de nitrogênio resulta em um monóxido de nitrogênio, chamado por Dalton de átomo composto. Assim, um volume de nitrogênio ( $\mathrm{n}$ átomos) reage com 1 volume de oxigênio ( $\mathrm{n}$ átomos), formando um volume de monóxido de nitrogênio ( $\mathrm{n}$ átomos compostos).

A partir da discussão desse modelo, deve ser explicado que um cientista chamado de Gay-Lussac, a partir de estudos experimentais envolvendo reações químicas entre diferentes gases, observou uma incoerência no modelo de Dalton. 
Durante a reação química envolvendo os gases oxigênio e nitrogênio, em uma relação de um para um, tal como modelado pelos estudantes, era obtido o dobro de monóxido de nitrogênio. Ou seja, um volume de oxigênio reage com um volume de nitrogênio e produz dois volumes de monóxido de nitrogênio.
O modelo de Dalton é falho ao ser usado para explicar os experimentos de Gay-Lussac.

Para Dalton, os dados experimentais de Gay-Lussac estavam errados. Para GayLussac, o átomo deveria ser divisível

Sugerimos que a partir dessas ideias, os estudantes sejam convidados a propor possíveis soluções para esse problema. Podem ser formados grupos (4 ou 5 pessoas) para discutirem a questão e observando os modelos construídos por eles construídos tentem propor alguma mudança ao modelo utilizado que resolva essa questão. As possíveis soluções podem ser compartilhadas e discutidas com a turma, e esgotadas as ideias pode ser apresentada contribuição de Avogadro ao modelo de Dalton.

Assim, deverá ser explicado que quem propôs uma solução para a pendência entre Dalton e Gay-Lussac foi um cientista chamado Avogadro. Em sua proposta, Avogadro sugeriu que as substâncias não seriam formadas por átomos, mas sim por moléculas diatômicas (entidades formadas por dois átomos), o que chamamos de Modelo de Dalton modificado. Após ser apresentada essa ideia, cada grupo de estudantes deve representar novamente os

Avogadro introduz a noção de molécula ao modelo de Dalton, resolvendo a pendência entre Dalton e Gay-

Lussac constituintes das substâncias oxigênio e nitrogênio a partir do modelo de Dalton modificado e, em seguida, representar duas moléculas de monóxidos de nitrogênio, o que soluciona a questão.

Essas ideias são resumidas em uma animação "Do que são constituídos os gases presentes no ar?" produzida utilizando o power point e disponibilizada no site youtube pelo link: https://youtu.be/MUxx9XJpaWY. Na Figura 5 a seguir é mostrada a entrada da animação.

Ao passar o vídeo é importante que seja discutida a conservação da matéria, sendo interessante contar o número de átomos de cada substância antes e após o experimento proposto por Gay-Lussac, segundo as ideias de Dalton, e depois segundo o modelo de Dalton modificado, possibilitando que os estudantes percebam a necessidade de ter uma mesma quantidade de átomos de cada substância durante todo o processo. 
Figura 5 - Vídeo "Do que são constituídos os gases presentes no ar?"

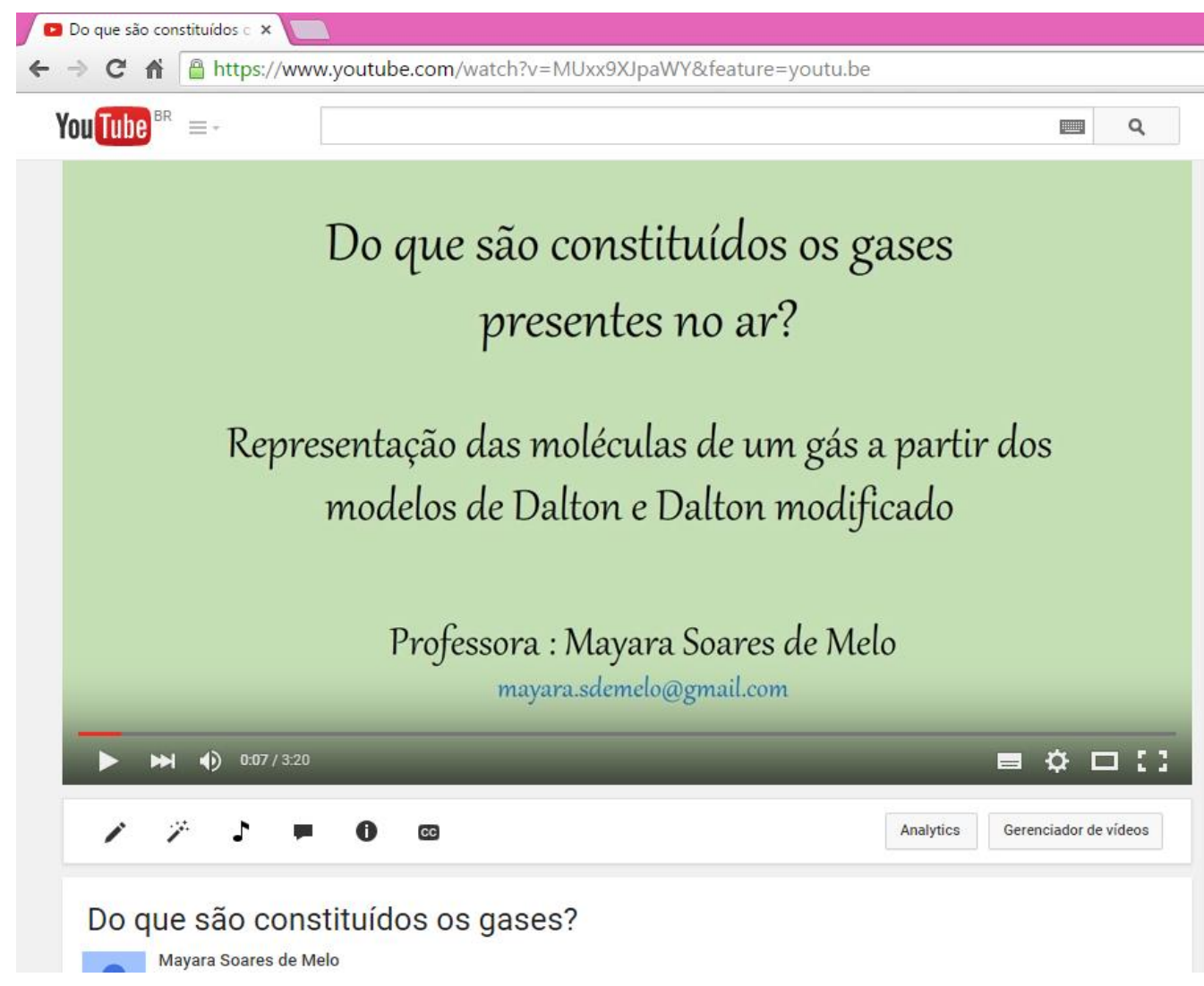

Fonte: https://youtu.be/MUxx9XJpaWY, acessado em 17/07/2015

Após a discussão do modelo de Dalton modificado, deve ser novamente utilizado o sistema conceitual, explicando que as substâncias oxigênio e nitrogênio são formadas por constituintes, nesse caso moléculas, e esses constituintes que são formados por átomos. 
Encontro 3: Propriedades das substâncias presentes no ar - Compressibilidade e Expansibilidade

\section{Objetivos:}

$\checkmark$ Representar por meio de modelos concretos as moléculas que constituem as substâncias nitrogênio, o oxigênio e o hidrogênio, a partir do modelo de Dalton modificado;

$\checkmark$ Representar os constituintes (moléculas) das substâncias mais próximas umas das outras durante a compressão, e mais distantes durante a expansão.

\section{Estratégias didáticas:}

Nessa aula serão realizadas duas atividades demonstrativo-investigativas, uma para discutir a compressão do ar e outra, a expansão.

O primeiro deles é iniciado com a seguinte pergunta: "É possível fazer o êmbolo de uma seringa se mover sozinho?". As tentativas de responder à questão proposta deverão ser ouvidas e discutidas.

Em seguida deve ser realizado o seguinte procedimento: (1) pegar uma seringa vazia e puxar o êmbolo, enchendo-a de ar; (2) colocar o dedo embaixo da seringa impedindo a saída do ar e pressionar o êmbolo com a outra mão sem tirar o dedo que está vedando a ponta; (3) tirar a mão do êmbolo (Figura 6).

Figura 6 - Procedimentos a serem realizadas demonstrativamente com a seringa
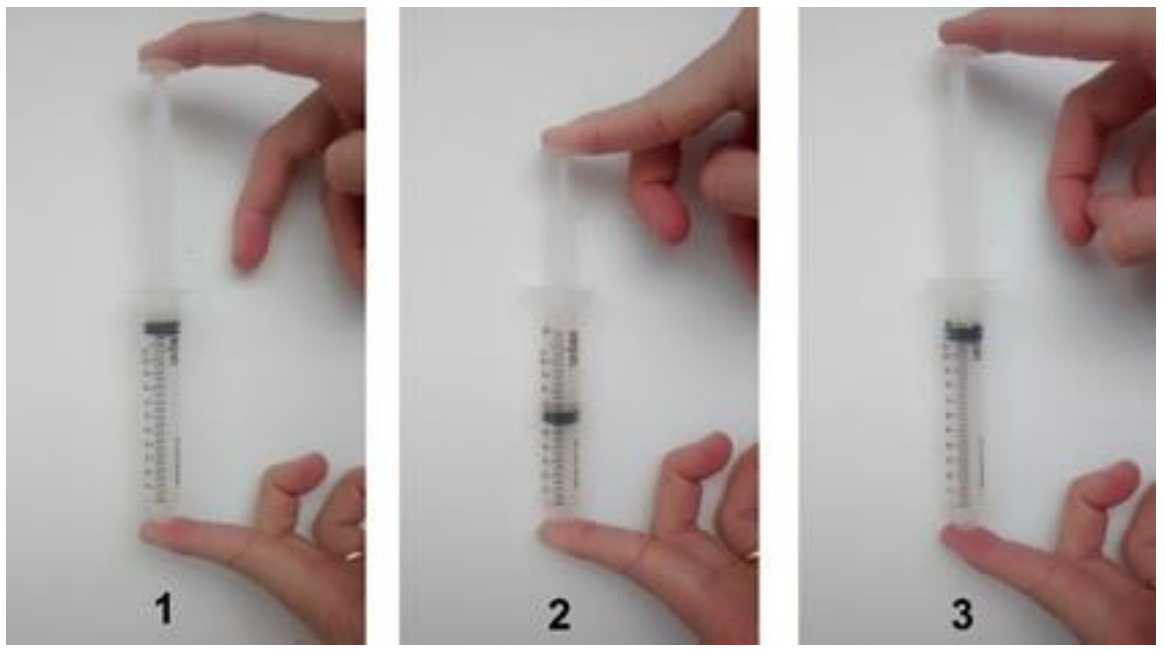

Fonte: do autor 
Como observações macroscópicas será observado que após soltar o êmbolo, ele se move voltando ao estado inicial.

Como interpretações submicroscópicas é explicado que com o aumento da pressão exercida sobre o êmbolo, o ar é comprimido e diminuem os espaços vazios entre as moléculas, que são os constituintes das substâncias presentes no ar acarretando em um aumento da pressão interna do sistema. Quando o êmbolo é solto, a pressão interna maior que a pressão externa empurra o êmbolo e o ar expande voltando ao estado inicial. É importante que nessa explicação os conceitos sejam abordados usando o sistema conceitual.

Para representar o fenômeno observado, estudantes deverão elaborar modelos por meio de desenhos. Cada aluno deverá fazer três desenhos de seringas indicando a posição do êmbolo: um antes da compressão, outro com o êmbolo comprimindo o ar e o terceiro após a soltura do êmbolo. Deve ser solicitado que os alunos desenhem os constituintes das substâncias dentro dessas seringas utilizando o modelo de Dalton modificado. Um modelo de atividade é apresentado no Apêndice A. Enquanto os estudantes estiverem desenhando, sugerimos que sejam observados os seguintes aspectos nas representações:

$\checkmark$ Os estudantes fizeram as representações utilizando o modelo de Dalton modificado?

$\checkmark$ Os estudantes estão representando a mesma quantidade de constituintes durante todo o processo?

$\checkmark$ Eles estão representando os constituintes mais próximos uns dos outros durante a compressão, quando comparados ao estado inicial e final?

Caso algumas dessas respostas sejam negativas, deve-se dialogar com cada estudante relembrando as ideias propostas pelo modelo de Dalton modificado, pedir que ele conte as entidades que desenhou e questionando o porquê de ter desenhado mais moléculas (ou menos moléculas) de forma a dialogar, mostrando a necessidade de se conservar o número de átomos durante todo o processo e também explicar quantas vezes necessário, perguntando ao estudante como ele explica o fato de conseguirmos comprimir o ar, questionando sobre o que acontece com as moléculas. 
A partir desse diálogo deve-se buscar introduzir as concepções científicas a respeito do fenômeno observado. Utilizando o sistema conceitual deve ser explicado que o ar é um material formado por diversas substâncias, e essas substâncias são formadas por um tipo de constituinte, que são as moléculas e que devido a pressão exercida sobre o êmbolo, são diminuídos os espaços vazios entre as moléculas.

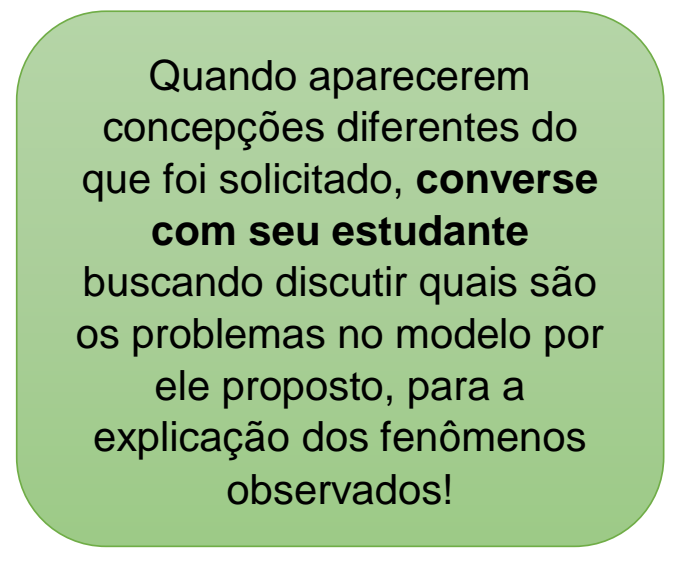

$\mathrm{Na}$ segunda atividade demonstrativo-investigativa é discutido o processo de expansão do ar. Sugerimos que ela seja iniciada com a seguinte pergunta: "É possível encher um balão sem assoprá-lo?". Após ouvir e dialogar sobre as respostas devem ser realizados os seguintes procedimentos: Colocar uma bexiga no gargalo de uma garrafa PET pequena (de água ou refrigerante $600 \mathrm{~mL}$ ) e usando um secador de cabelo soprar ar quente sobre a garrafa por alguns instantes (Figura 7).

Figura 7 - Experimento de expansão do ar em uma garrafa
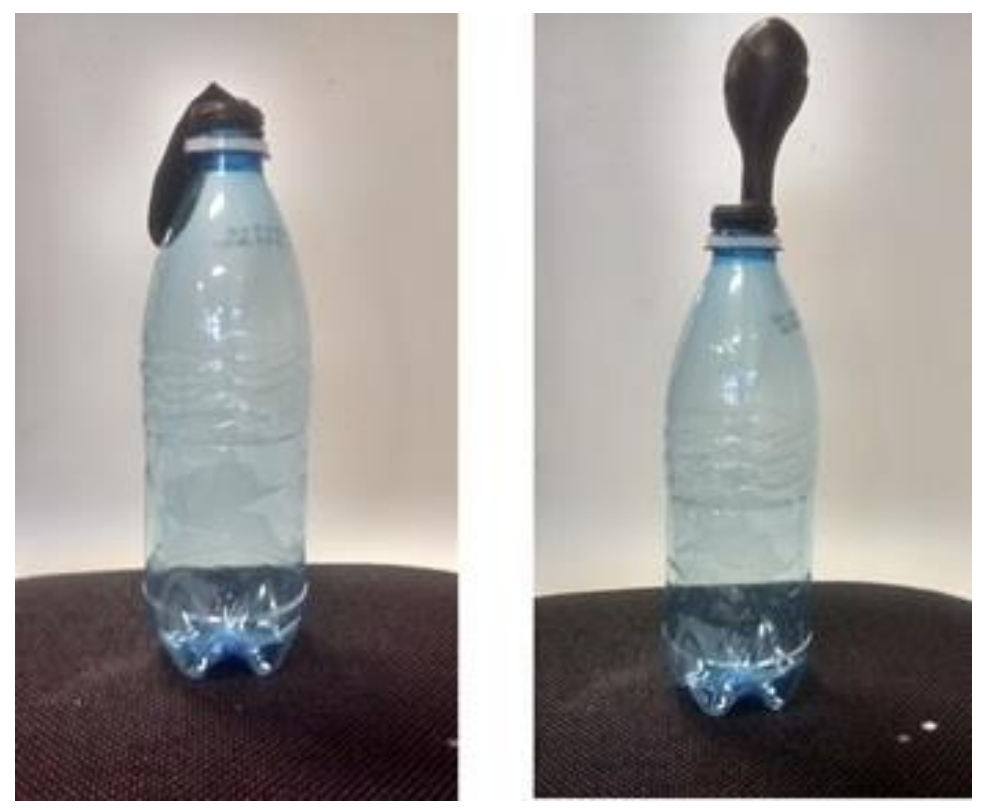

Fonte: do autor

Em nível macroscópico pode ser observado que o balão que estava inicialmente murcho, após soprar ar quente com o secador, enche, conforme pode ser observado na Figura 7. 
Nas interpretações submicroscópicas, sugerimos que os estudantes sejam questionados sobre como a Química explica o fenômeno observado. Como eles já terão observado a atividade de compressão da seringa, analogamente, alguns poderão propor que o balão encheu devido ao aumento dos espaços vazios entre as moléculas presentes nas substâncias acarretando um aumento da pressão interna. $A$ pressão interna maior infla a bexiga até que a pressão interna se iguale a pressão externa. Caso isso não ocorra, deve ser explicado aos estudantes que ao aquecer $\mathrm{o}$ ar dentro da garrafa há um aumento dos espaços vazios entre os constituintes (moléculas) das substâncias presentes no ar.

Deve ficar claro para os estudantes que ocorre um aumento nos espaços entre os

Não utilize o termo partículas ao se referir as moléculas! Os estudantes normalmente entendem partículas como sinônimo de átomos!!! Moléculas são tipos de constituintes presentes nas substâncias! constituintes, pois um problema observado durante este trabalho foi que alguns estudantes, que inicialmente representaram os constituintes das substâncias como moléculas diatômicas, e após o aquecimento, representaram como átomos separados. Em suas explicações, eles diziam que tinha aumentado o espaço entre as partículas! Por isso, recomendamos que seja utilizado o termo molécula ou constituinte, evitando a utilização de partícula.

Para as expressões representacionais, deve ser solicitado que os estudantes representem os constituintes das substâncias presentes no ar dentro da garrafa, antes e após o aquecimento do ar. Novamente, é necessário que sejam observadas as representações dos estudantes, principalmente para os que tiveram uma maior dificuldade na atividade anterior, sendo analisado os aspectos:

$\checkmark$ Os estudantes fizeram as representações utilizando o modelo de Dalton modificado?

$\checkmark$ Os estudantes estão representando a mesma quantidade de constituintes durante todo o processo?

$\checkmark$ Eles estão representando os constituintes mais distantes uns dos outros após o aquecimento do ar?

Quando forem observados algum desses aspectos, deve-se buscar dialogar com os estudantes de modo que eles possam perceber os problemas ou incoerências 
dos modelos propostos e, serem introduzidas as justificativas para o modelo de Dalton modificado ser mais adequado para explicar esse fenômeno. 
Encontro 4: Como representar os constituintes das substâncias utilizando a linguagem química?

\section{Objetivos:}

$\checkmark$ Representar por meio de modelos concretos as moléculas que constituem as substâncias oxigênio, hidrogênio e água, a partir do modelo de Dalton modificado;

$\checkmark$ Escrever a equação química que representa a reação de eletrólise da água a partir dos modelos concretos dos constituintes do gás oxigênio, do gás hidrogênio e da água.

\section{Estratégias didáticas:}

Sugerimos que essa aula seja iniciada com um vídeo que trata da morte de peixes em um rio em decorrência da falta de gás oxigênio na água. Após assistirem ao vídeo, os estudantes devem ser questionados se é possível os peixes morrerem por falta de gás oxigênio na água. Deve ser pedido que os estudantes pensem na resposta a partir do sistema conceitual.

Após ouvir as respostas dos estudantes, deve ser explicado que a água do rio é um material formado por várias substâncias sendo a substância água aquela que está em maior proporção e, dentre elas, está presente o gás oxigênio dissolvido. Assim, o gás oxigênio é uma das substâncias presentes na água. Desta forma, a poluição presente no rio leva a um aumento da matéria orgânica que também consome a substância oxigênio presente na água, levando a diminuição na concentração dessa substância e, consequentemente, a morte dos peixes que precisam dele para respirar.

Retomando as aulas anteriores, deve ser explicado quais são os constituintes das substâncias oxigênio, da substância água, presentes na água do rio.

A partir dessa conversa deve ser realizada uma atividade demonstrativoinvestigativa. Para isso deverá ser obtido construído um sistema de eletrólise semelhante ao da Figura a seguir.

Para isso, são necessários os seguintes materiais: 
D Duas seringas de 10 ou $12 \mathrm{~mL}$, sem as agulhas;

$>$ Dois pedaços de fios de resistência de chuveiro (com aproximadamente $10 \mathrm{~cm}$ de comprimento cada);

> Um recipiente de plástico transparente de $500 \mathrm{~mL}$;

$>$ Dois pedaços de fios com dois pares de garras-jacaré nas pontas;

$>$ Uma bateria $9 \mathrm{v}$.

$>$ Solução $5 \%$ de sulfato de sódio (vendido em farmácias como sal de Glauber); ou solução $5 \%$ de sulfato de magnésio (vendido em farmácias como sal amargo ou sal de Epson);

Não deve ser utilizado cloreto de sódio $(\mathrm{NaCl})$, pois com este sal os produtos obtidos serão 0 gás hidrogênio e o cloro!

Para a montagem do sistema de eletrólise, primeiramente deve ser colocado um pedaço de fio de resistência de chuveiro nas pontas das seringas (onde as agulhas são colocadas), deixando um pequeno pedaço para fora (uns $2 \mathrm{~cm}$ acima da ponta) e a maior parte dentro da seringa. Os fios devem ser colados nessa posição e essas pontas devem ser vedadas também com cola (Figura 8).

Figura 8 - Equipamento para eletrólise da água

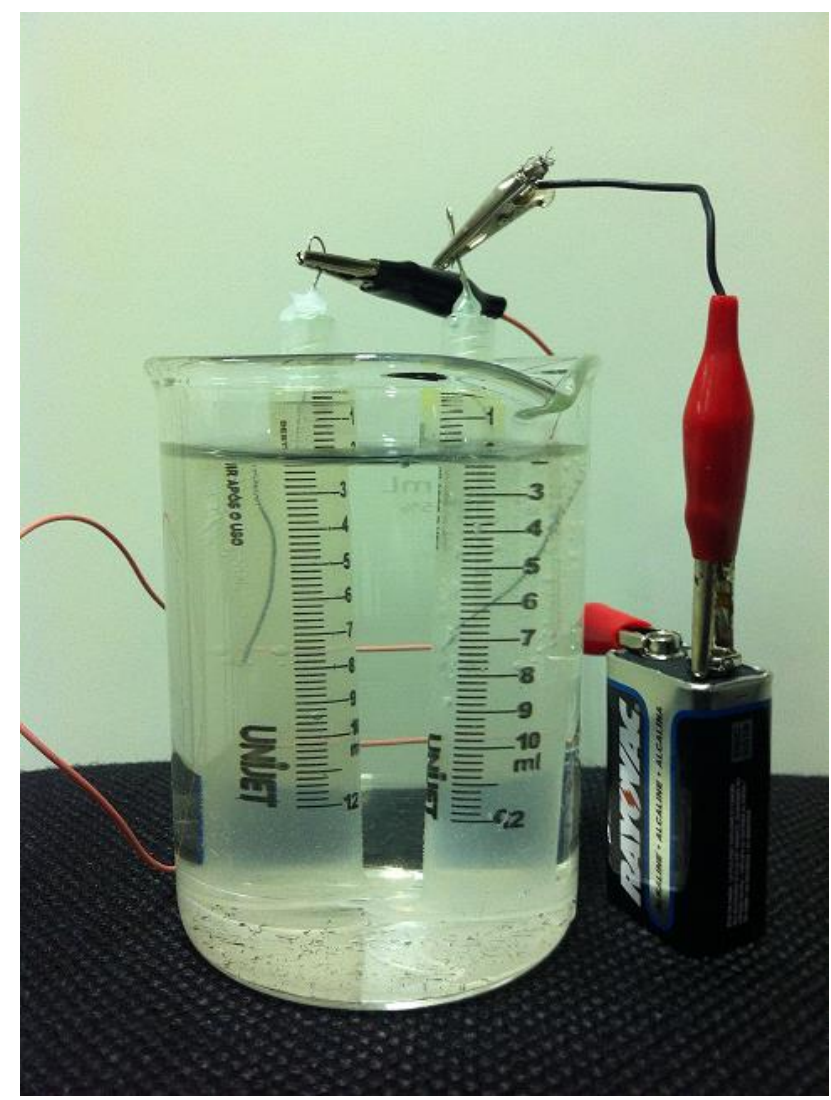

Fonte: do autor 
Dentro de cada seringa deve ser colocada a solução do sal (sulfato de sódio ou sulfato de magnésio) até que fique totalmente cheia. Em seguida, a extremidade mais larga deve ser tapada com o dedo, e a seringa colocada dentro do recipiente com a solução de modo que não entre ar no interior da seringa. Ambas as seringas devem ser colocadas dessa forma, conforme ilustra a Figura. Utilizando os fios com as garrasjacaré, conecte o fio fixado na seringa à bateria. É necessário aguardar alguns minutos.

Como observações macroscópicas será observada a formação de bolhas no interior das seringas. Depois de mais algum tempo, será observada a formação de um volume maior de um gás em uma seringa e de um volume menor de gás na outra. Deverá ser perguntado aos estudantes o que são as bolhas que estão sendo formadas e o que explica a formação dos diferentes volumes de gases nos tubos.

Depois de discutir a respeito das respostas dos estudantes, nas interpretações submicroscópicas deverá ser explicado que esse processo observado é chamado de eletrólise da água. Essa reação química é feita aplicando uma corrente elétrica em uma solução aquosa contendo íons. Quando os eletrodos são conectados a uma fonte de energia (bateria), a substância água é decomposta em outras duas substâncias, que são o gás oxigênio e o gás hidrogênio. É formado um volume maior de gás hidrogênio do que de gás oxigênio em decorrência da proporção maior de átomos de hidrogênio presentes nos constituintes da substância água, que levam a formação de mais gás hidrogênio do que gás oxigênio.

Para as expressões representacionais, deve ser entregue massinhas de modelar aos estudantes solicitando que eles representem os constituintes das substâncias envolvidas: água, oxigênio e hidrogênio, segundo o modelo de Dalton modificado. Os estudantes que conseguirem construir essa representação com facilidade devem ser indagados sobre como seria possível um átomo de oxigênio, presente em uma molécula de água, após a reação resultar na formação do constituinte do gás oxigênio, que contém dois átomos de oxigênio. Eles devem refletir sobre essa questão observando os modelos construídos e os volumes dos gases formados.

Quando os estudantes terminarem de construir os modelos deve ser explicado que na Química são utilizados símbolos para representar os constituintes das substâncias, sendo estes compostos por letras e números e são chamados de fórmulas químicas. Os estudantes podem ser indagados sobre qual letra é utilizada 
para representar os átomos de oxigênio e hidrogênio presentes nos constituintes das substâncias oxigênio, hidrogênio e água. Deve ser explicado que, para representar o número de átomos presentes em cada constituinte, é utilizado o índice, que são os números que aparecem subescritos (um pouco abaixo da letra que representa o átomo). A partir dessa explicação e observando os modelos, deve ser solicitado que os estudantes representem as fórmulas químicas dos constituintes das substâncias envolvidas na reação observada.

Após os estudantes escreverem as fórmulas químicas, deve ser introduzida a ideia de equação química. Para isso deve ser solicitado que os estudantes coloquem os modelos que representam os constituintes das substâncias que estão presentes antes da reação do lado esquerdo e, os que aparecem após a reação do lado direito. Deve ser explicado que na equação química esses constituintes são representados por suas fórmulas químicas, sendo as substâncias que reagem, chamadas de reagentes, representadas do lado esquerdo, e as substâncias formadas, denominadas produtos, do lado direito, e que os reagentes são normalmente separados dos produtos por uma seta. Para separar as substâncias também é utilizado o sinal +. Deve ser solicitado aos estudantes escrevam a equação química que representa a reação química observada.

Em seguida, é importante explicar que na equação química, ao lado das fórmulas químicas que representam os constituintes das substâncias, deve ser especificado o estado físico de cada uma delas, sendo utilizados os símbolos (g) para gasoso, (I) para líquido, (s) para sólido e (aq) para substâncias em solução aquosa. Deve ser solicitado que os estudantes escrevam novamente a equação química que representa a reação observada, representando os estados físicos das substâncias.

Por fim, os estudantes devem observar os modelos concretos e as equações químicas. A partir dessas expressões representacionais, deve-se questionar os alunos sobre a quantidade de átomos de oxigênio nos constituintes das substâncias presentes nos reagentes e nos produtos ressaltando que os átomos não podem surgir do nada. Depois de ouvir as respostas e discuti-las deve ser explicado que a reação observada ocorre em uma proporção definida: duas moléculas de água são necessárias para formação de uma de oxigênio e duas de hidrogênio. Isso justifica a formação de um volume maior de gás hidrogênio do que de gás oxigênio. Deve ser explicado que essa proporção de cada um dos constituintes da reação é indicada na frente da fórmula de cada constituinte. E, para finalizar, os estudantes devem 
representar a equação química indicando a proporção de cada um dos constituintes da substância na reação observada. 


\section{Considerações Finais}

Caro professor (a), a partir das ideias discutidas nesse módulo didático é mostrada uma forma de abordagem dos três níveis do conhecimento químico a partir do uso de sistemas conceituais para o tema gases.

É necessário que após a aplicação dessa proposta você busque abordar os conceitos químicos dentro de sistemas conceituais, discutindo cada um desses três níveis: o nível macroscópico, a partir da discussão de fenômenos; o submicroscópico, apresentando as teorias que explicam os fenômenos apresentados; e o representacional, entendendo que a linguagem química, apesar de ser bastante familiar para você, algumas vezes não é compreendida pelos estudantes e, por isso, deve ser explicado de forma detalhada.

Assim, esperamos que você continue pensando em aulas que possibilitem a discussão desses três níveis do conhecimento químico, seja utilizando atividades demonstrativo-investigativas ou outras estratégias que forem mais adequadas para seu contexto. E também, nas explicações aborde os conceitos na forma de conceitos científicos, ou seja, dentro de sistemas hierárquicos de inter-relações. 


\section{Referências Bibliográficas}

GILBERT, J.; TREAGUST, D. Introduction: Macro, Submicro and Symbolic Representations and the Relationship Between Them: Key Models in Chemical Education. In: GILBERT, J. e TREAGUST, D. (Ed.). Multiple Representations in Chemical Education: Springer Netherlands, v.4, 2009. cap. 1, p.1-8. (Models and Modeling in Science Education). ISBN 978-1-4020-8871-1.

JOHNSTONE, A. H. Chemical education research in Glasgow in perspective.

Chemistry Education Research and Practice, v. 7, n. 2, p. 49-63, 2006. ISSN 1109-4028. Disponível em: < http://dx.doi.org/10.1039/B5RP90021B >.

JOHNSTONE, A. H. Macro and Microchemistry. The School Science Review, v. 64, n. 227, p. 377-379, 1982.

. You Can't Get There from Here. Journal of Chemical Education, v. 87, n. 1, p. 22-29, 2010/01/01 2009. ISSN 0021-9584. Disponível em: < http://dx.doi.org/10.1021/ed800026d >. Acesso em: 2014/07/11.

JUSTI, R. Modelos e Modelagem no Ensino de Química: Um olhar sobre aspectos essenciais pouco discutidos. In: SANTOS, W. L. P. D. e MALDANER, O. A. (Ed.). Ensino de Química em Foco. ljuí, RS: Unijuí, 2011. cap. 8, p.209-230.

JUSTI, R.; GILBERT, J. Teachers' views on the nature of models. International Journal of Science Education, v. 25, n. 11, p. 1369-1386, 2003/11/01 2003. ISSN 0950-0693. Disponível em: < http://dx.doi.org/10.1080/0950069032000070324 >. Acesso em: 2015/05/31.

JUSTI, R. S.; GILBERT, J. K. Modelling, teachers' views on the nature of modelling, and implications for the education of modellers. International Journal of Science Education, v. 24, n. 4, p. 369-387, 2002/04/01 2002. ISSN 0950-0693. Disponível em: < http://dx.doi.org/10.1080/09500690110110142 >. Acesso em: 2014/07/11.

MENDONÇA, P. C. C. Influência de atividades de modelagem na qualidade dos argumentos de estudantes de Química do Ensino Médio. 2011. 272. (Doutorado em Educação). Faculdade de Educação, Universidade Federal de Minas Gerais, Belo Horizonte-MG.

SILVA, R. R.; MACHADO, P. F. L.; TUNES, E. Experimentar Sem Medo de Errar. Ensino de Química em Foco. SANTOS, W. L. P. D. e MALDANER, O. A. Injuí: Injuí: 231-261 p. 2011.

SILVA, R. R. D.; ROCHA-FILHO, R. C.; TUNES, E.; TOLENTINO, M. Ensino de conceitos em Química. II. Matéria: um sistema conceitual quanto à sua forma de apresentação. Ciência e Cultura, v. 38, n. 12, p. 2028-2030, 1986.

SILVA, R. R. S.; ROCHA-FILHO, R. C.; TUNES, E.; TOLENTINO, M. Ensino de conceitos em Química. II. Matéria: Um sistema conceitual quanto à sua forma de apresentação. Ciência e Cultura, v. 38, n. 12, p. 2028-2030, 1986.

TUNES, E.; CARNEIRO, M. H. S.; POLONIA, A. C.; SILVA, A. A.; SILVA, M. S.; BRANDÃO, S. A. Desenvolvimento e Aprendizagem. In: (Ed.). Curso de Pedagogia para professores em exercício no início de escolarização - PIE: Eixo integrador 
: Escola como Instituição Social. Brasília: Faculdade de Educação - UnB, v.Módulo IV, 2002. p.222.

TUNES, E.; TOLENTINO, M.; SILVA, R. R.; SOUSA, E. C. P. D.; ROCHA-FILHO, R. C. Ensino de conceitos em Química. IV. Sobre a estrutura elementar da matéria. Química Nova, v. 12, n. 2, p. 199-202, 1989.

VYGOTSKY, L. S. A construção do pensamento e da linguagem. São Paulo: Martins Fontes, 2001. 